\author{
UNIVERSIDADE DE SÃo PAULO \\ FACUldAdE DE FILOSOFIA, LETRAS E CIÊNCIAS HumanAS \\ DEPARTAMENTO DE LETRAS CláSSICAS E VERNÁCULAS \\ PROGRAMA DE PÓS-GRAdUAÇÃo EM LITERATURA BRASILEIRA
}

Lúcia Carolina Amante Aidar da Silva Telles

\title{
Movimento em construção \\ Correspondência entre Paulo Emílio Sales Gomes \\ e Décio de Almeida Prado, de junho a agosto de 1935
}

VERSÃO CORRIGIDA

O EXEMPLAR ORIGINAL ENCONTRA-SE DISPONÍVEL NO CENTRO DE APOIO À PESQUISA HISTÓRICA (CAPH) DA FFLCH

São Paulo 


\author{
UNIVERSIDADE DE SÃo PAULO \\ FACULDADE DE Filosofia, LETRAS E CIÊNCIAS Humanas \\ DEPARTAMENTO DE LETRAS CláSSICAS E VERNÁCULAS \\ Programa DE PÓS-GRAdUAÇÃo EM LITERATURA BRASILEIRA
}

\title{
Movimento em construção
}

\section{Correspondência entre Paulo Emílio Sales Gomes}

e Décio de Almeida Prado, de junho a agosto de 1935

\author{
Dissertação de mestrado apresentada ao \\ Programa de Literatura Brasileira do \\ Departamento de Letras Clássicas e Vernáculas \\ da Faculdade de Filosofia, Letras e Ciências \\ Humanas da Universidade de São Paulo.
}

Orientador: Prof. Dr. Marcos Antonio de Moraes

VERSÃO CORRIGIDA

O EXEMPLAR ORIGINAL ENCONTRA-SE DISPONÍVEL NO CENTRO DE APOIO À PESQUISA HISTÓRICA (CAPH) DA FFLCH

São Paulo 
Para minha filha Marina, que nasceu durante esse trabalho. 
Ao Prof. Dr. Marcos Antonio de Moraes, pela orientação generosa e tranquila.

Aos Profs. Drs. Marisa Lajolo e Augusto Massi, pelas importantes sugestões no exame de qualificação.

Ao Adilson, Gabriela, Viviane, Olga e Daniel, da Cinemateca Brasileira, pelas ajudas preciosas. À minha avó Lygia, pela casa, biblioteca, computador, acervo e lindas conversas.

A Regina, Paula e Aline, pelo auxílio na dissertação.

A Nara, Sueli, Lídia e Maria, que cuidaram do cotidiano.

Aos meus pais Cida, Moisés e Goffredo, pela inspiração e companheirismo constante.

Ao Renato, por tudo, sempre. 
"As primeiras notícias dos 'viajantes' vieram numa carta do Ega para o Vilaça, de Nova Iorque. Era curta, toda de negócios. Mas ele ajuntava um pós-escrito com o título de Informações gerais para os amigos".

Eça de Queiroz 


\section{Resumo}

Esta dissertação apresenta e estuda a correspondência inédita trocada, na juventude, entre Paulo Emílio Sales Gomes (1916-1977) e Décio de Almeida Prado (1917-2000), no período de junho a agosto de 1935, vinculada à publicação do único número de Movimento - revista do presente que enxerga o futuro. As 19 cartas transcritas e anotadas, pertencentes ao Arquivo Paulo Emílio Sales Gomes (APESG), da Cinemateca Brasileira, em São Paulo, fornecem elementos biográficos para se compreender aspectos da formação intelectual e política de dois críticos de grande projeção no campo cultural e universitário, bem como subsídios para o estudo da sociabilidade literária e do periodismo no Brasil. Buscou-se recuperar documentos de época, como artigos e testemunhos dos correspondentes e de outras personalidades citadas nas cartas.

Palavras-chave: Correspondência, Paulo Emílio Sales Gomes, Décio de Almeida Prado, Movimento, sociabilidade intelectual. 


\begin{abstract}
The present dissertation presents and studies the unpublished correspondence, exchanged between Paulo Emílio Sales Gomes (1916-1977) and Décio de Almeida Prado (1917-2000), in their youth, from June to August 1935, pertaining to the unique edition of Movimento - revista do presente que enxerga o futuro. The 19 transcribed and commented letters are part of the Arquivo Paulo Emílio Sales Gomes (APESG), of the Cinemateca Brasileira in São Paulo. They provide biographic elements to understand aspects of the intellectual and political background of two critics of great prominence in the cultural and university fields, as well as information to study the literary and journalistic sociability in Brazil. We sought to recover original documents from the period, such as articles and testimonials from the correspondents themselves and from other personalities mentioned in the letters.
\end{abstract}

Key-words: Correspondence, Paulo Emílio Sales Gomes, Décio de Almeida Prado, Movimento, intellectual sociability. 


\section{Sumário}

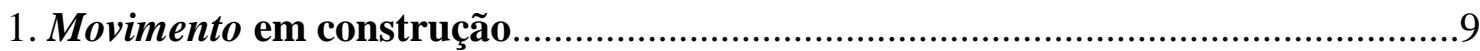

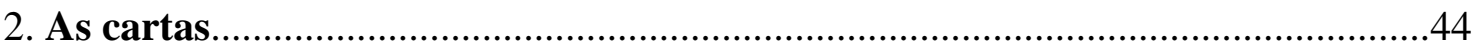

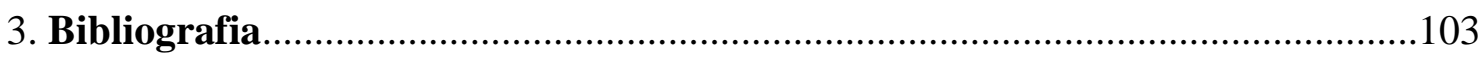

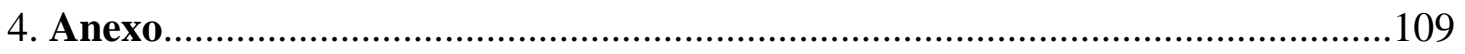




\section{Movimento em construção}

\section{Dezenove cartas e uma revista}

Movimento - revista do presente que enxerga o futuro, tirada do prelo, em São Paulo, em julho de 1935, testemunha a formação intelectual de Paulo Emílio Sales Gomes (1916-1977) e Décio de Almeida Prado (1917-2000). Esta dissertação tem por finalidade apresentar e estudar a correspondência trocada entre os dois amigos, no período de junho a 21 de agosto de 1935, vinculada ao trabalho de edição do primeiro e único número da revista. Tem, assim, como eixo central, 19 cartas (correspondência ativa e passiva), sendo onze assinadas por Paulo Emílio Sales Gomes e oito por Décio de Almeida Prado, documentação depositada e catalogada no Arquivo Paulo Emílio Sales Gomes (APESG), na Cinemateca Brasileira, em São Paulo. Reconstituir, por meio dessa correspondência, a trajetória desses dois críticos e a elaboração da revista, pode contribuir também para a compreensão de projetos futuros dos interlocutores, como a revista Clima, por exemplo. Como eixo secundário, a pesquisa tenciona apreender aspectos da rede de sociabilidade construída pelos carteadores, bem como a história da elaboração, difusão e recepção do periódico paulistano.

A publicação da revista de cultura representou importante tentativa de um grupo de jovens críticos em dialogar com a geração anterior que havia concebido a Semana de Arte Moderna, em fevereiro de 1922. Favoreceu a continuidade das trilhas artísticas e ideológicas abertas pelo modernismo. Trazendo capa de Anita Malfatti e textos de Mário de Andrade, Flávio de Carvalho, Lúcia Miguel Pereira, Paulo Emílio Sales Gomes, Décio de Almeida Prado, entre outros, Movimento, deixa claro, no manifesto escrito por Paulo Emílio, a proposta de abertura de interlocução crítica: "Nós precisamos avançar e ocupar os postos para os quais estamos sendo chamados por uma necessidade social de novas energias". O desejo de identificar uma geração nova de intelectuais presentifica-se na correspondência. Em 10 de agosto de 1935, Décio escreve a Paulo Emílio, tecendo críticas às colaborações dos jovens na revista: "Perdoe-me a indiscrição, mas quais são os componentes dessa famosa geração dos 'novíssimos' tão falada em entrevistas e de quem o Oswald gosta tanto?"1

\footnotetext{
${ }^{1}$ Arquivo Paulo Emílio Sales Gomes/Cinemateca Brasileira, PE/CP 0044.
} 
O debate nascido na correspondência contribui para se documentar a configuração da revista, em sua face literária e política, assim como os caminhos percorridos por esses jovens na busca por um lugar de destaque no campo intelectual brasileiro. As cartas, ao registrar leituras partilhadas, perspectivas críticas transmitidas nos textos produzidos e discussões, fornecem elementos para que se compreenda a formação do grupo que Oswald de Andrade chamou de "os chato-boys", geração que "lê desde os três anos. Aos 20 tem Spengler no intestino. E perde cada coisa!"."

\section{"Quanto aos comentadores de nossa correspondência é preciso que deixemos dispositivo sobre isso" ${ }^{3}$}

Em 1935, após Décio de Almeida Prado abandonar os estudos que o direcionavam para a Faculdade de Medicina, foi aconselhado por seu pai a passar uns meses em Campos do Jordão, a fim de recobrar a saúde e se preparar para o novo vestibular, agora para a Faculdade de Filosofia da Universidade de São Paulo. Dessa distância geográfica (Décio em Campos do Jordão e Paulo Emílio em São Paulo) nascem essas cartas que documentam os trabalhos de edição da revista Movimento, podendo, desse modo, ser consideradas um "diário da obra", expressão utilizada por José-Luis Diaz em seu artigo “Qual genética para as correspondências?”.

As mensagens trocadas entre os dois jovens, com 17 e 18 anos, podem ser vistas igualmente como "arquivo da criação", ou seja, "o espaço onde se encontram fixadas as gêneses e as diversas etapas de elaboração de uma obra artística [no caso, uma revista de cultura], desde o embrião do projeto até o debate sobre a recepção crítica favorecendo a sua eventual reelaboração". 5 As fases de constituição de Movimento, espelhadas nas cartas, mostram igualmente que "a troca de opinião sobre trabalhos em desenvolvimento fundamenta os passos da criação, muitas vezes vista como ação compartilhada". 6

A pesquisa em cartas, documentos da vida privada, demanda questionamentos prévios. Philippe Lejeune em “A quem pertence uma carta?” aborda questões éticas e

\footnotetext{
${ }^{2}$ ANDRADE, Oswald. "Bilhete sobre fantasia". Revista Clima. São Paulo, n. 5, outubro de 1941.

${ }^{3}$ Arquivo Paulo Emílio Sales Gomes/Cinemateca Brasileira, PE/CA 0458.

${ }^{4}$ DIAZ, José-Luis. "Qual genética para as correspondências?". Tradução de Cláudio Hiro e Maria Silvia Ianni Barsalini. Manuscrítica - Revista de crítica genética, n. 15, 2007, p. 124.

${ }^{5}$ MORAES, Marcos Antonio de. "Epistolografia e crítica genética". Ciência e cultura (SBPC), v. 59, n. 1. São Paulo, Jan./Mar. 2007, p. 30-2.

${ }^{6}$ Ibidem.
} 
patrimoniais relacionadas à difusão de correspondências. O pesquisador francês, estudioso das escritas de si, lembra que "por definição, a carta é uma partilha. Ela tem diversas faces: é um objeto (que se troca), um ato (que coloca em cena o 'eu', o 'ele' e os outros), um texto (que se pode publicar)". ${ }^{7} \mathrm{O}$ desvelamento das cartas estudadas nesta dissertação, colocando "em cena" (espaço público) os carteadores e outras personalidades por eles mencionadas, justifica-se na medida em que fornece elementos biográficos para o estudo de dois importantes nomes da cultura brasileira, tanto quanto possibilita compreender momentos da história intelectual do país, no que tange a estratégias de difusão de um periódico. Embora Movimento não tenha obtido grande projeção, nem continuidade, configurou-se como momento essencial na formação crítica de Paulo Emílio Sales Gomes e Décio de Almeida Prado. Cabe lembrar que Almuth Grésillon, em Elementos de crítica genética, afirma que, pelo "valor simbólico e patrimonial", as correspondências "merecem não somente conservação, mas também exploração". 8

Como escritos únicos, precários, não destinados à publicação, as cartas dependem do interesse de seus interlocutores em preservá-los. O arquivo Paulo Emílio Sales Gomes (APESG), da Cinemateca Brasileira, abriga em torno de 25.000 documentos e foi doado por Lygia Fagundes Telles (viúva de Paulo Emílio) em 1978, um ano após a morte do crítico. Ao longo do tempo, outros documentos foram também sendo doados por amigos e familiares do crítico, entre os quais o conjunto de cartas remetidas a Décio de Almeida Prado, complementando o arquivo. Além de textos, livros, cartazes, fotografias, o arquivo conta com a Série Correspondência, com aproximadamente 2.700 cartas, que vão de 1930 a 1976, testemunhando, de modo muito produtivo, a trajetória de Paulo Emílio. No ano de 2004, esses documentos, graças ao auxílio proveniente da ADAI (Ayuda al Desarrollo de lós Archivos Iberoamericanos) do Ministério da Cultura da Espanha, através do Conselho Nacional de Arquivos, começaram a ser catalogados, armazenados e descritos analiticamente por uma equipe capacitada que, até os dias de hoje, trabalha com grande envolvimento na preservação e divulgação do arquivo do fundador da casa.

\footnotetext{
7 Apud MORAES, Marcos Antonio de. "Sobrescrito". Teresa revista de literatura brasileira 8/9. Programa de Pós-graduação em Literatura Brasileira, DLCV-FFLCH-USP, 2008, p. 8.

8 GRÉSILLON, Almuth. "Objetivos e finalidades". Elementos de crítica genética. Ler os manuscritos modernos. Tradução de Cristina de Campos Velho Birck, Letícia Cobalchini, Simone Nunes Reis e Vincent Leclerq. Porto Alegre: Editora da UFRGS, 2007, p. 28-9.
} 
Cabe assinalar que a correspondência entre os dois críticos é continua, contandose diálogos mais frequentes na época de Movimento, no período em que Paulo Emílio esteve preso nos presídios do Paraíso e do Maria Zélia, em São Paulo (dezembro de 1935 a fevereiro de 1937), nas duas temporadas de Paulo Emílio na França (a primeira, de maio de 1937 a dezembro de 1939; a segunda, de abril de 1946 a maio de 1954) e durante as viagens dos interlocutores a trabalho.

Enquanto documentos autógrafos e datiloscritos, as cartas exigem o trabalho de decifração e transcrição, trabalho minucioso, árduo, considerando-se a caligrafia irregular de Paulo Emílio. Trata-se do esforço de tornar o documento legível, buscandose um texto fidedigno, para ser explorado em bases críticas consistentes. Sobre essa atividade, escreveu Louis Hay em A literatura dos escritores - Questões de crítica genética: "E agora, como fazê-lo [o manuscrito] falar? Primeiramente, decifrando seu texto: a mensagem que seus apontamentos nos transmitem são sua razão de ser, compreendê-los é dispor de seu sentido". 9

No trabalho de edição de uma correspondência, conta-se ainda a atividade de anotação, considerando o caráter elíptico dessas mensagens. E que tipo de nota de pesquisa seria pertinente para as cartas estudadas nesta dissertação? Colette Becker, em "O discurso de escolta: a anotação e seus problemas (a propósito da correspondência de Zola)", tratando dos tipos de notas possíveis em uma edição crítica sugere caminhos fecundos:

Toda edição crítica comporta dois tipos de notas: notas puramente descritivas e notas que eu chamaria de 'explicativas'[...]. Eu gostaria de me deter no segundo tipo de notas, em que o editor [...] faz-se comentador, mesmo autor, isto é, as notas que visam, segundo a expressão tradicional, 'esclarecer' o texto. [...] Acontece que o editor escolhe fazer esta ou aquela nota [...]. Poderíamos avançar ainda mais. Afirmar simplesmente que toda nota dita 'explicativa' é, em graus muito variáveis, sempre interpretativa. ${ }^{10}$

\footnotetext{
${ }^{9}$ HAY, Louis. "Os manuscritos no laboratório". A literatura dos escritores: questões de crítica genética. Tradução de Cleonice Paes Barreto Mourão. Belo Horizonte: Editora UFMG, 2007, p. 299.

10 BECKER, Colette. "O discurso de escolta: a anotação e seus problemas (a propósito da correspondência de Zola)". (Tradução de Claudio Hiro para uso didático na disciplina Epistolografia do Modernismo Brasileiro (IEB-USP), ministrada pelo Prof. Marcos Antonio de Moraes. "Le discours d'escorte: l'annotation et ses problèms (à propos de la correspondance de Zola): In: Les correspondances inédites. Textos reunidos por André Françon e Claude Goyard. Paris: Econômica, 1984).
} 
Nesses termos, o trabalho de anotação das cartas de Paulo Emílio e Décio se propôs a reconstituir a ambiência intelectual do período, recuperar a rede de relações intelectuais e de amizade.

\section{"uma carta no sentido ilimitado em que eu, você e o Mário de Andrade usamos esse termo" $" 11$}

A própria carta surge como assunto nessa correspondência. Em junho de 1935, Décio de Almeida Prado avalia mensagem recebida de Paulo Emílio: "Achei muito interessante a sua carta. Mário de Andrade disse da necessidade dos intelectuais brasileiros se mostrarem em pijama, em suas cartas. Você, sempre exagerado, logo se mostrou em cuecas". ${ }^{12}$ Nesse trecho, fica evidente o valor que os interlocutores atribuem à correspondência como espaço de debate intelectual, construído no âmbito da amizade. Assim, nela, é recorrente a discussão sobre literatura, política, evidenciando experiências no debate cultural e ideológico, tanto quanto a troca de experiências pessoais. Em agosto desse ano, Paulo Emílio escreve a Décio, em tom galhofeiro: "A propósito, se você me mandar mais um provérbio em suas cartas eu lhe escrevo uma que não poderá entrar para nossa 'correspondência completa"..13

O valor atribuído à correspondência, balizando-se pela extensa e intensa produção epistolar do escritor modernista Mário de Andrade, verifica-se em outros momentos da vida intelectual de Paulo Emílio Sales Gomes e Décio de Almeida Prado. Em 1957, por exemplo, Paulo Emílio, no "Suplemento Literário" d'O Estado de $S$. Paulo (para o qual escreveu entre os anos de 1956 e 1965), ao tratar da Film Library em Nova Iorque, refere-se à correspondência de Ezra Pound. ${ }^{14}$ Em 1963, no artigo "Chaplin melhor pior", explicita esse gosto pela escrita de cartas:

[...] eu resolvi escrever duas cartas tendo como destinatários Trotski e Chaplin. Não conhecia e não conheci nenhum dos dois mas eles eram os únicos contemporâneos ilustres a quem tive vontade de dizer alguma coisa naquele momento em que a guerra perturbava minhas

\footnotetext{
${ }^{11}$ Arquivo Paulo Emílio Sales Gomes/Cinemateca Brasileira, PE/CA 0457.

12 Arquivo Paulo Emílio Sales Gomes/Cinemateca Brasileira, PE/CP 0037.

${ }^{13}$ Arquivo Paulo Emílio Sales Gomes/Cinemateca Brasileira, PE/CA 0460.

${ }^{14}$ GOMES, Paulo Emílio Sales. "Relatório da Film Library". Crítica de cinema no Suplemento Literário, v. 1. Rio de Janeiro: Paz e Terra, 1981, p. 58. "Na correspondência de Ezra Pound encontram-se várias cartas escritas em 1916-17 para uma moça inglesa que se preparava para seguir a carreira literária [...]”.
} 
perspectivas e atrapalhava meus projetos. Não seria fácil reconstituir hoje essas perspectivas e projetos ou as cartas que imaginei. Deveriam certamente incluir meditações e cálculos a respeito da morte da civilização e das chances de uma nova cultura [...]. Não cheguei sequer a escrever as cartas, em parte por causa das namoradas que decididamente também têm ocupado espaço em minha vida. ${ }^{15}$

Pesquisador de cinema, também lançou mão de cartas na extensa pesquisa para a produção do estudo sobre o cineasta francês Jean Vigo. ${ }^{16}$

Sobre as cartas do período em que Paulo Emílio esteve preso - muitas delas censuradas - Décio de Almeida Prado, em “Paulo Emílio na prisão", de 1984, historia:

Em junho de 1936 Paulo Emílio escreveu-me uma carta que só agora, dezembro de 1984, chega às minhas mãos. Esse escandaloso atraso, esse atraso histórico de quase cinquenta anos, que me deu por alguns minutos a sensação de ter voltado à adolescência, encerra uma história que merece ser contada. ${ }^{17}$

\section{"nos conhecemos bem já" 18}

Paulo Emílio e Décio de Almeida Prado se conheceram ainda meninos, no primeiro ano do Liceu Nacional Rio Branco, em São Paulo, e foram amigos durante toda a vida.

O amor pela literatura e o prazer pela palavra escrita levaram os dois jovens a dirigir jornais e revistas nos tempos escolares e universitários, como é o caso de Movimento. Estudaram juntos na adolescência como vestibulandos para a Escola Paulista de Medicina e logo viram que não teriam futuro na carreira de seus pais, respeitados médicos de São Paulo. Sobre isso Décio conta:

\footnotetext{
${ }^{15}$ CALIL, Carlos Augusto; MACHADO, Maria Teresa (orgs.). "Chaplin melhor pior”. Paulo Emílio: um intelectual na linha de frente. São Paulo: Editora Brasiliense, 1986, p. 241.

${ }^{16}$ A respeito do trabalho de Paulo Emílio sobre Jean Vigo, Décio de Almeida Prado escreveu na orelha de Crítica de cinema no Suplemento Literário: "Mais do que uma biografia, um paciente trabalho de exumação de um criador cinematográfico injustamente esquecido. O êxito imediato da obra, traduzida para o inglês, com edições na Inglaterra e nos Estados Unidos, deu-lhe uma projeção universal como pouquíssimos brasileiros chegaram a ter".

${ }^{17}$ PRADO, Décio de Almeida. "Paulo Emílio na prisão". Seres, coisas, lugares (Do teatro ao futebol). São Paulo: Companhia das Letras, 1997, p. 147.

${ }_{18}$ Arquivo Paulo Emílio Sales Gomes/Cinemateca Brasileira, PE/CA 0460.
} 
Quando nós nos reuníamos para estudar, eram conversas intermináveis, discussões, e eu até desenvolvi um gosto pela caminhada. Porque às vésperas dos exames, quando sentíamos a obrigação de estudar, eu ia para a casa do Paulo Emílio e nós saíamos pelo Pacaembu, que era um ermo, andando, subindo e descendo morros, verdadeiras proezas atléticas, sempre conversando. ${ }^{19}$

Foi frequente na vida dos dois amigos participações em grupos de discussão sobre política, literatura e artes plásticas. O primeiro desses grupos, bastante comentado nas cartas, o "Cassino", era composto de jovens amigos que se reuniam semanalmente na casa da família Sales Gomes para jogar cartas e conversar. Segundo Décio,

éramos todos amigos, unidos por centenas de horas de pôquer diurno e noturno, com um considerável acervo comum, constituído por reminiscências grupais, prosas interrompidas e retomadas, frases de uso coletivo, algumas de sabor propositadamente literário e queirosiano (“Esta vida é uma choldra!"). ${ }^{20}$

O ano de 1935 marca a entrada de Paulo Emílio e Décio na vida literária e intelectual da cidade de São Paulo, ocasião em que se dá o encontro do primeiro deles com a política. Paulo Emílio aproxima-se da Juventude Comunista, participa da conferência no Sindicato dos Ferroviários da Central do Brasil, publica textos no jornal esquerdista A Platéia, filia-se à Aliança Nacional Libertadora, a ANL. No final de 1935, os amigos trazem a lume Movimento, e Paulo, pouco depois de completar 19 anos, é preso e seu crime "reduzia-se ao uso da sua arma principal, a palavra [...]". ${ }^{21}$ Esse período é, portanto, marco fundamental na constituição política e intelectual da geração dos correspondentes. Décio assegurava que "o político, o cabeça pensante do nosso grupo" era Paulo Emílio, "porque ele teve uma atuação política com 18, 19 anos aqui em São Paulo. No fim de 1935, quando fez 19 anos, foi preso". ${ }^{22}$ Para Antonio Candido,

\footnotetext{
${ }^{19}$ SOUZA, José Inácio de Melo. Paulo Emílio no Paraíso. Rio de Janeiro: Record, 2002, p. 18.

20 "Três movimentos (musicais) em torno de 1930". Seres, coisas, lugares (Do teatro ao futebol). Ed. cit., p. 105.

${ }^{21}$ Paulo Emílio no Paraíso. Ed. cit., p. 77.

${ }^{22}$ BERNSTEIN, Ana. A crítica cúmplice - Décio de Almeida Prado e a formação do teatro brasileiro moderno. São Paulo: Instituto Moreira Salles, 2005, p. 297.
} 
foi o mesmo amigo quem os politizou, pois "influenciava essencialmente parecendo apenas sugerir". 23

As referências à formação política de Paulo Emílio e de Décio mostram-se predominantes nas cartas vinculadas à publicação de Movimento. O interesse por Stálin, Trotski, Rússia, ANL, intelectuais brasileiros ligados ao Partido Comunista, como Colbert Malheiros e Osório César, ganha relevo nas mensagens. Cabe lembrar que a geração dos críticos tinha como legado histórico a fundação do Partido Comunista, em 1922, bem como o adensamento no Brasil da polarização esquerda/direita, nos anos de 1930.

Os acontecimentos marcantes desse início da década de 1930, em perspectiva autobiográfica, são retomados por Paulo Emílio, entre 1973 e 1976, ao colocar em marcha a escritura da novela Cemitério, manuscrito que permaneceu inacabado, recebendo edição póstuma em 2007, com texto estabelecido por Carlos Augusto Calil. O narrador, baiano, comentando a relação de Getúlio Vargas com o Brasil, em certo momento avalia:

Os paulistas pensam que o Brasil inteiro tem obrigação de saber o que fazem. Revoluções de antigamente não faltam, a do Padre Cícero, o bombardeio da Bahia por Seabra, a revolução de Isidoro em São Paulo que não foi dos paulistas, a deles é a de 32, que querem impingir para todo mundo. Ninguém teve tanta paciência com os paulistas como o Dr. Getúlio Vargas e se isso não está lhe sendo contado no céu é porque não tem importância e pode ser até que nesse ponto ele tivesse errado. $^{24}$

Mais adiante, o narrador, avaliando os acontecimentos políticos dos anos de 1934 e 1935, desabafa, recuperando aspectos memorialísticos de Paulo Emílio:

Quando em setembro os paulistas perderam, chorei meu primeiro choro impessoal, mas então já descolava a tênue película e ao completar 16 anos e receber de papai o pacote que autorizava a leitura de todo Eça, a vontade de divergir dos colegas do Liceu Nacional Rio Branco da rua [Dr.] Vilanova. Encontrava bons trilhos em conversas

\footnotetext{
${ }^{23}$ CANDIDO, Antonio. Teresina etc. Rio de Janeiro: Ouro sobre Azul, 2007, p. 89.

${ }^{24}$ GOMES, Paulo Emílio Sales. Cemitério. São Paulo: Cosac Naify, 2007, p. 21.
} 
sobre comunismo com Décio de Almeida Prado, que soube da novidade antes de mim, lia Raul de Leoni e ao Eça preferia Machado de Assis. Antes dos 17 anos o Salvador das tias-avós escuras e mumificadas e de Doya, a primeira moça que me quis sem dinheiro, e antes dos 18 a Juventude Comunista recrutado por Décio Pinto de Oliveira, morto na praça da Sé, num domingo à tarde em outubro de 1934, de revólver na mão dando batalha à polícia de Apolônio e aos integralistas. $^{25}$

Nas cartas trocadas em 1935, chama a atenção o interesse dos correspondentes pela extinta URSS e pelos assuntos ligados ao comunismo. Na primeira delas, Décio agradece livros enviados e pede que o amigo receba bem o conhecido de Araraquara "bastante trabalhado pelos camaradas".

As leituras sobre o comunismo eram muito restritas nesse período no Brasil e tudo que aparecia publicado ajudava para ampliar o conhecimento dos jovens. A discussão travada sobre Stálin e Trotski demonstra a tentativa de nomear e entender categorias e figuras políticas da época. O interesse por questões históricas e políticas perdurou nas carreiras profissionais de Paulo Emílio e Décio, como professores e críticos de cinema e teatro. Paulo, nesse sentido, recupera, em "Eisenstein e o herói", artigo de 1958, no "Suplemento Literário" de O Estado de S. Paulo, os anos de 1930:

O culto ao herói individualizado desenvolveu-se na Rússia paralelamente ao poder político de Stálin, o qual atingiu, numa época ainda próxima às monstruosas proporções conhecidas. No meio da década dos trinta, Stálin já era herói máximo glorificado pelos literatos, historiadores, artistas plásticos, dramaturgos e cineastas. As lisonjas a ele dirigidas não tinham limites. ${ }^{26}$

Convidado a participar, em 1945, do inquérito Plataforma da nova geração, promovido pelo escritor e jornalista Mário Neme, Paulo Emílio retoma a importância da década de 1930 para a definição ideológica de sua geração:

\footnotetext{
${ }^{25}$ Cemitério. Ed. cit., p. 34-5.

26 "Eisenstein e o herói”. Crítica de cinema no Suplemento Literário, v. 1. Ed. cit., p. 259.
} 
Os moços que têm hoje pouco menos ou pouco mais de trinta anos, fizeram uma primeira aproximação com as ideias políticas e sociais de nosso tempo, há uns dez anos atrás. No extenso e superficial debate de ideias sociais, literárias, artísticas e científicas (marxismo, psicanálise, pós-modernismo artístico etc.) que acompanhou a vitória da também extensa e superficial revolução de 1930, avultava o interesse em torno da Rússia forjada pela revolução de outubro de $1917 .^{27}$

Em 1961, em "Introdução bastante pessoal”, texto no "Suplemento Literário", Paulo Emílio avalia a sua relação com a Rússia, "o país que mais me interessou e durante mais tempo". Procura justificar-se:

O motivo era político mas eu me pergunto se esta expressão é a mais adequada para resumir o estado de espírito dos jovens brasileiros que abordavam os problemas russos nos anos imediatamente anteriores e posteriores a $1930 .^{28}$

Analisando as cartas de 1935 e os textos divulgados em Movimento pode-se intuir que Paulo Emílio Sales Gomes e Décio de Almeida Prado depositavam esperança na implementação do comunismo como organização política. Essa crença é documentada nas lembranças de Décio:

Comunismo era uma conversa muito frequente, já que um pouco antes de 1930 o famoso Plano Quinquenal tinha causado grande impressão, o plano de eletrificação da Rússia parecia uma coisa extremamente modernizante. O meu pai achava que o comunismo iria vencer, se espalhar pelo mundo inteiro, seria uma coisa talvez penosa para nós, para nossa família, para nossa classe, mas no fundo seria uma coisa mais ou menos justa. ${ }^{29}$

O surgimento da ANL, em março de 1935, deu força ao movimento esquerdista e foi fundamental para a formação política dos carteadores. Décio de Almeida Prado, na

\footnotetext{
${ }^{27}$ NEME, Mário (org.). "Plataforma da nova geração". Plataforma da nova geração. Porto Alegre: Livraria do Globo, 1945, p. 284.

${ }^{28}$ GOMES, Paulo Emílio Sales. "Introdução bastante pessoal". Crítica de cinema no Suplemento Literário, v. 2. São Paulo: Paz e Terra, 1981, p. 357.

${ }^{29}$ Paulo Emílio no Paraíso. Ed. cit., p. 21.
} 
primeira carta desse conjunto, sugere a formação do partido em Araraquara, ajudado pelo amigo Sebastião Leite Ribeiro de Carvalho, que morava naquela cidade. Logo depois, em carta de 5 de julho de 1935, menciona o comício do partido em que o amigo Paulo Emílio teria discursado. Victor de Azevedo explicita a orientação desses discursos:

Os oradores aliancistas se sucediam, nem sempre com ideias
uniformes, mas todos com um ponto de vista comum: a repulsa à
Direita e a ênfase quanto à necessidade inadiável de uma profunda
articulação política em defesa das liberdades democráticas
ameaçadas. $^{30}$

Décio termina a carta referindo-se aos membros importantes da ANL ligados à Juventude Comunista. Sobre a ANL e os grupos que a apoiavam, Paulo Emílio escreveu em 1961:

\begin{abstract}
Entretempo, familiarizara-me um pouco com o movimento anarquista brasileiro lendo A Plebe, editada no Rio, ou A Lanterna, de São Paulo, periódicos de publicação bastante irregular, ou ouvindo oradores em reuniões promovidas pela Aliança Nacional Libertadora, movimento de inspiração comunista ao qual a maior parte dos esquerdistas, inclusive um grupo anarquista, deu o seu apoio. ${ }^{31}$
\end{abstract}

Na carta de 16 de julho de 1935, Paulo Emílio partilha com o amigo os últimos acontecimentos em São Paulo, o "fechamento da aliança" e o "estouro da boiada". Com o fechamento da ANL, em julho de 1935, ordenado por Getúlio Vargas, e as comemorações da Revolução Francesa, a polícia paulistana foi para as ruas reprimir as possíveis manifestações. Ali, depararam-se com um estouro de zebus. As 350 cabeças de bois que vinham de Mato Grosso para serem abatidas em São Paulo, acabaram se dispersando na Estação do Ipiranga. Zulmira Ribeiro Tavares, em seu romance Café pequeno, recria o ambiente dessa São Paulo tomada por manifestações políticas e pelo "estouro da boiada", tecendo ligação entre os dois episódios; em certa passagem do

\footnotetext{
${ }^{30}$ AZEVEDO, Victor de. "Paulo Emílio: preso político". Ensaios de Opinião - Paulo Emílio, v. 6. Rio de Janeiro: Inúbia, 1978, p. 13.

31 "Anarquismo e cinema". Crítica de cinema no Suplemento Literário, v. 2. Ed. cit., p. 383.
} 
romance, uma personagem constata: “[...] eles podiam ter falado zebus, mas queriam dizer arruaceiros". 32

O percurso político desses jovens caracteriza-se pela proposta de construção de um socialismo democrático, ou seja, pela vontade de transformação revolucionária, mas pela luta democrática, afastando-se do stalinismo e do trotskismo. Assim, o grupo, liderado por Paulo Emílio, abria caminho para formas de socialismo ajustadas ao Brasil, deixando um legado ideológico.

A política, entretanto, não era o único interesse desses jovens, nem o único asunto dessas cartas. A vontade de penetração na cena modernista mostrou-se, igualmente, vontade de revolução.

\section{“O Oswald vê em nós [...] o primeiro grupo que está aparecendo depois da turma dele, do Mário" ${ }^{33}$}

Destaca-se nas cartas estudadas o propósito de traçar uma ponte entre Movimento e a geração modernista, que havia deixado uma expressiva contribuição literária e crítica, em livros e efêmeras revistas de cultura (Klaxon, Estética, A Revista, Terra Roxa e Outras Terras, Verde, Revista de Antropofagia etc). De certo modo, essa intenção revelava o interesse dos missivistas em participar da vida cultural paulistana (e brasileira).

Com relação ao encontro com os modernistas e, em particular, com Mário de Andrade e Oswald de Andrade, Décio manifestou-se em "Oração aos velhos":

[...] em 1935, levado pelas mãos corajosas e abelhudas de Paulo Emílio Sales Gomes, entrei em contato pessoal com os modernistas da primeira geração, com destaque especial, naturalmente, para Mário de Andrade e Oswald de Andrade. Percebi, então, com espanto, que nada do que eu sabia sobre eles era verdade. Não eram irmãos e não eram loucos, embora habitassem uma Paulicéia desvairada que ficava fora dos meus limites urbanos, centrados na praça do Patriarca e no bairro de Higienópolis. E Oswald, por falar nisso, não tinha nenhum filho chamado Rolando Pela Escada Abaixo ou Lança-Perfume Rodo Metálico. Os fatos estavam ainda presentes e a lenda já os envolvia. A

\footnotetext{
32 TAVARES, Zulmira Ribeiro. Café pequeno. São Paulo: Companhia das Letras, 1995, p. 44.

${ }^{33}$ Arquivo Paulo Emílio Sales Gomes/Cinemateca Brasileira, PE/CA 0458.
} 
Semana de Arte Moderna, encerrada em 1922 e tida como brincadeira de lunáticos, começava a crescer até abarcar todo o horizonte artístico nacional. $^{34}$

Mário de Andrade é um dos intelectuais da geração modernista mais citados na correspondência. Sobre o primeiro encontro com o famoso morador da Barra Funda paulistana, Paulo Emílio escreveu:

Uma vaga curiosidade pela cidade [Cataguases] era bem anterior ao interesse por Humberto Mauro, ou mesmo por cinema. Era de natureza literária e datava de uma noite de 1935 quando Décio de Almeida Prado e eu fomos à rua Lopes Chaves, conduzidos por Cyro Monteiro Brisola, para conhecer Mário de Andrade. Da longa conversa só me lembro de dois pontos: o anfitrião nos contou que tinha muitos amigos comunistas, todos trotskistas, acrescentou, e nos falou com divertida ternura do movimento literário ocorrido em Cataguases alguns anos antes. Encantara-o um bilhete malcriado de Rosário Fusco solicitando ‘uma bosta qualquer' para a revista que estavam publicando $[$ Verde $] .{ }^{35}$

No que diz respeito ao outro Andrade, o autor das Memórias sentimentais de João Miramar, a carta de Paulo Emílio a Décio, em 21 de agosto de 1935, historia:

O Oswald de Andrade tornou-se um bom amigo meu. É uma ótima criatura muito inteligente e bem engraçado. Não sei dizer ainda se ele é culto ou não. Parece bem menos do que dizem. Segundo me disseram uns entendidos Oswald de Andrade é que é o verdadeiro renovador da literatura brasileira. ${ }^{36}$

Em 1964, Paulo Emílio, em artigo no "Suplemento Literário", afirma ter sido discípulo de Oswald de Andrade em 1935. Nesse texto, narra a altercação com o mestre, no ano do lançamento de Movimento, a propósito da crítica "O moleque Ricardo e a

\footnotetext{
34 "Oração aos velhos". Seres, coisas, lugares (Do teatro ao futebol). Ed. cit., p. 183.

${ }^{35}$ GOMES, Paulo Emílio Sales. "Motivação". Humberto Mauro, Cataguases, Cinearte. São Paulo: Perspectiva, 1974, p. 1.

${ }^{36}$ Arquivo Paulo Emílio Sales Gomes/Cinemateca Brasileira, PE/CA 0461.
} 
Aliança Nacional Libertadora", que divulgou em A Platéia criticando duramente $O$ homem e o cavalo, de Oswald. Paulo, nesse artigo, além de apontar o descompasso do autor entre o avanço de sua escrita e a classe social que pretendia alcançar, classifica como inútil as obscenidades contidas no livro e ainda cita o "desequilíbrio estilístico" da obra e sua "oratória romântica". Em última análise, o ataque a Oswald e ao seu livro era político, muito mais que literário, como explica Décio: "Que escritor era esse que, dizendo-se marxista, não abandonava os achados cômicos e o tom paródico de épocas menos empenhadas politicamente, como se a revolução fosse ocorrer entre gargalhadas?". 37

A réplica de Oswald, de 22 de setembro de 1935, também n'A Platéia foi dura: "Caro, você precisa ler $O$ Homem e o cavalo e $O$ moleque Ricardo, em vez de dizer besteira. E o que é pior - besteira reacionária. Você está simplesmente fazendo o jogo de certo tipo de desagregador que eu chamo de piolho da Revolução" ${ }^{38}$ A desavença entre eles acabou por aproximá-los, pois logo Oswald convidaria Paulo Emílio para ser secretário-geral do clube artístico que estava fundando, o "Quarteirão". Sobre essa agremiação, Décio de Almeida Prado trouxe à memória:

Quando se tentou organizar um clube, o "Quarteirão", reunindo remanescentes da Semana de 22 e outros modernistas de safra mais recente, Paulo Emílio, secretário-geral do clube - o presidente era Sérgio Milliet -, ordenou-me: "Vou te eleger para a Comissão de Literatura, mas não me apareça por lá, que essa sua timidez e essa sua cara de criança desencorajam qualquer um”. Obedeci e fui eleito. Se não cheguei a me reunir com os meus ilustres colegas de literatura foi apenas porque o clube morreu antes, de exaustão, no dia mesmo em que seus estatutos, após numerosas sessões de discussão árdua e enfadonha, acabaram por ser aprovados. Estávamos todos estafados. ${ }^{39}$

Nos carteadores, o desejo de obter reconhecimento no campo cultural era também “desejo de escrever". Tanto em trechos das cartas, quanto nas páginas de Movimento, apreende-se o vínculo fortíssimo de Paulo Emílio e Décio com o mundo das letras. Paulo Emílio que, no final da vida, adentrou o terreno da ficção com as

\footnotetext{
37 “Paulo Emílio quando jovem". Seres, coisas, lugares (Do teatro ao futebol). Ed. cit., p. 163.

38 "Bilhetinho a Paulo Emílio". Paulo Emílio: um intelectual na linha de frente. Ed. cit., p. 37-8.

39 "Paulo Emílio na prisão". Seres, coisas, lugares (Do teatro ao futebol). Ed. cit., p. 148.
} 
novelas Três mulheres de três Pppês, confidenciou no artigo "Variações municipais", no "Suplemento Literário", em 1958:

O desejo de escrever é basicamente a procura de compensação para atos frustrados. Muitas vezes vi essa ideia enunciada, mas só agora reconheço sua plena justificação. $\mathrm{O}$ que anuncia o desencadear do mecanismo compensatório é o deslize sutil que se processa da ação para a compreensão. Quando as energias se concentram no primeiro termo, o ato de escrever é apenas complementar. Do momento, porém, em que sentimos antes de mais nada a imperiosa necessidade de compreender e comunicar pela escrita os resultados do esforço de apreensão da realidade, podemos ter certeza que o ato de escrever se transformou em algo de autônomo, num substitutivo precário para o que realmente era importante para nós. Procuramos abordar problemas com certa altura de vistas para adoçar o travo da derrota. ${ }^{40}$

Gilda de Mello e Souza tratou da peculiaridade da produção de Paulo Emílio em seu estudo "Paulo Emílio: a crítica como perícia":

O método caprichoso que descobriu por conta própria, impelido pela natureza peculiar do material que examinava e por irresistível vocação interior, se alia a uma escrita extraordinariamente pessoal, inconfundível. Ela foge de todos os modelos convencionais de linguagens [...]. Desde a extrema mocidade aprendera a acolher com igual fervor as paixões mais diversas, a política, os filmes, a pintura, as amizades, e o ensinamento de tudo isso fez com que muito cedo desconfiasse do valor exclusivo dos livros e da oscilação das vogas intelectuais. Foi assim que conquistou o estilo independente de vida que se reflete com fidelidade em sua escrita: uma escrita sem tempo, sem moda, que, como ele, soube preservar na disciplina da vida universitária, o mesmo frescor da juventude - a confiança na aposta, o gosto arriscado do imprevisto. ${ }^{41}$

\footnotetext{
40 "Variações municipais". Crítica de cinema no Suplemento Literário, v. 1. Ed. cit., p. 453.

${ }^{41}$ SOUZA, Gilda de Melo e. "Paulo Emílio: a crítica como perícia". Exercícios de leitura. São Paulo: Duas Cidades, 1980, p. 220.
} 
Sobre suas iniciações no campo literário e o gosto pelas artes, Décio de Almeida Prado, em entrevista a Ana Bernstein, recorda-se:

[...] o meu gosto primeiro era a literatura. E também teatro, porque meu pai gostava muito. Ele era médico, mas tinha gostado muito de teatro e conversava sobre isso. A primeira peça que me lembro de ter visto eu tinha dez, 11 anos de idade; foi aqui em São Paulo. Depois me lembro de ter visto, junto com meu pai, as companhias portuguesas que vieram para cá. Eu tinha 12,13 anos. Assisti peças de Joracy Camargo, Deus lhe pague - naquela época eu tinha 15 anos. Aí, no ginásio, eu fui colega de ano do Paulo Emílio Sales Gomes e nós ficamos muito ligados. Ligados a cinema e ligados a teatro também. E o Paulo Emílio lançou uma revista chamada Movimento, foi a primeira revista na qual escrevi. Durou só um número e assim mesmo foi uma coisa extraordinária. O Paulo Emílio tinha 18 anos, e eu, 17. Ele era audacioso e tinha também algum dinheiro. Movimento era para ser uma revista de destaque no Brasil todo. Tinha colaboração da Lúcia Miguel Pereira e de outras pessoas do Rio de Janeiro. Mas foi uma coisa pouco duradoura. Escrevi críticas pequenas de livros, resenhas de livros. O meu primeiro amor, vamos dizer assim, é a literatura, porque meu pai gostava muito de poesia, lia poesia para mim e para os meus irmãos. Depois, o cinema. Fui fã de cinema [...]. ${ }^{42}$

Se de um lado, Paulo Emílio e Décio mostram-se interessados em dialogar com os modernistas, integrando-se no campo literário, por outro, nas cartas trocadas entre eles, também ganham destaque os nomes de Machado de Assis, Lima Barreto e Eça de Queiroz. Os carteadores trocavam, muito interessados, volumes que continham críticas sobre os livros desses autores. Só nesse conjunto de cartas, localizam-se três referências à obra de Machado de Assis. A primeira, de 12 de agosto de 1935, Décio confessa: "Recebi a Súmula e o livro sobre Machado que é interessantíssimo e muito agudo. É o trabalho sobre Machado que mais me agradou até hoje. Farei uma crítica para o Movimento expondo as minhas ideias a respeito, que elas existem". ${ }^{43}$ As duas outras referências estão em carta de 21 de agosto, em que Paulo Emílio responde ao amigo:

\footnotetext{
${ }^{42}$ A crítica cúmplice - Décio de Almeida Prado e a formação do teatro brasileiro moderno. Ed. cit., p. 294.

${ }^{43}$ Arquivo Paulo Emílio Sales Gomes/Cinemateca Brasileira, PE/CP 0027.
} 
Fiquei com a impressão de que a série de críticas que você tem sobre o Machado é uma droga, dado o seu entusiasmo pelo livro de Augusto Meyer, livro, que se bem que muito interessante, não esperava que fosse a melhor crítica sobre Machado que você já tivesse lido. Aliás um dos mais famosos trabalhos sobre Machado de Assis que é o do Pujol, eu o conheço e não tenho por ele nenhum encantamento. [...] encontrei uma coletânea de conferências, feitas na Sorbonne, sobre Machado de Assis. O volume que comentei tem um prefácio do Anatole France. Você conhece isso? ${ }^{44}$

Como se sabe, o interesse de Paulo Emílio por Machado permaneceu por toda a vida; escreveu, por exemplo, em 1958, o artigo "O narrador e a câmara - Cinema em Machado", no "Suplemento Literário" e em 1967, em parceria com Lygia Fagundes Telles, o roteiro Capitu, uma adaptação cinematográfica do romance Dom Casmurro.

Paulo Emílio utilizou a obra de Machado de Assis mais de uma vez para elaborar e pensar conceitos na crítica cinematográfica. Como professor de pósgraduação de Teoria Literária da Faculdade de Filosofia, Ciências e Letras da Universidade de São Paulo, ofereceu dois cursos: o primeiro "Dom Casmurro e cinema", em 1974, e o segundo "Machado de Assis no cinema", em 1975. Sobre os cursos escreveu Augusto Massi no apêndice da reedição de Capitu:

Ambos os cursos parecem beber na fonte de um antigo ensaio "A personagem cinematográfica", escrito para o volume coletivo $A$ personagem de ficção, que, por sua vez, foi resultado do Seminário Interdisciplinar "Teoria e análise do romance", coordenado por Antonio Candido, em 1961, ao lado de Anatol Rosenfeld e Décio de Almeida Prado, na Faculdade de Filosofia, Ciências e Letras da Universidade de São Paulo. Agora na condição de professor, é perceptível como Paulo Emílio retoma em chave madura as relações entre personagem literária e cinematográfica. Talvez por isso nas suas anotações para os dois cursos, sublinhe e aponte em cada página do

\footnotetext{
${ }^{44}$ Arquivo Paulo Emílio Sales Gomes/Cinemateca Brasileira, PE/CA 0461.
} 
romance, o breve perfil físico e psicológico das personagens: Capitu, Bentinho, Escobar etc. ${ }^{45}$

Na vida de Décio de Almeida Prado, o interesse pelas artes surgiu graças ao pai, Antonio de Almeida Prado, médico respeitado que gostava de literatura e de teatro, incutindo esse gosto no filho: liam juntos a poesia de Bilac e Martins Fontes, este último, amigo da família.

Ainda que a atuação de Décio como crítico teatral tenha se dado apenas em 1941, com o surgimento da revista Clima, as cartas trocadas com Paulo Emílio, em 1935, já revelam o gosto especial pelo teatro. Em 1 de agosto, deixa entrever a sua veia crítica:

[...] V. elogia, sem restrições nesse sentido, o teatro de Renato Viana, que é teatro de tese, freudiano, antipopular, feito para as elites que aguentam uma peça monótona, dialogada, porque acham interessante a tese. [...]. Pelo que li, Sexo pode ser um bom espetáculo, interessante e inteligente, mas não é teatro onde o principal é ação. Se houver tese, a ação é que deve demonstrá-la sem auxílio dum sujeito (nesse caso Dr. Calazans) muito inteligente, que explica tudo ao público. Qual Paulo, isso de teatro é cá conosco... V. confunde literatura e teatro ${ }^{46}$.

\section{“A revista [...] vai otimamente. Já está nas provas" $" 47$}

Movimento - revista do presente que enxerga o futuro, lançada em julho de 1935, caracterizou-se como uma tentativa de incursão no ambiente literário, artístico e político de São Paulo. Paulo Emílio Sales Gomes e Décio de Almeida Prado, os "diretores" e o "gerente" Paulo Afonso de Mesquita Sampaio, primo de Décio e companheiro do "Cassino", pretendiam, com a publicação, promover ampla e duradoura discussão estética e ideológica. Em "Paulo Emílio quando jovem”, Décio afirma:

É provável que no seu [de Paulo Emílio] espírito os dois movimentos, o artístico e o político, corressem paralelos. Ambos ainda próximos de

\footnotetext{
${ }^{45}$ GOMES, Paulo Emílio Sales \& TELLES, Lygia Fagundes. Capitu. São Paulo: Cosac Naify, 2008, p. 186-7.

${ }^{46}$ Arquivo Paulo Emílio Sales Gomes/Cinemateca Brasileira, PE/CP 0041.

${ }^{47}$ Arquivo Paulo Emílio Sales Gomes/Cinemateca Brasileira, PE/CA 0454.
} 
seu momento de explosão, ambos colados ao presente, refletiam a face apenas pressentida do futuro. Os dois significavam um começo, não um apogeu, muito menos um fim de jornada. ${ }^{48}$

É com esse caráter dúbio, entre a seriedade, o racionalismo, a disciplina presentes no pensamento marxista e a liberdade artística, a ironia, o lúdico, bases das inovações estéticas modernistas, que podemos entender Movimento e as produções de Paulo Emílio no período, entre as quais se inclui o "Manifesto" da revista. Neste, a tentativa - ainda que intuitiva - de harmonia entre esses "dois movimentos, o artístico e o político" são evidentes.

Uma das características mais curiosas de Movimento, presente também nas cartas, é a criação, por parte de Paulo Emílio, de diversos pseudônimos que integram um vasto quadro de colaboradores novíssimos, como pretendia o fundador. Cabe ressaltar que um desses pseudônimos, Joaquim Mauriti, ou o Quinquim, assina carta dirigida a Décio de Almeida Prado, em 17 de agosto. Sobre os pseudônimos de Paulo Emílio, Décio teceu considerações:

O ano anterior à carta, 1935, havia sido o do nosso acesso à literatura. Terminado o ginásio, que cursamos juntos, já tendo ido por água abaixo o plano de nos tornarmos médicos como nossos pais, só nos restava fazer a nossa entrada triunfal na vida artística paulista. Conhecemos a dupla sagrada, Mário e Oswald de Andrade, fora outras divindades menores, e publicamos Movimento, revista do presente que enxerga o futuro. Embora a revista se referisse entusiasticamente aos 'novíssimos', não me recordo que houvesse mais do que dois. Um deles, o Paulo naturalmente, compensava essa deficiência multiplicando-se em meia dúzia de heterônimos, nascidos não de uma irresistível vocação à la Fernando Pessoa, mas da necessidade imediata de preencher as páginas do Movimento com alguns nomes inéditos, sugerindo toda uma geração ansiosa por subir. Nasceram assim, entre outros, o poeta operário Hag Reindrahr, que dedicava um poema aos seus colegas de mictório da fábrica, Ray Barbosa, neto

\footnotetext{
48 “Paulo Emílio quando jovem". Seres, coisas, lugares (Do teatro ao futebol). Ed. cit., p. 161.
} 
natural de Ruy Barbosa, e o crítico teatral Joaquim Mauriti, conhecido pelos amigos como Quinquim. ${ }^{49}$

Philippe Lejeune analisa o uso de pseudônimos em $O$ pacto autobiográfico, contribuindo para que se possa compreender a estratégia de Paulo Emílio nas páginas de Movimento:

Um pseudônimo é um nome diferente daquele que foi registrado em cartório, usado por uma pessoal real para publicar todos os seus escritos ou parte deles. O pseudônimo é um nome de autor. Não é exatamente um nome falso, mas um nome de pena, um segundo nome, exatamente como aquele que uma freira adota ao ser ordenada. É certo que o emprego do pseudônimo pode, às vezes, encobrir um embuste ou ser imposto pela discrição [...]..$^{50}$

Assim, Paulo, através de seus pseudônimos criava a impressão de que o periódico agregava muitos colaboradores "novíssimos", fato que comprovava sua tese de que sua geração tinha muito o quê dizer e seus componentes estavam presentes para fazê-lo. ${ }^{51}$

Os diretores tencionavam publicar muitos números da revista, contando com novos colaboradores e simpatizantes. As informações contidas na folha de rosto, sumário e contracapa indicam essa pretensão, mas não foi o que aconteceu; a revista teve um único número, que tratava de diversos assuntos, como explica Paulo Emílio: "Nunca fui fã , pelo menos de cinema, última das expressões intelectuais e artísticas a conquistar a minha atenção. Uma revista que fundei em 1935 cuidava de tudo exceto de filmes". 52

Com 122 páginas, impressão tosca e diversos erros de revisão e diagramação, Movimento traz na capa ilustração de Anita Malfatti, desenho simples, com formas

\footnotetext{
49 "Paulo Emílio na prisão". Seres, coisas, lugares (Do teatro ao futebol). Ed. cit., p. 147.

${ }^{50}$ LEJEUNE, Philippe. "Eu abaixo-assinado". O pacto autobiográfico: de Rousseau à internet. Organização de Jovita Maria Gerheim Noronha. Tradução de Jovita Maria Gerheim Noronha e Maria Inês Coimbra Guedes. Belo Horizonte: Editora UFMG, 2008, p. 24.

${ }^{51}$ Da mesma estratégia lançou mão o jovem Monteiro Lobato, em relação ao Minarete, "jornalzinho que Benjamin Pinheiro manteve em Pindamonhangaba de julho de 1903 a julho de 1907". Em nota à carta de 9 de dezembro de 1903, de A barca de Gleyre, Lobato explicita: "Eu me divertia fazendo de longe [São Paulo] o Minarete quase inteiro. Quantos números totalmente escritos por mim [...]. Isso me forçava a um grande sortimento de pseudônimos, para dar ao público a impressão de que o jornal dispunha de um exército de colaboradores [...]". (LOBATO, Monteiro. A barca de Gleyre. São Paulo: Globo, 2010, p. 389).

52 "Impressões cariocas”. Crítica de cinema no Suplemento Literário, v. 2. Ed. cit., p. 107.
} 
geométricas acompanhando o título que corre na diagonal, criando um efeito de "movimento". ${ }^{53}$ Em tom irônico, Décio escreveu a Paulo, em 1 de agosto de 1935: "Não desista V. do desenho que os seus já estão quase iguais ao da Anita". ${ }^{54}$ Paulo admitiu que os desenhos foram feitos com muita "frieza". Estampados na capa também se lê “julho, agosto, setembro", "São Paulo" e o ano "1935".

O sumário, na primeira página, põe a vista os problemas de revisão do periódico, pois há diferenças entre os títulos dos textos ali apresentados e os que aparecem no miolo. O artigo de Paulo Emílio "Considerações sobre o artista revolucionário na sociedade burguesa", por exemplo, aparece aqui como: "A posição do artista revolucionário na sociedade burguesa”. E ainda, segundo o sumário, deveria ser o terceiro artigo da revista, no entanto é o oitavo.

A indicação dos colaboradores do segundo número, na página dois, explicita a intenção pretendida pela revista: juntar diferentes gerações intelectuais. Ganhariam as páginas de Movimento a contribuição de Décio de Almeida Prado, (“Agripino Grieco”); de Ver a Vicente de Azevedo ("Ensaio sobre cultura”); de Paulo Emílio ("Lenin (síntese biográfica e psicológica)" e "Belmonte"); de Anita Malfatti ("O ensino da pintura no Brasil"); de Miguel Ferreira da Silva Netto ("Livre câmbio e protecionismo"); de V. Nezval ("Super realismo tcheco-slovaco"); de Hag Reindrahr - grafado nessa página "Harnhestein" - (poema "Porão"); entrevistas com Gaston Denys Perier e Ben Nicholson. Acrescentava-se, por fim, a informação genérica: "Mauricio de Medeiros, Gilberto Amado, Miguel Osório de Almeida, Porto Carrero, Leônidas de Rezende, Castro Rebello - também escreverão para o segundo número de MOVIMENTO.” Nessa mesma página se lêem as orientações para obtenção de assinatura mensal ou anual, esta por "15\$000", bem como dos dizeres: "Movimento pede que lhe enviem todas e quaisquer notícias sobre ele publicadas"; “Movimento pede impressões. Escreva-nos"; "Queremos manter intercâmbio com outras publicações", sinalizando que os diretores esperavam que o número tivesse alguma repercussão.

O "Manifesto", apresentando na terceira e quarta páginas de Movimento não exibe assinatura, mas sabemos, graças à correspondência entre os "diretores", ser de autoria de Paulo Emílio. É um texto curto, apresentando as intenções políticas e estéticas que almejavam a revista. No texto, destaca-se o percurso de sua elaboração: "Depois de cinco meses de planos, esboços, trabalhos, viagens, conversas, cansaço,

\footnotetext{
${ }^{53}$ Capa reproduzida no Anexo.

${ }^{54}$ Arquivo Paulo Emílio Sales Gomes/Cinemateca Brasileira, PE/CP 0041.
} 
risadas, imprecações, desânimos, alegrias, apresentamos à mocidade brasileira 0 primeiro número de sua revista. Sua revista sim!”; suas intenções: "A geração que nos antecedeu recua, apodrecendo. Nós precisamos avançar e ocupar os postos para os quais estamos sendo chamados por uma necessidade social de novas energias, novas concepções, novo sangue, nova moral..."; "MOVIMENTO é o entrechoque de filosofias, é a batalha de concepções"; e suas conquistas: "Neste nosso empreendimento temos o apoio intelectual e material de elementos de outra geração, que se puseram ao nosso lado". 55

Décio de Almeida Prado não gostou do "Manifesto" e escreveu outro, enviado a Paulo Emílio em carta de 1 de agosto de 1935, para ser eventualmente publicado no lugar do primeiro, “mas já como artigo e assinado". Segundo ele:

a minha apresentação seria, penso, mais prudente, menos arrebatada, melhor para os espíritos burgueses que a sua, não deixando de ter ao mesmo tempo um tom avançado. A sua tem a vantagem, importante no Movimento, de ser mais agitada, menos prudente (não sei se você me compreende) parecendo, mais que o meu, artigo de moço. Porque talvez eu não seja mais velho que $\mathrm{V}$. mas sou seguramente mais antigo. $^{56}$

Paulo Emílio não concordou com a sugestão do amigo e respondeu: "Qto à sua apresentação achei-a gelada demais para apresentar a revista. Já no segundo número irá mto bem". 57 E ainda comenta o "lamentável antiguismo" do amigo, dizendo que esse será assunto para uma carta inteira.

A primeira seção de Movimento, intitulada Filosofia tem 17 páginas, trazendo um único e longo artigo "Filosofia clássica e filosofia científica", com a assinatura de Pontes de Miranda. $\mathrm{O}$ artigo traz uma extensa reflexão sobre a evolução do pensamento filosófico, desde o pensamento clássico até o moderno (científico). Carregado de termos e de expressões filosóficas, como "o ignoramus e o ignorabimus", "homem menor do que o saber", "as afirmações idealistas, e as afirmações realistas, as convicções sobre essências ônticas, e sobre fatalidade relativista do pensamento", o ensaio causou nos carteadores um misto de encantamento e rejeição. Décio ajuizou: "Não consegui

\footnotetext{
${ }^{55} \mathrm{O}$ "Manifesto", o sumário e a página 2 estão reproduzidos no Anexo.

${ }^{56}$ Arquivo Paulo Emílio Sales Gomes/Cinemateca Brasileira, PE/CP 0041.

${ }^{57}$ Arquivo Paulo Emílio Sales Gomes/Cinemateca Brasileira, PE/CA 0460.
} 
entender o artigo do P. de Miranda na primeira e única tentativa que fiz nesse sentido. $\mathrm{O}$ pouco que entendi, gostei. Pouca gente o lerá". ${ }^{58}$ Paulo, concordou: "O artigo de Pontes de Miranda está mesmo confusíssimo. Está mesmo mto mais confuso que os seus livros (conheço dois) que já têm essa fama. Não obstante está interessantíssimo e, não sei se você sabe, é quase completamente original". 59

A segunda seção, Sociologia, com 22 páginas, congrega três artigos. O primeiro, "Interpretação materialista da revolução de São Paulo" não revela autoria; traz a nota de rodapé: "Este curioso ensaio foi traduzido do espanhol. O original não traz discriminação do nome do autor". O artigo, extraído de panfleto da III Internacional, como afirma Paulo em carta a Décio, trata das revoluções de 1930 e 1932, principalmente na cidade de São Paulo. Sabe-se também, por meio das cartas, que a tradução foi feita por Paulo Emílio e que o autor é "Labirse", 60

O segundo ensaio da seção, "A grande sacrificada", é subscrito pela crítica literária mineira Lúcia Miguel Pereira e trata dos problemas de influências que uma geração exerce sobre outra. Ela avalia: "Os pais e os mestres precisam se conformar com essa iniciação às vezes dolorosa, mas sempre imprescindível. Uma geração não pode absorver a outra, nem mesmo para lhe poupar sofrimentos". Apresenta também o papel da mulher na sociedade: “Aos vinte anos, o homem (o homem e a mulher, agora que também ela vai começando a querer pensar) é assim uma força em estado potencial $[\ldots] "$

O terceiro ensaio é, na verdade, uma notícia assinada pelas iniciais H. H., com o título "A semana da educação sexual em S. Paulo"; é uma forte crítica aos estudantes da Faculdade de Direito que haviam frequentado às palestras do Dr. José de Albuquerque para a semana de Educação Sexual na cidade, ocorrida no Clube Comercial em julho de 1935. H.H escreve:

No último dia da semana de Educação Sexual, terminada a sua conferência, o Dr. José de Albuquerque resolveu ceder a palavra a quem a solicitasse. Uma criatura de óculos resolveu fazer umas considerações sobre a prostituição relacionada com o regime capitalista. Tendo certa dificuldade em falar, não conseguiu finalizar as suas considerações porque um magote de bobos começou a dar

\footnotetext{
${ }^{58}$ Arquivo Paulo Emílio Sales Gomes/Cinemateca Brasileira, PE/CP 0041.

${ }^{59}$ Arquivo Paulo Emílio Sales Gomes/Cinemateca Brasileira, PE/CA 0460.

${ }^{60}$ Arquivo Paulo Emílio Sales Gomes/Cinemateca Brasileira, PE/CA 0460.
} 
risadas, guinchos, gritinhos com voz fina, apartes de Faculdade de Direito e assobios [...] Aqui fica a nossa opinião: a atitude desses rapazes foi sem oportunidade, ginasiana, mesquinha e covarde.

Provavelmente H.H. é um dos pseudônimos de Paulo Emílio na revista, na medida em que representa a "nossa opinião".

A seção Sociologia encerra-se com a notícia "Vida do operário em S. Paulo", assinada por C.P. (mais um pseudônimo?) que anuncia o estudo de Paulo Emílio e Fernando Alayon sobre o nível de vida do operário em São Paulo e que deveria sair no segundo número de Movimento.

A terceira seção, Literatura, com 19 páginas, abre-se com "Roberto" de Mário de Andrade, resenha sobre o livro Roberto de Sérgio Milliet. ${ }^{61}$ Mário busca uma definição crítica do romance do amigo modernista:

Roberto é o problema do despaisado. É um ser que não se acomoda em pátria nenhuma, nem do espírito nem da terra, na Suíça desnorteado pelo seu brasileirismo sentimental e depois no Brasil, como um meteca oriundo de civilizações mais organizadas, vendo tudo de cima, com uma sobranceria desumana, um apriorismo incapaz de amar, e consequentemente de compreender.

Décio avaliou positivamente a resenha, escrevendo a Paulo Emílio em 1 de agosto de 1935: “O artigo do Mário de Andrade muito bom. Eu não tinha visto no livro nada do que ele enxergou. Estou quase relendo - o que aumentou o meu interesse por ele". ${ }^{62}$

Na sequência, lê-se "O Rabo e o homem (Short Fisiológico)", excerto da novela Diabo de Luiz Navarro Filho, texto cômico, no qual o autor apresenta quais seriam as vantagens do ser humano em possuir um rabo: "nunca foi pelo mundo encarada a possibilidade de fazer ele parte do organismo, nem nunca foram avaliadas as formidáveis vantagens de tal". Ressalta as "vantagens estéticas": "o maior predicado de estesia de nosso organismo", informação seguida de um desenho de um homem forte, musculoso, dono de um rabo longo, até o chão; "vantagens físicas": "Com quatro membros, o homem já era capaz de prodígios de destreza. Do que é capaz, possuindo um rabo..."; "vantagens morais": "No campo ético, o rabo é soberbo.”; “vantagens

\footnotetext{
${ }^{61}$ Resenha reproduzida no Anexo.

${ }^{62}$ Arquivo Paulo Emílio Sales Gomes/Cinemateca Brasileira, PE/CP 0041.
} 
espirituais": "No programa do espírito desempenha o rabo papel de alto valor, desenvolvendo no homem possibilidades mais amplas de melhor sucesso"; "vantagens sentimentais": "Eis que finalmente cabe-nos referir a grandiosidade de nossa vida amorosa, sob a tutela opulenta do rabo". Paulo Emílio, em carta de 8 de agosto, julga que o amigo não compreendera o objetivo do artigo: "você critica com uma seriedade científica um artigo que evidentemente foi feito para provocar gargalhadas". 63

A seção Literatura fecha-se com os versos de Cyro Brizola, Fernando Mendes de Almeida e de Hag Reindrahr. Este último assina "Trecho de vida", ${ }^{64}$ poema dedicado aos "companheiros de prosa do mictório da fábrica", delineando a figura de um operário tuberculoso. Sobre a criação, por parte de Paulo Emílio, da figura de Hag Reindrahr e seu poema, há algumas considerações importantes, na medida em que sua criação vai além do intuito em multiplicar os colaboradores. Hag encarna a crítica aos ideais do comunismo ortodoxo e ele próprio cumpre o questionamento de classe a que se submete Paulo Emílio, na condição de herdeiro de uma família burguesa, proprietária de uma indústria de tecido. O poema vem para "caçoar levemente de coisas sagradas", como explica Décio:

A figura de Hag Reindrahr parece nascer de dois impulsos, o primeiro de exaltação revolucionária autêntica e o segundo de um fundo de ironia, de distanciamento crítico, talvez de ceticismo, que não resiste à tentação de caçoar levemente das coisas sagradas, sem o mais remoto desejo de suprimi-las. ${ }^{65}$

Arte é o título da quarta seção, que tem 17 páginas, reunindo quatro ensaios. $\mathrm{O}$ primeiro, "Considerações sobre o artista revolucionário na sociedade burguesa (A propósito da morte de Facio Hebequer)", de Paulo Emílio, é, como “Trecho de vida", questionamento de conceitos rígidos usados pela esquerda brasileira. Paulo Emílio avalia as posições do artista, do intelectual, da burguesia na sociedade e apresenta sua posição em face das relações entre arte e revolução. Ele conclui:

$\mathrm{Na}$ sociedade atual, o sapateiro existe para fazer sapatos para o burguês, e o pintor para fazer quadros, também para o burguês. Por

\footnotetext{
${ }^{63}$ Arquivo Paulo Emílio Sales Gomes/Cinemateca Brasileira, PE/CA 0460.

${ }^{64}$ Poema reproduzido no Anexo.

65 “Paulo Emílio quando jovem”. Seres, coisas, lugares (Do teatro ao futebol). Ed. cit., p. 164-5.
} 
essa atitude ninguém deve merecer o boicotamento de seus companheiros. Mesmo porque, ainda que o indivíduo seja militante, unicamente como artista, não deve ser censurado. Em nossa Revolução existem muitos setores de combate. E um dos importantes é o artístico. A arte política tem grande valor como incentivo à revolta.

Em sua tese de que o artista revolucionário deve produzir para a burguesia, mas sem se afastar da "massa", finaliza o texto questionando o leitor e ao mesmo tempo esclarecendo-o: "Será dubiedade o contato com a burguesia e a produção artística revolucionária? É dubiedade o fazer-se sapatos para o burguês e o conspirar-se no sindicato?". Paulo Emílio termina o artigo explicando sua origem:

Eu pensei nessas coisas todas que escrevi, ao saber da morte, na Argentina, do grande pintor socialista Guilherme Facio Hebequer. Aparentemente isso é esquisito, pois Facio Hebequer foi um artista exclusivamente de massas, detestando a classe burguesa. Não há absurdo algum. O que aconteceu foi simplesmente isso - tendo na frente uma exceção, me lembrei da regra geral.

O segundo artigo da seção Arte é de Flávio de Carvalho, intitulado "As novas tendências da pintura contemporânea". Trata-se de extensa reflexão do autor sobre a pintura contemporânea no Brasil e na Europa, reflexão possível graças aos anos em que estudou no exterior.

Nas páginas seguintes, a revista apresenta Teatro, subseção de Arte; estampa o comunicado da redação:

O principal encarregado desta seção de Movimento, será Renato Viana, o grande animador do teatro brasileiro. Infelizmente, para o primeiro número, foi absolutamente impossível a Renato Viana enviar a sua colaboração, dada as suas enormes preocupações com o TeatroEscola e a exiguidade do tempo. Do segundo número em diante, entretanto, é garantido. Devido a isso é que a nossa seção de teatro sai no primeiro número tão incompleta. 
Com a ausência de Renato Viana, Paulo Emílio encarregou-se, por meio de dois pseudônimos, dos dois textos da seção: "Teatro-Escola de São Paulo", de Ray Barbosa, e "Sexo de Renato Viana", de Joaquim Mauriti, o Quinquim. O primeiro é uma pequena nota sobre a fundação de um Teatro-Escola em São Paulo, sob a direção de Alves Filho, "o jovem e imaginativo autor de planos para clubes, teatros, revistas", nos moldes do Teatro-Escola de Renato Viana. O segundo texto é uma resenha apreciativa da peça Sexo de Renato Viana, responsável pela estreia do Teatro-Escola em São Paulo.

Em seguida, "Sala de Arte de S. Paulo - uma pequena exposição coletiva" assinado por G.F. informa sobre a exposição na sala de chá da Casa Alemã, a qual contava com "numerosas demonstrações de John Graz", artista referido por Paulo na carta a Décio, em 21 de agosto de 1935. A seção Arte encerra-se com "Arte Soviética" de Pera Neto (certamente um pseudônimo), relato dividido em quatro partes: "Ópera e teatro", "Exposição de cerâmica", "Exposição de pintura e escultura" e "Exposição infantil de arte".

A quinta seção, Entrevistas, preenche nove páginas e apresenta palavras da declamadora Berta Singerman, de Otokar Fisker, reitor da Universidade Carlos IV de Praga e de Margaret Ludwig, sobre a música moderna inglesa. As duas primeiras, não divulgam o autor da entrevista. Segundo informa José Inácio de Melo Souza: “a primeira com a declamadora Berta Singerman, realizada por Cyro Brisola e copidescada por Paulo, outra com Otokar Fisker, reitor da Universidade Carlos IV de Praga (mandada por Flávio de Carvalho, segundo informação de Rui Moreira Leite)" "66; a terceira que traz as iniciais "F. de C.", provavelmente, é também de Flávio de Carvalho.

Na seção Livros novos, com 19 páginas, divulgam-se 15 resenhas; oito assinadas por Paulo Emílio. São elas: Supay (diálogos) de Guillermo Francovich; Marcha sobre Roma... e arredores de Emilio Lussu; Segredos de Aluizio Napoleão; Tosquia de um escritor de Francisco Mangabeira Albernaz; A ditadura fascista na Alemanha de O. Piatnitsky; Princípios de economia política de Lapidus e Ostrovitianov; Ideias, homens e fatos de Mauricio de Medeiros e "Livros de Mário de Andrade" sobre a edição, em um único volume, dos ensaios $O$ Aleijadinho e Álvares de Azevedo. Uma das resenhas "Segunda edição de um romance de V. CY.", focalizando obra de Vivaldo Coaracy, Frida Mayer, tem como autor as siglas "E. P.”; trata-se, possivelmente, de um erro de diagramação, causando a inversão das letras iniciais do nome de Paulo Emílio. Duas

\footnotetext{
${ }^{66}$ Paulo Emílio no Paraíso. Ed. cit., p. 58.
} 
resenhas são assinadas por "D.A.P." (Décio de Almeida Prado): Crítica de Humberto de Campos e Patrocínio de Osvaldo Orico. ${ }^{67}$ Uma por "M.F.S.N." (Miguel Ferreira da Silva Neto), A luta pelo petróleo de Essad Bey ("pseudônimo de um dos magnatas do petróleo e notável escritor moderno") e três resenhas sem assinatura abordando $A$ palavra e o pensamento Integralista de Gustavo Barroso; Zumbo Coral, Diabo e Diel, de Luiz Navarro Filho e Salgueiro de Lúcio Cardoso.

Na seção Revistas, com cinco páginas, as nove resenhas foram assinadas por Isac Blion Martins, um pseudônimo. São comentários sobre alguns periódicos importantes da época, como Revista Brasileira, Novela, Inteligência, Revista Contemporânea, Revista do Clube de Cultura Moderna, Geografia, Súmula, Seiva e Boletim de Ariel.

Movimento termina com a seção Notas sobre Arte, ocupando oito páginas, estampando reproduções de obras de arte dos artistas Renoir, Mabel Lapthorn, Ben Nicholson, Filla, Arne Hosek, Jean Helion, Tanguy e Henri Matisse, seguidas de pequenos comentários não assinados. Alguns desses artistas (como Arne Hosek e Mapel Lapthorn) são citados no artigo de Flávio de Carvalho, o que nos leva a pensar que a escolha e anotação dessas reproduções são dele.

A última página divulga fotografia da entrevistada Berta Singerman com a dedicatória: "Para a revista Movimento com toda simpatia, Berta Singerman".

$\mathrm{Na}$ contracapa da revista ${ }^{68}$ aparece o editorial, ou seja, os nomes de quem a produziu. A direção é de Paulo e Décio; a gerência de Paulo Afonso de Mesquita Sampaio. Também se apresenta nesse local o conjunto dos colaboradores do número: André Dreyfus, Pontes de Miranda, Flávio de Carvalho, Anita Malfatti, José O. Andrade, Lúcia Miguel Pereira, Leônidas Ferreira, Mauricio de Medeiros, Oswald de Andrade, Miguel Ozório de Almeida, Mário de Andrade, Vera Vicente de Azevedo, Cyro Brisola, Miguel F. da Silva, Lenício Ferreira, Luiz Navarro Filho, Túlio de Lemos, Gilberto Amado, Rodolfo M. Sampaio.

É curioso notar que o endereço da redação "Veiga Filho, 323" era o mesmo da casa de Paulo Emílio e de sua família, local em que ocorreram muitas reuniões para esse projeto e para outros, como "Cassino" e "Quarteirão", como podemos verificar na correspondência.

\footnotetext{
${ }^{67}$ Resenha reproduzida no Anexo.

${ }^{68}$ Contracapa reproduzida no Anexo.
} 
A distribuição "para todo o Brasil" ficou a cargo de "Centro de Expansão do livro e da imprensa - Rua Boa Vista, 31, $7^{\circ}$ - tel. 2-8000".

As cartas presentes nesta dissertação contam a história do lançamento da revista, com muitos detalhes. Movimento ficou conhecida na imprensa graças ao escândalo ocorrido por ocasião de seu lançamento, como Décio já havia previsto em carta de 1 de agosto: "Não creio que Movimento fará sucesso, a não ser escandaloso". O bibliotecário do Conservatório Dramático e Musical de São Paulo, Nestor de Assis Ribeiro, achou a revista "imoral e dissolvente", por trazer "palavras que ofendem o decoro" e então rasgou o periódico em público. Paulo Emílio indignou-se com o fato e aproveitou para tirar dele projeção para o periódico e para si, convidando o bibliotecário, através de carta publicada em 12 de agosto, no Diário da Noite, a provar suas afirmações ou, ao contrário, a um "duelo a tapas". O circo foi montado e a revista comentada, principalmente, por figuras do modernismo como Oswald de Andrade, que com humor agudo, escreveu a Paulo Emílio um bilhete se solidarizando com o ocorrido:

Paulo Emílio, você não tem nenhuma razão. Quem tem é o homenzinho. Ele vai fazer uma biblioteca de guarda-chuvas. Você atrapalha. Num conservatório de múmias, o menor movimento atrapalha. Quanto mais o seu que é certo. Disponha como testemunha do Oswald de Andrade. Obs. Se no duelo houver lugar para a Cruz Vermelha, indico o Sr. Plínio Salgado. ${ }^{69}$

\section{"biografia de grupo"70}

Em 21 de agosto de 1935, Paulo Emílio Sales Gomes, escrevendo a Décio de Almeida Prado, avalia que os surgimentos de Movimento e de "Quarteirão" tinham favorecido a aproximação com diversas figuras do campo artístico e intelectual de São Paulo.

A rede de sociabilidade, constituída em torno da revista e de seus diretores, está evidente no conjunto de cartas estudado. Entre os nomes que pululam nas mensagens, encontram-se o de pessoas que fizeram parte da movimentação às voltas da revista Movimento, do "Cassino", de "Quarteirão", assim como o daquelas que continuaram se

\footnotetext{
${ }^{69}$ Arquivo Paulo Emílio Sales Gomes/Cinemateca Brasileira, PE/CP 0053.

${ }^{70}$ CANDIDO, Antonio. "Poesia e ficção na autobiografia". A educação pela noite e outros ensaios. Rio de Janeiro: Ouro sobre Azul, 2006, p. 68.
} 
encontrando com Paulo e Décio em outros projetos, como a revista Clima, ou ainda em espaços de cultura paulistanos, como a Universidade de São Paulo, a livraria Jaraguá, a Cinemateca Brasileira, e a redação d'O Estado de S. Paulo.

A rede de sociabilidade pode ser recuperada a partir de nomes citados na correspondência. Além de Mário e Oswald de Andrade, surgem outros nomes ligados ao primeiro tempo modernista, como os escritores Jaime Adour da Câmara e Antonio de Alcântara Machado e os artistas plásticos Anita Malfatti, John Graz e Victor Brecheret. Recupera-se ainda a figura aristocrática de René Thiollier, um dos financiadores da Semana de 22. Para José Inácio de Melo Souza, o "escritor [...] era uma instituição da Academia Paulista de Letras (Décio tinha pesadelos com ele, em 1935, pelo que representava como modelo de intelectual acadêmico)". 71

Entre os detratores do modernismo, conta-se, nas cartas, o nome de Mário Pinto Serva, autor dos textos da Folha da Noite que atacavam a Semana de 22, e de Alfredo Mário Guastini. Este, jornalista polêmico, divulga no Diário de S. Paulo em 30 de julho de 1935, assinando-se "G.", artigo favorável a Movimento, causando satisfação em Paulo Emílio.

Monteiro Lobato, nas cartas, merece um comentário à parte, na medida em que o convite feio a ele para colaborar em Movimento (expresso nas entrevistas concedidas por Paulo Emílio aos jornais) ganha tons jocosos, uma "piada" da qual Décio afirma, em carta de 18 de julho, que gostou. O propósito de contar com a participação do autor de "Paranoia ou mistificação?" - a famosa crítica de 1917 repudiando a arte de vanguarda de Anita Malfatti, quem, agora, aliás, assinava o desenho da capa de Movimento - na revista com "ares modernistas" sinaliza o caráter irônico das declarações de Paulo aos jornais: "Acho que ele, para construir conosco não serve. Em todo caso, poderá e com muita eficiência, nos ajudar na destruição. Creio que se sentirá muito à vontade nesse campo". ${ }^{72}$; "Tenho certeza de que não nos negará seu apoio. Ele tem tanto interesse pelas crianças...". 73

À margem do movimento modernista, o nome do dramaturgo Renato Viana merece destaque. Como se viu anteriormente, apresentado em Movimento como o futuro encarregado da seção destinada ao teatro, Renato Viana, com a criação de seu TeatroEscola em 1934 no Rio de Janeiro, era figura respeitada na discussão sobre a existência

\footnotetext{
${ }^{71}$ Paulo Emílio no Paraíso. Ed. cit., p. 232.

${ }^{72}$ Entrevista de Paulo Emílio ao Correio de S. Paulo em 21 de junho de 1935.

${ }^{73}$ Entrevista de Paulo Emílio ao Diário da Noite em 29 de junho de 1935.
} 
da produção teatral nacional. Para ele, como explica Ana Bernstein, "o teatro brasileiro não existiria e nem poderia existir, visto ser a arte teatral a culminância da cultura de um povo e, sendo o Brasil uma nação ainda em fraldas, seria impossível, por conseguinte que possuísse cultura teatral". ${ }^{74}$ Renato Viana, explicando a sua tese, afirma: “[...] nossa literatura dramática nasceu de sete meses e morreu anjinho [...]. Evidentemente sob esse ponto de vista não existimos [...]. O que hoje temos é um falso teatro, um teatro de imitação e de tradução, vazio de qualquer característica nacional". ${ }^{75}$ Décio - mesmo sem o saber - já muito mais afinado com o assunto que Paulo Emílio, critica a tese de Viana e este, de fato, perde importância no cenário cultural brasileiro tempos depois.

Da geração seguinte, detecta-se nas cartas a presença expressiva de Lúcia Miguel Pereira e de Flávio de Carvalho. A primeira teve posição de vanguarda na atividade crítica "militante", a qual, segundo Antonio Candido, "exerceu com destemor, competência e penetração. [...]". ${ }^{76}$ Contudo, nas cartas, a crítica parecia ocupar um lugar ambíguo. Décio avalia, em 18 de julho: "Estranhei V. incluir, nas duas entrevistas, Lúcia Miguel Pereira entre a velha geração. Ela tem vinte e poucos anos, começou a escrever com o Boletim de Ariel há uns três anos e apesar de inteligente, sempre é mulher. Foi gafe, na minha opinião". Flávio de Carvalho, pela vez dele, nas mensagens, é citado como referência de vanguarda no que tange às artes plásticas e ao teatro: "Trata-se de novos conhecimentos que ando adquirindo, mas não é por meio de livros, mas sim por conversas que tenho mantido com o Flávio e o Oswald."77; “Ao contrário do que esperava achei entendível o artigo do Fernando [sic] de Carvalho e bastante interessante para quem, como eu, não tinha noção sobre o assunto pintura moderna. Tenho cá umas dúvidas que depois formularei e quero que Flávio de Carvalho me esclareça."78; “o pessoal (Oswald de Andrade, Flávio de Carvalho, Geraldo Ferraz, Vera Azevedo) de uma maneira geral não gostou da capa."79

Sobre sua importância, Paulo Emílio afirmou no "Suplemento Literário", em 1958: "Não sei se as gerações mais jovens têm uma ideia exata do que o movimento artístico brasileiro deve a Flávio de Carvalho. Ninguém discute ser ele o melhor retratista brasileiro ou a excelência de seu desenho, mas tende-se a esquecer a sua

\footnotetext{
${ }^{74}$ A crítica cúmplice - Décio de Almeida Prado e a formação do teatro brasileiro moderno. Ed. cit., p. 34.

${ }^{75}$ A crítica cúmplice - Décio de Almeida Prado e a formação do teatro brasileiro moderno. Ed. cit., p. 35.

${ }^{76}$ CANDIDO, Antonio. "Lúcia". O albatroz e o chinês. Rio de Janeiro: Ouro sobre Azul, 2004, p. 127.

${ }^{77}$ Arquivo Paulo Emílio Sales Gomes/Cinemateca Brasileira, PE/CA 0458.

${ }^{78}$ Arquivo Paulo Emílio Sales Gomes/Cinemateca Brasileira, PE/CP 0041.

${ }^{79}$ Arquivo Paulo Emílio Sales Gomes/Cinemateca Brasileira, PE/CA 0460.
} 
influência, negativa ou positiva, em outros terrenos. Se por um lado é certamente um dos responsáveis pela moderna arquitetura brasileira, por outro foi o criador do Teatro de Experiência. Quando o teatro brasileiro entrar em um estágio de desenvolvimento superior, mais diversificado, serão relembradas as aventuras de 1933 do autor do Bailado do Deus Morto". 80

Há nessas cartas uma extensa relação de nomes de personalidades de maior ou menor relevo no campo cultural brasileiro: Alfredo Pujol (estudioso de Machado de Assis); Agripino Grieco (crítico literário); Afrânio Zucolotto (que depois fez parte, com Paulo Emílio, do conselho da Cinemateca Brasileira); Armando de Salles Oliveira Filho (esteve com Décio e Paulo Emílio no exílio francês deste); Afonso Schmidt (“o único comunista da redação de O Estado de S. Paulo"); Guillermo Renan Hohagen (peruano, amigo de Oswald de Andrade que esteve no Brasil em 1935); Mozart Firmeza (colaborador do Correio de S. Paulo) e João Penteado Stevenson (diretor d'A Platéia), Gilberto e Jorge Amado, entre outros.

No campo político, também aparecem personalidades significativas. Os fundadores da revista convidaram elementos do integralismo para fazer parte da mesma, como "a prova de que nós somos realmente imparciais". Assim, surgem nas cartas Plínio Salgado (fundador do integralismo no Brasil), Francisco Luiz de Almeida Salles (que depois se tornou grande amigo de Paulo Emílio e parceiro na Cinemateca) e Pedro de Toledo (integralista ligado à Faculdade de Direito). Entre os ativistas de esquerda, encontram-se Carlos Lacerda (membro de destaque da ANL), Colbert Malheiros e Osório César (intelectuais brasileiros ligados ao Partido Comunista) e daqueles que seriam os representantes de Movimento pelo Brasil, como Eduardo Sucupira Filho e Sebastião Almeida Oliveira.

Muitos nomes dessa rede vão estar presentes novamente na vida dos dois críticos em outras empreitadas, em outras cartas e em trechos de crítica que produziram, focalizando o teatro e o cinema brasileiro.

Fora do campo intelectual, a rede é também composta de figuras do ambiente pessoal e íntimo dos carteadores, como os colegas do Liceu Nacional Rio Branco, Aquiles de Barros Fontes, Francisco Martiniano Rodrigues Alves Filho, Hugo Nascimento Gama e o professor de português Sr. Gonçalves; do "Cassino", Paulo Afonso de Mesquita Sampaio e Rodolfo de Mesquita Sampaio, Miguel Ferreira da Silva

\footnotetext{
80 “A lição inglesa”. Crítica de cinema no Suplemento Literário, v. 1. Ed. cit., p. 307.
} 
Neto, Gilberto Coaracy, Leônidas e Lenício Pacheco Ferreira e Renato Loureiro; e das famílias Sales Gomes (Chico, Dona Gilda, Sr. Francisco, a empregada Maria) e Almeida Prado (Flávio e Antonio).

\section{"A mocidade brasileira já se movimenta, já estuda, já produz" 81}

A origem da formação intelectual e política da geração de Paulo Emílio Sales Gomes e Décio de Almeida Prado é o assunto do ensaio de Antonio Candido "A Revolução de 1930 e a cultura" ${ }^{\text {}}$. O autor afirma que essa década foi um marco histórico para a sua geração e para o país, ressaltando o papel que a literatura desempenhou ao fornecer elementos para o conhecimento crítico da realidade brasileira. O autor enfatiza, igualmente, a importância das mudanças na educação, considerando a criação da USP, em 1934, que possibilitou o surgimento de carreiras intelectuais menos elitistas.

Essa nova atmosfera favoreceu a criação de Movimento, que pode ser visto como um embrião de um projeto mais consistente e ambicioso (em termos críticos, estéticos e políticos): a revista Clima, que teve seu primeiro número em 1941 e o último em 1944. Acerca da sociabilidade que teria propiciado o nascimento de Clima, Décio de Almeida Prado testemunhou:

Porque os modernistas de 22, quando fizeram a sua revista, Klaxon, eles tinham de 30 anos para mais, quer dizer, eram pessoas já formadas e, adultos literariamente, tinham um projeto, que realizaram, que era o projeto de lançar a modernidade no Brasil. Nós éramos discípulos desses primeiros modernistas. O Clima era mais um problema de relação pessoal do que propriamente de projeto literário, mas acho que, apesar de tudo, nós tínhamos um projeto literário que é aquele projeto meio inconsciente que se tem - ou meio consciente também, conforme o caso -, isto é, nós conversávamos tanto entre nós que possivelmente houve assim uma espécie de ponto em comum, uma certa unidade. Unidade na maneira de ver as coisas. ${ }^{83}$

\footnotetext{
${ }^{81}$ Arquivo Paulo Emílio Sales Gomes/Cinemateca Brasileira, PE/CP 0041.

82 "A Revolução de 1930 e a cultura". A educação pela noite. Ed. cit., p. 219.

${ }^{83}$ A crítica cúmplice - Décio de Almeida Prado e a formação do teatro brasileiro moderno. Ed. cit., p. 300 .
} 
Antonio Candido avalia a importância de Clima, idealizada pelo escritor e teatrólogo Alfredo Mesquita (1907-1986) e pelo crítico de arte Lourival Gomes Machado (1917-1967), considerando que esta possibilitou o desenvolvimento intelectual do grupo. Algumas seções foram inovadoras, sobretudo no que tange ao cinema, porque Paulo Emílio pôde criar um novo tipo de crítica cinematográfica. Além disso, como já mencionado, Paulo Emílio teve uma influência muito importante, a partir de certo momento, na conduta política de sua geração.

Para Décio de Almeida Prado, Clima também exerceu papel fundamental, na medida em que o formou como crítico, já que ficou responsável pela seção de teatro, em uma atribuição dos companheiros do grupo, fato que, segundo ele, direcionou a sua formação profissional: "Durante os cinquenta anos seguintes prossegui, como colega obediente, no caminho que os meus amigos - amigos do coração, é verdade - haviam escolhido para mim, certamente me conhecendo melhor do que eu mesmo me conhecia". 84

\section{"Tenho a impressão de que meus 18 anos duraram anos" 85}

Movimento - revista do presente que enxerga o futuro pode ser vista tanto como laboratório para Clima, quanto espaço de exercício intelectual e político de Paulo Emílio Sales Gomes e Décio de Almeida Prado. Daí a riqueza desse material e dessas cartas que acompanham sua gestação.

O ideário artístico e político presentes na revista desdobram-se nesse conjunto de cartas. Contudo, nas mensagens, ideais políticos, liberdade estética, valorização da arte nacional, convivem com o humor, conquistado, em parte, pela intimidade de seus interlocutores e, em parte, pelas suas próprias índoles. Reside, certamente, nessa ambivalência (seriedade $\times$ lúdico) o fascínio que a correspondência exerce em leitores extemporâneos.

Nas cartas de Paulo Emílio e Décio, vislumbramos a busca pela compreensão do mundo; da política à literatura, passando pela própria definição de identidade. Apesar de serem cartas de dois jovens, ainda confusos diante do complexo mundo que os cercava,

\footnotetext{
${ }^{84}$ ARÊAS, Vilma, AGUIAR, Flávio, FARIA, João Roberto (orgs.). Décio de Almeida Prado - um homem de teatro. São Paulo: Edusp, 1997, p. 435-7.

85 “Um discípulo de Oswald em 1935”. Crítica de cinema no Suplemento Literário, v. 2. Ed. cit., p. 446.
} 
testemunham os passos consistentes de uma formação intelectual que definirá carreiras singulares no campo cultural brasileiro.

Atando as pontas, percebe-se que o material aqui estudado documenta o início de dois percursos de vida interessantíssimos, assim como o espelhamento dos anseios de uma geração.

Temos, assim, uma história dentro da outra: as cartas que contam a história de uma revista, que conta a história de outra(s) revista(s), que conta(m) a história de uma sociedade, da formação de uma geração, da qual fizeram parte dois amigos e correspondentes: Décio de Almeida Prado e Paulo Emílio Sales Gomes.

\section{Esta edição}

O conjunto de 19 cartas (11 de Paulo Emílio Sales Gomes e oito cartas de Décio de Almeida Prado), o exemplar de Movimento - revista do presente que enxerga o futuro, assim como os artigos de jornais que compõem esta dissertação, pertencem ao Arquivo Paulo Emílio Sales Gomes (APESG) da Cinemateca Brasileira.

No trabalho de transcrição fidedigna das missivas segui a norma ortográfica vigente; cumpri a normatização de nomes próprios como "Trotski", "Emílio Sales" e "Aliança"; mantive as palavras estrangeiras, como "Pocker" e "Chic", bem como suas marcações originais (entre aspas e sem); conservei a pontuação e abreviações como "V.", "Qdo", "Gde", “Af.", "Mto", para que o discurso epistolar, marcado pelo currente calamo, não perdesse a sua singularidade. As referências a obras literárias, cinematográficas, teatrais e musicais, assim como título de jornais e revistas, que ao longo da correspondência recebem diferentes marcações, foram normatizados com o uso de itálico. Na impossibilidade de decifração de trechos de cartas, empregou-se a marcação “[ilegível]". Os trechos de textos de Movimento e de outros periódicos, bem como os de outros documentos citados nas notas, também tiveram sua ortografia atualizada.

Dois tipos de anotação acompanham as cartas; a primeira, ao final de cada mensagem, descreve os documentos, para preservar o caráter significativo de sua materialidade (papel, timbre, tinta, rasgamentos etc.) e a segunda, procura fornecer ao leitor uma ambiência, a fim de que os assuntos tratados pelos correspondentes possam ser mais bem compreendidos pelo leitor de hoje. 


\section{As cartas}

\section{(1) DAP}

Campos do Jordão, Abernéssia, Umuarama. ${ }^{86}$ [anterior 20 de junho de 1935]. ${ }^{87}$

Paulo Emílio,

Aí vai este rapaz, que ficou meu amigo aqui em Umuarama e que, como V. pode verificar está bastante trabalhado pelos "camaradas". Não é propriamente comunista, mas bastante simpatizante. Gostou muito do Stálin ${ }^{88}$ que V. me emprestou e além disso tem aqui outros livros de Osório César, ${ }^{89}$ Colbert Malheiros, ${ }^{90}$ etc... Pelo que pude verificar não conhece os "lacaios do imperialismo" mas em compensação tem a coragem de falar em gravidez perto de moça, a respeito da doutrina. Como V. vê está

\footnotetext{
${ }^{86}$ Décio de Almeida Prado (DAP), em "Paulo Emílio quando jovem", testemunha a sua estadia em Campos do Jordão, em 1935: "[...] aceitando o conselho do meu pai, para quem o encargo mais urgente para mim naquele interregno de vestibulares, em que eu passaria de medicina para filosofia, era engordar alguns quilos, viajei para Campos do Jordão, onde permaneci por três meses. Foi lá, através de uma correspondência copiosa e desigual (Paulo escrevia torrencialmente, eu em conta-gotas), que fui sendo informado sobre o andamento da revista [Movimento] e foi lá, de longe, não sem surpresa, que comecei a perceber a importância que o meu companheiro de ginásio principiava a adquirir nos meios intelectuais paulistas." (Seres, coisas, lugares (Do teatro ao futebol). Ed. cit., p. 158-9).

${ }^{87}$ Data atestada segundo a resposta de PE a DAP, em 20 de junho de 1935, na qual ele afirma ter recebido "muito bem o Sebastião Leite".

${ }^{88}$ Referência à biografia Stálin o Czar Vermelho, de Christian Windecke, publicado no Brasil em 1933, pela Editora Nacional, com tradução de Federico Carlos Spicacci.

${ }^{89}$ A relação de Paulo Emílio Sales Gomes (PE) com o médico psiquiatra e intelectual Osório César (1895-1979) estreitou-se através da política. Osório César foi um dos responsáveis pela circulação das ideias comunistas no Brasil no início da década de 1930. Segundo José Inácio de Melo Souza, em sua biografia Paulo Emílio no Paraíso, o psiquiatra fez parte do grupo de intelectuais que viajou para a União Soviética em busca de "conhecimento sobre a realidade desse país". No final de 1935, PE foi preso e prestou seu primeiro depoimento no DOPS, afirmando sua posição esquerdizante. O prontuário de PE historia: "[...] o declarante é amigo do médico Osório César, tendo este oferecido ao declarante dois cartazes um de propaganda do ensino técnico e outro de propaganda contra o imperialismo; que um desses cartazes o declarante ofereceu (sic) pelo Correio enviado pelo doutor Osório César quando este último se encontrava na Rússia; que o outro lhe foi dado pessoalmente por Ósorio César logo após a sua chegada a esta capital; que um desses cartazes o que trata do ensino técnico aplicado na Rússia, o declarante o expôs quando da sua conferência no Sindicato dos Ferroviários da Central do Brasil" (Paulo Emílio no Paraíso. Ed. cit., p. 79). Osório César, responsável pelo Instituto Psiquiátrico do Juqueri, na contracorrente de seu tempo, recusou métodos violentos no tratamento da esquizofrenia. Obras de sua autoria: A arte primitiva dos alienados (1925), Sobre dois casos de estereotipia gráfica com simbolismo sexual (1927) e A expressão artística dos alienados (1929).

${ }^{90}$ Colbert Malheiros (1907-?) conheceu PE na Aliança Nacional Libertadora (ANL), organização política da qual o escritor e tradutor carioca fazia parte. É dele a tradução para o português do livro de Romain Rolland Os que morrem nas prisões de Mussolini (Antonio Gramsci), publicado no Brasil em 1935, provavelmente, sobre o qual comentam na carta.
} 
em bom caminho. Incumbiram-no de se informar a respeito da A.N.L. ${ }^{91}$, para que possa ser fundado o partido em Araraquara, onde, segundo ele informa há muitos adeptos. Espero que V. o ajude o melhor que puder.

Estou lendo atualmente o Stálin. É um livro muito interessante. É pena que o autor tome tanto partido a favor de Stálin e contra Trotski. ${ }^{92}$ Este é visto com evidente má vontade. Apesar disso, o livro me deixou tendo melhor ideia de Trotski do que de Stálin, a respeito de tudo, exceto quanto à decisão e audácia. Acho mesmo que Stálin deve ser melhor chefe que Trotski. Naturalmente essa opinião é baseada somente no tal livro, de modo que é quase completamente sem valor.

Qualquer dia escreverei uma carta maior e então explicarei bem o que quero dizer. Li também o Roberto ${ }^{93}$ e por sinal não concordo absolutamente com o que V. disse. Só se for devido ao fato de ser muito narrado. Estou com bastante interesse em saber o que diz Mário de Andrade ${ }^{94}$ a respeito dele.

\footnotetext{
${ }^{91}$ A Aliança Nacional Libertadora (ANL) foi um movimento de esquerda contra o facismo que surgiu no Brasil em março de 1935 e durou apenas alguns meses; teve grande influência na formação política de PE. Sobre essa formação José Inácio de Melo Souza afirma: "A adesão de PE à ANL alterou a sua trajetória de militante de esquerda. Ele, que nunca se rendera completamente à ortodoxia do Partido Comunista, encontrou na nova organização espaço para aumentar sua participação política.[...] Com a ANL, o discurso de PE encontrará um leito diferenciado, numa radicalidade democrática distinta do discurso comunista”. (Paulo Emílio no Paraíso. Ed. cit., p. 29). PE participou ativamente do movimento; discursou no comício que ocorreu em junho de 1935 e divulgou artigos e entrevistas n'A Platéia, jornal ligado à ANL.

${ }^{92}$ Sobre os livros dos políticos russos Josef Stálin (1879-1953) e Leon Trotski (1879-1940), assim como sobre as divergências entre eles, há referências nos textos de PE e DAP. Em 1935, os dois amigos já procuravam distanciar-se tanto das ideias autoritárias de Stálin, em busca do "socialismo em um só país", como das de Trotski, que pregava a "revolução permanente", numa tentativa de implantação do socialismo pelo mundo. PE, em 1962, no artigo "Potemkin e Outubro" sobre os dois filmes, publicado no "Suplemento Literário" de O Estado de S. Paulo, escreve: "Na realidade histórica, os Bonapartes emanam do cerne da Revolução. Mais tarde Trotski foi politicamente liquidado sob a acusação de pretender ser o Napoleão da Rússia e em última análise, esse papel coube a Stálin, mas isso já é assunto diverso" (Crítica de cinema no Suplemento Literário, v. 2. Ed. cit., p. 399). DAP também refletiu sobre essa relação em seu artigo "Tentativa de crônica sobre Rubem Braga": "Entre o stalinismo e o trotskismo buscava-se uma terceira via, isenta dos vícios inerentes aos sistemas ditatoriais". (Seres, coisas, lugares (Do teatro ao futebol). Ed. cit., p. 89). No período em que transcorre o diálogo epistolar entre PE e DAP, contavam-se títulos de obras de Stálin e Trotski, em edições francesas; de Stálin, vale apontar: Anarchisme ou socialisme? (1907), Le marxisme et la question nationale (1913), Les principes du léninisme (1924), Les questions du léninisme (1931); de Trotski: Bilan et perspectives (1905), Lenine (1925), La revolution défiguré (1929), Histoire de la révolution russe (1930), Ma vie (1930), L'internationale communiste après Lénine (1930), La révolution permanente (1931) e Histoire de la révolution russe (1932-1933).

${ }_{93}^{93}$ Roberto, romance de Sérgio Milliet, publicado pela editora L. Niccolini \& Cia, em 1935.

${ }^{94}$ Mário de Andrade (1893-1945), polígrafo da geração modernista, admirado por PE e DAP. Em 1964, PE sintetiza a importância do autor de Macunaíma (1928) em sua formação intelectual: "O nome de Oswald de Andrade tinha para mim enorme prestígio. Como o de Mário de Andrade. [...] eram as figuras principais do modernismo brasileiro [...]". ("Um discípulo de Oswald em 1935". Crítica de cinema no Suplemento Literário, v. 2. Ed. cit., p. 441).
} 
Li o Patrocínio e Crítica ( $3^{\mathrm{a}}$ série) de H. Campos e vou fazer uma notícia dos dois. A do Patrocínio está quase pronta e a da Crítica falta passar ao papel. Assim que ficar pronto mandarei a V. ${ }^{95} \mathrm{O}$ artigo não sei se dará tempo. Vou fazer o possível.

A respeito do casamento, ${ }^{96} \mathrm{eu}$, apesar de acreditar, conservo o sorriso preventivo do pessoal do Murilo... Confio, desconfiando.

Achei muito interessante a sua carta. M. de Andrade disse da necessidade dos intelectuais brasileiros se mostrarem em pijama, em suas cartas. ${ }^{97}$ Você, sempre exagerado, logo se mostrou em cuecas.

Temos apreciado bastante os freges entre integralistas e aliancistas. Compramos mesmo um número da Manhã ${ }^{98}$ estupendo.

Qualquer dia vai uma carta a Você, as duas notícias dos livros, uma carta ao Miguel $^{99}$ e outra ao Paulo Afonso, ${ }^{100}$ fora algumas fotografias, tudo num envelope grande endereçado a V. Assim o Cassino ${ }^{101}$ terá notícias de todos os meus passos. Escrevam-me. V. recebeu meu cartão? Receba bem o rapaz que leva esta. O nome dele é Sebastião Leite Ribeiro de Carvalho. ${ }^{102}$ Recado do

Décio.

\footnotetext{
${ }^{95}$ DAP, no primeiro número de Movimento, dedicou resenha crítica aos livros Patrocínio - O tigre da abolição, 1935, de Osvaldo Orico, biografia de José Carlos do Patrocínio (1853-1905), e Crítica (3 ${ }^{a}$ série), 1935, de Humberto de Campos.

${ }^{96}$ Refere-se ao casamento de Melo Jorge e Nely, amigos de DAP e PE.

${ }^{97}$ Referência, certamente, ao trecho do artigo "Amadeu Amaral", de 24 de dezembro de 1939, em que Mário de Andrade tece comentários sobre o gênero epistolar no Brasil: "Mas cartas com assunto, falando mal dos outros, xingando, contando coisas, dizendo palavrões, discutindo problemas estéticos e sociais, cartas de pijama [...] só mesmo com o modernismo se tornaram uma forma espiritual de vida em nossa literatura". Curiosamente, o emprego da expressão em 1935, mostra que ela já era conhecida no campo literário. (ANDRADE, Mário de. O empalhador de passarinho. São Paulo: Martins/INL-MEC, 1972, p. 182-3).

${ }^{98}$ Possível referência ao jornal oposicionista A Manhã , editado no Rio de Janeiro, que circulou de 1926 a 1935 , tendo entre os redatores o escritor Jorge Amado.

${ }^{99}$ Miguel Ferreira da Silva Neto, amigo de PE e DAP. Conheceram-se no Liceu Nacional Rio Branco e faziam parte do "Cassino". Por meio da correspondência de PE fica evidente o laço estreito entre eles e a colaboração de Miguel na feitura de Movimento, que teria, em seu segundo número, um artigo dele, "Livre câmbio e protecionismo". Foi na casa desse amigo de família conservadora que PE se escondeu após fugir da prisão, em 1937, condenado por subversão política.

${ }^{100}$ Paulo Afonso de Mesquita Sampaio, primo do interior de DAP. Fazia parte do "Cassino" e logo ficou muito amigo de PE. Foi o responsável pela gerência de Movimento. Ele será citado nas cartas como "P.Afonso", "P.Af." ou "P.A".

${ }^{101}$ A casa da família Sales Gomes, à rua Dr. Veiga Filho, 323, no bairro de Higienópolis, ficou conhecida como "Cassino", pois abrigava um grupo de jovens que se reunia semanalmente para jogar pôquer e discutir política e cultura.

${ }^{102}$ Sobre Sebastião Leite Ribeiro de Carvalho e sua condição de representante de Movimento na cidade de Araraquara, há no Arquivo de PE, na Cinemateca Brasileira, uma carta dele para PE de 1 de agosto de 1935, vinda de Araraquara. Nela, solicita mais números da revista para propaganda e pede informações sobre o preço e a periodicidade desta; informa que a revista vinha tendo grande procura e que havia comentários de que ela talvez tivesse vida curta. (Arquivo Paulo Emílio Sales Gomes/Cinemateca Brasileira, PE/CP 0042).
} 
Carta sem data; autógrafo a tinta preta; papel branco; 2 folhas; $28 \times 21,5 \mathrm{~cm}$; manchas por oxidação; 2 furos.

(2) PE

São Paulo, 20 de junho de 1935.

Caro Décio -

Conforme sua insistente recomendação recebi muito bem o Sebastião Leite. Ontem marquei com ele um encontro na Aliança, mas foi-me impossível ir. Espero um telefonema dele. Ficou sendo o representante de Movimento em Araraquara. ${ }^{103}$

Logo que comecei a escrever essa carta ${ }^{104}$ uma baita vespa veio me atrapalhar. Como tenho muito medo desse bicho, antes de matá-lo não sosseguei. Imagine que cúmulo a atitude das vespas daqui de casa. Vieram construir o enxu bem no candelabro do meu quarto. Hoje resolvi desalojá-las. Fiz isso agora há pouco. O Miguel e o Paulo Afonso, que saíram há uns 5 minutos (estou escrevendo às $2 \mathrm{~h}$ da manhã) estavam distraidamente aqui no meu quarto qdo eu entrei com uma tocha para matar as vespas. $\mathrm{O}$ Miguel, que lia sua carta deitado na cama, só percebeu a história quando as vespas estavam feito umas desesperadas, voando pelo quarto. Você precisava ver o terror dele. Meteu-se debaixo das cobertas aos berros, mandando apagar a luz, me xingando,

103 PE instituiu diversos representantes de Movimento pelo Brasil. Em seu Arquivo na Cinemateca Brasileira, há cartas que ilustram esse fato, como aquelas trocadas com Eduardo Sucupira Filho, representante da revista em Santos, e com Sebastião Almeida Oliveira, em Tanabi, no interior de São Paulo. Eduardo Sucupira Filho escreve a PE em 10 de agosto de 1935: "Com referência à sua sugestão de me tornar aqui em Santos representante da revista Movimento é uma distinção que muito me honra e a respeito, conversaremos mais detalhadamente quando vier a Santos. [...] aguardo a sua vinda a Santos, onde eu o receberei com o maior prazer a fim de trocarmos ideias e concretizarmos o que seja necessário em prol de Movimento, ou outra cousa qualquer do interesse das massas trabalhadoras." Sebastião Almeida Oliveira, pela vez dele, dirige-se a PE em 28 de agosto de 1935: "Quanto à representação de vossa revista nesta cidade, estou ao vosso dispor, mas de antemão vos digo que o campo é deveras restrito; contai, porém, com minha assinatura e boa vontade". (Arquivo Paulo Emílio Sales Gomes/Cinemateca Brasileira, PE/CP 0046 e PE/CP 0048).

${ }^{104}$ Primeira página da carta reproduzida no Anexo. 
implicando contra as vespas e discutindo com o P. Afonso que querendo se esconder também, puxava as cobertas para o seu lado. Foi uma pândega!

O Cassino tem-se reunido regularmente. Sábado passado esteve uma pândega. Imagine que a propósito de umas fotografias, armamos uma discussão exaltadésima sobre força de inércia. Eu e P. Afonso de um lado e Francisco e Emusko de outro. O Rodolfo, imparcial, mas com simpatias pelo segundo grupo. ${ }^{105}$ Foi até duas horas da manhã o berreiro. Quase houve choro de minha parte. Também aquilo estava um verdadeiro tribunal... Acabado o frege o Francisco foi se deitar e nós outros nos entretivemos numa palestra leonidesca, até mais de 4 horas da manhã, sobre sinos e cinema antigo... Nessa ocasião pegamos o P. Afonso numa sensacional malandragem. Imagine que ele disse, que tendo assistido O fantasma da ópera ${ }^{106}$ com 7 anos até hoje se lembrava da fita com todos detalhes. E de fato pelas descrições que ele fez, parecia mesmo. Descobrimos depois que esse refrescamento de memória tinha sido ocasionado por uma reprise que surgiu aqui em S. Paulo em 1933. Foi um escândalo...

Hoje aqui em casa houve grandes debates. Eu não assisti porque jantei em casa do Miguel. A polêmica foi feita por P. Afonso, Francisco e Emusko contra o destreinado e inocente Bolívar. O Bolívar viu fogo. Falou-se sobre tudo - medicina, arte moderna, arquitetura, Fernando de Magalhães, comunismo, Deus, tradição, casamento etc, etc, etc. Como você vê deve ter estado interessantíssimo.

A conclusão foi que o Bolívar era um atrasado e não compreendia o século. Imagine só Décio. E nenhum de nós estava presente! Esta gente está ficando terrível, não?

\footnotetext{
105 O "Cassino" era formado por PE, seu irmão Francisco Guilherme Sales Gomes, DAP, seu irmão Flávio de Almeida Prado, Paulo Afonso de Mesquita Sampaio e Rodolfo de Mesquita Sampaio, primos de DAP do interior de São Paulo, Miguel Ferreira da Silva Neto (amigo do Liceu Nacional Rio Branco), Gastão e Gilberto Coaracy, Leônidas e Lenício Pacheco Ferreira e Renato Loureiro. Esta era a formação "fixa" do grupo, contando eventualmente com outros jovens da mesma geração.

${ }^{106} \mathrm{O}$ filme $O$ fantasma da ópera, baseado no romance homônimo de Gaston Leroux, teve a primeira versão para o cinema em 1925 , sobre a qual comentam na carta.
} 
Acho perfeitamente natural que você goste mais do Trotski que do Stálin. Concordo que não haja comparação possível entre um e outro no campo intelectual, não querendo absolutamente dizer com isso que Stálin seja burro. Não! Ele é inteligente, e muito. Certas passagens de sua vida e mais do que isso, o seu livro sobre leninismo, ${ }^{107}$ provam isso. Também tenho mais simpatia pessoal pelo Trotski. Ele me parece mais humano, mais latino, do que o Stálin que é mesmo frio como o aço. Além disso, Trotski é mais sensível em relação às artes, e isso para nós, é muito importante, Décio. Trotski se preocupa com literatura e dá opiniões e mais opiniões sobre músicas, quadros etc. Stálin ouve a Aída, porque lhe dá uma boa sensação, e só. Não sabe dizer mais nada. ${ }^{108}$ Lê Daudet ${ }^{109}$ e gosta do Tartarin, porque “é um ótimo tipo, quase cientificamente retratado, de pequeno burguês". Suas pilhérias são aquelas de que o Windecke fala no livro. Foram essas coisas todas que me fizeram um dia lhe dizer (há mais tempo) ser eu trotskista. Mas hoje, tendo em vista um chefe de uma ditadura de proletariado não hesito mais em ser decididamente do lado de Stálin. Defendo Trotski mas não deixo de considerá-lo nefasto, atualmente, à Revolução. Creio, entretanto, que é sincero.

Eu imagino só o seu sorriso de simpatia quando você leu que o Trotski por deboche, passava as seções do P.C.R. folheando romances franceses... ${ }^{110}$ Você precisa ler Ma vie. É um livro notável. ${ }^{111}$

\footnotetext{
${ }^{107}$ Refere-se às conferências dadas por Stálin em Praga, 1924, e depois, em 1931, publicadas no livro Les questions du léninisme, pela Éditions Sociales et Internacionales.

${ }^{108}$ Sobre a discussão entre o pensamento de Trotski e Stálin, DAP, no ensaio "Paulo Emílio quando jovem", elucida: "Fora com ele [PE] à casa de Mário de Andrade e assistira com uma certa emoção de iniciante a uma conversa sobre stalinismo e trotskismo em que os meus dois interlocutores - e por isso o diálogo gravou-se em minha cabeça - concordavam que se tratava de uma discórdia puramente interna, dizendo respeito apenas à Rússia e que não devia repercutir sobre a esquerda brasileira". (Seres, coisas, lugares (Do teatro ao futebol). Ed. cit., p. 158).

109 Alphonse Daudet (1840-1897), escritor francês, criou o herói Tartarin, personagem das novelas Tartarin de Tarascon (1872) e Tartarin sur les alpes (1885).

${ }^{110}$ As leituras de PE, principalmente de cunho político, intensificaram-se nos anos de 1934 e 1935. Sobre essas leituras, recuperam-se testemunhos relevantes na obra de PE. No depoimento a Mário Neme, em 1945, para a Plataforma da nova geração, afirma: "O marxismo em vigor era, em sua maioria, constituído de teses e documentos de congressos e conferências da Internacional, particularmente resoluções sobre o problema dos países semicoloniais e visões esquemáticas da questão do imperialismo inglês e norte-americano. Além do Manifesto, um Bukarin ou Plekanov, e o Estado e a revolução, quase não se liam os clássicos [...]" (Plataforma da nova geração. Ed. cit., p. 285). Em "Um mundo de ficções", de 1960, publicado no "Suplemento Literário" de $O$ Estado de S. Paulo, PE refere-se às brochuras da Internacional: "Comunista que eu era, minha interpretação dos acontecimentos da vida política brasileira processavam-se através das brochuras editadas em espanhol pela Terceira Internacional em Moscou. (Crítica de cinema no Suplemento Literário, v. 2. Ed. cit., p. 296). Sobre as leituras da obra de Stálin, PE relata, em 1964, no mesmo suplemento: "Eu sobraçava um volume intacto de Les questions du léninisme de J. Stálin das Editions Sociales et Internationales. Roland, olhos brilhantes, me concitava a ler Alberto Torres. Oswald defendia minhas leituras afirmando que o livro de Stálin era o De Bello Gallico do século vinte". (“Um discípulo de Oswald em 1935". Crítica de cinema no Suplemento Literário, v. 2. Ed. cit., p. 441). Antonio Candido também escreveu sobre as leituras políticas de PE nesse período, em "Paulo Emílio: a face política": "Como equipamento levava o que poderia ter aprendido no parco arsenal daquele
} 
A revista como você vê pelo papel em que escrevo, vai otimamente. ${ }^{112}$ Já está nas provas. Vê se dá para mandar o seu artigo para o primeiro número. Pelo menos é mais garantido... Meu estudo (“A posição do artista revol. na soc. burguesa”) já foi aprontado e já está na tipografia. ${ }^{113}$

Pretendia lhe escrever muito mais mas estou com sono. Logo que receba sua carta escreverei outra com mais notícias.

Grande Abraço do

\section{Paulo Emílio}

P.S. O Melo casou-se mesmo.

P E

Carta datada: "S. Paulo - 20 - junho - 1935"; autógrafo a tinta azul; papel branco, timbrado: "MOVIMENTO - revista do presente que enxerga o futuro"; 8 folhas; $28 \times 21 \mathrm{~cm}$.

\section{(3) PE}

São Paulo, 23 de junho de 1935.

\section{Caro Décio}

Eu mesmo é que estou escrevendo.

tempo: Manifesto de Marx e Engels; resumo d'O Capital por Gabriel Deville; Anti-Dühring de Engels; Questões fundamentais do marxismo de Plekanov; $A B C$ do comunismo de Bukarin; Dez dias que abalaram o mundo de John Reed; livros de viagem à União Soviética. A isto somava certa informação sobre o aprismo e muito entusiasmo pela Revolução Mexicana [...]". (Vários escritos. Rio de Janeiro: Duas Cidades/Ouro sobre Azul, 2004, p. 253-4). Nesse trecho da carta PE faz, ainda, menção ao PCR, partido comunista russo, do qual Trotski fez parte.

${ }_{111}^{11}$ Refere-se à autobiografia de Trotski, Ma vie, editada em francês pela Éditions Rieder, em 1930.

${ }^{112}$ A carta é escrita em papel timbrado de Movimento.

113 "A Posição do artista revolucionário na sociedade burguesa (a propósito da morte de Facio Hebequer)", artigo de PE em Movimento. 
Por isso a única novidade que lhe conto é que os amigos andam alarmados com a série de cartas que ando lhe escrevendo. Estão só esperando suas cartas a fim de lhe mandarem oportunas e apressadas retificações...

Mando-lhe minha última entrevista... O intróito sobre moços estudiosos etc..., e o retrato do Gilberto foram por conta do Mozart Firmesa, crítico musical do Correio de S. Paulo e meu camarada. ${ }^{114}$

Onde estão suas famosas cartas dentro de já lendários envelopes?

Isso já é desaforo. Ou será incompetência? Você será que ainda não encontrou nos 4 livros que leu alguma coisa interessante para sapecar entre aspas num papel de cartas, e me mandar?

Creio, pelo dito acima, que tenho garantida uma fornada de cartas.

Um forte abraço do

\section{Paulo Emílio}

P.S. - Não repare no mau estilo. Esse bilhete foi rapidamente rabiscado e nem sequer corrigido... ${ }^{115}$

Posso te adiantar que o novíssimo que fará a segunda conferência (veja recorte anexo) é você. ${ }^{116}$ Mande sua opinião a respeito.

Carta datada: "S. Paulo, 23 - junho 1935"; datiloscrito original a fita preta; autógrafo e PS. a tinta azul; papel branco; 1 folha; $26,2 \times 20,5 \mathrm{~cm}$.

\footnotetext{
${ }^{114}$ Entrevista concedida a Mozart Firmeza para o jornal Correio de S. Paulo, em 21 de junho de 1935. Apresenta o retrato de Gilberto Amado e a legenda "Gilberto Amado iniciará as conferências de Movimento".

${ }^{115} \mathrm{O}$ "bilhete" está datilografado e essa observação, no final da página, manuscrita com a letra de PE.

${ }^{116}$ Post scriptum colocado no topo da página. No anexo, recorte do Correio de S. Paulo, de 21 de junho de 1935, PE afirma: "Temos esperança de que Movimento seja um núcleo de uma futura organização cultural. Faremos conferências, organizaremos exposições de quadros, tournée, teatro escola, e mais experiência interessantes. Temos também em mente a fundação de cursos de psicofísica, arte moderna, metafísica literária, arquitetura de salão, além de literatura, línguas, sociologia, etc. Nosso curso de conferências será iniciado por Gilberto Amado, que virá brevemente a S. Paulo. A segunda será confiada a um novíssimo".
} 
(4) DAP

Umuarama, 5 de julho de 1935.

Paulo Emílio

É realmente lamentável que o Paulo Afonso use, entre amigos, processos indecorosos para aparentar memória que na realidade ele não tem. Principalmente quando isso de memória é cá conosco.

Soube pelo Paulo Afonso que outro dia você falou num comício da Aliança ${ }^{117}$ e fiquei com curiosidade de saber se a célebre frase: "e aquele que provar ter sido ele etc...", foi usada e admirada. É favor você mandar contar o sucesso da falação e mandar também as duas entrevistas sobre Movimento ${ }^{118}$ (Rodrigues Alves está vingado). ${ }^{119}$

Esta carta está mal escrita porque eu não tenho o hábito de ditar e nem ela de fazer ditado. ${ }^{120} \mathrm{O}$ resto referente a isso contarei em São Paulo.

Vai com esta carta as duas notícias prometidas sobre o Patrocínio e a Crítica de Humberto de Campos. Vai também um recorte sobre Trotski que uma gentil senhorita teve a bondade de me dar. ${ }^{121} \mathrm{O}$ artigo não vai por falta de tempo e assunto.

\footnotetext{
${ }^{117}$ Apesar de não haver registro na imprensa do comício da ANL em junho de 1935, segundo o biógrafo José Inácio de Melo e Souza é provável que PE tenha discursado com muita coragem e animando a plateia de seis mil pessoas. (Paulo Emílio no Paraíso. Ed. cit., p. 31).

${ }^{118}$ As duas entrevistas de PE sobre Movimento citadas apareceram n'Correio de S. Paulo, em 21 de junho de 1935, e no Diário da Noite, em 29 de junho de 1935.

${ }_{119}$ Conselheiro Rodrigues Alves (1848-1919) presidente do Brasil de 1902 a 1906. Foi para Monteiro Lobato: "[...] o tipo da atualidade, com os defeitos e falhas". (LOBATO, Monteiro. "Cons. Rodrigues Alves". Críticas e outras notas. São Paulo: Brasiliense, 1969, p. 180).

${ }^{120}$ Não se sabe quem é "ela". A carta é manuscrita com letra diferente da de DAP, provavelmente desta mulher.

${ }^{121}$ Recorte não localizado pela pesquisa.
} 
O livro do Windecke é visivelmente contra Trotszki. Assim ele escreve a opinião da irmã de Lenine (válida pelo fato de contrastar com a interpretação de Trotski). Quer dizer que basta ser contrário a Trotski para tornar-se verdade na opinião de Windecke, o que demonstra imensa má vontade. Esse é um exemplo dos muitos que há no livro. (Qual será a interpretação do $s$ a mais que mandei por na palavra Trotski. ${ }^{122}$ Espero esclarecimentos psicanalíticos). ${ }^{123}$

Tive um sonho muito interessante. Tinha ido à casa do René Thiollier ${ }^{124}$ pedir dinheiro para o Movimento. Ele perguntou se eu tinha lido os livros dele e eu menti que sim. Ele então me contou tristonhamente a tragédia de sua vida de escritor: todo o mundo como eu mentia que tinha lido os livros dele, mas na realidade ninguém lera. $\mathrm{E}$ apesar disso todos eram concordes em afirmar que os livros eram muito infantis somente porque ele era rico e muito educado. Criou-se contra mim, contou-me ele, tal prevenção que hoje ninguém me lê e no entanto tenho consciência de que sou um bom escritor. E terminou pedindo por favor que eu lesse o livro que ele me tinha dado.

Não gostei muito da Vida de George Sand. ${ }^{125}$ Além de ser muito resumida o livro tem o defeito de ser baseado quase todo o tempo sobre as memórias da própria George Sand que logicamente deviam ser suspeitadas.

\footnotetext{
${ }^{122}$ DAP escrevia, em suas cartas, "Trotzki”; PE, "Trotzky". Na transcrição das cartas, normatizei "Trotski".

${ }^{123}$ Fica evidente que os dois já haviam entrado em contato com a obra de Sigmund Freud, possivelmente por meio de edições francesas de A interpretação dos sonhos. PE começa seu ensaio "Um discípulo de Oswald em 1935" afirmando: "Lá pelos dezoito anos tudo, com exceção do cinema e de qualquer ciência exata, me interessava tão vivamente quanto confusa e superficialmente: política, literatura, psicanálise, teatro, arquitetura, sociologia, pintura. O critério era um só. Tudo que me parecesse moderno tinha valor." (Crítica de cinema no Suplemento Literário, v. 2. Ed. cit., p. 440).

${ }^{124}$ René Thiollier (1884-1968), advogado formado pela Faculdade de Direito do Largo São Francisco; membro da Academia Paulista de Letras; colaborou no patrocínio da Semana de Arte Moderna, em 1922.

${ }^{125}$ Refere-se à biografia de George Sand, The search for love, escrita por Marie Jenney Howe e publicada pela editora americana Garden City Publications, em 1928.
} 
Aí vão umas fotografias minhas nas quais apareço mostrando os dentes, fato inédito na minha galeria de retratos. ${ }^{126}$ Peça ao Paulo Afonso que as mostre em casa e depois as guarde. Numa delas estou sobre o "Itapeva" no tal passeio que falo na carta para o Miguel.

E do Leônidas, ${ }^{127}$ não há notícias?

Resta dizer que achei muito interessante a notícia da minha conferência, não sei se verdadeira. A carta não vai muito grande porque tenho pressa de mandá-la. Lembranças a D ${ }^{a}$ Gilda, Emusko, Rodolpho, Chico e D[r]. Sales. ${ }^{128}$ Diga ao Miguel para quando encontrar o Adalberto não se esquecer de dar especiais recomendações minhas ao Queiroz. Espero que sua resposta seja mais interessante que esta carta. A "Prainha" já degenerou ou continua só para uma pequena elite?

Encontrei aqui uma irmã do Dr. Stevenson, ${ }^{129}$ bastante parecida com ele. Contou que o Carlos, ${ }^{130}$ um dos chefes da Aliança fica danado quando o chamam de comunista.

Lembranças ao Coaracy ${ }^{131}$ e você receba um abraço do amigo

\section{Décio}

Carta datada: "Umuarama, 5- 7-1935"; autógrafo a tinta preta; papel branco; manchas por oxidação; 2 folhas; $28 \times 21,5 \mathrm{~cm} ; 2$ furos.

\footnotetext{
${ }^{126}$ Fotografias não localizadas pela pesquisa.

${ }^{127}$ Leônidas Pacheco Ferreira, irmão de Lenício Pacheco Ferreira e conhecido como Donda. Da turma do "Cassino", morava no Rio de Janeiro e ajudou na difusão de Movimento nessa cidade, como relata no trecho, a seguir, extraído de uma carta sua para PE, em agosto de 1935: "Apesar das suas recomendações de máxima urgência, só agora estou agindo em prol da revista. Já levei ao Lins do Rego na redação da Manhã e ao Mauricio de Medeiros na Revista Contemporânea". (Arquivo Paulo Emílio Sales Gomes/Cinemateca Brasileira, PE/CP 0049).

${ }^{128}$ Dada a amizade, desde a infância, entre os dois, DAP conhecia bem a família de PE. Aqui, envia lembranças à mãe de PE, Gilda Moreira de Sales Gomes, ao pai, o médico Dr. Sales, ao irmão Francisco Guilherme, conhecido como Chico e apelidado por PE de Eme e aos amigos Emusko e Rodolfo de Mesquita Sampaio.

${ }^{129}$ João Penteado Stevenson, um dos fundadores e diretores do periódico aliancista A Platéia.

130 Carlos Lacerda (1914-1977), político carioca e membro importante da ANL e da Juventude Comunista. PE, no artigo "Um discípulo de Oswald em 1935", de 1964, rememora como o conheceu: "O importante porém era quando Oswald me conduzia à redação e às oficinas de $A$ Manhã de Pedro Motta Lima, órgão oficioso da Aliança Nacional Libertadora, a expressão política legal do esquerdismo brasileiro. Lá conheci paginando o jornal [...] um jovem como eu, Carlos, filho de Maurício de Lacerda, o tribuno da Aliança Liberal que acabava de aderir à Aliança Nacional Libertadora". (Crítica de cinema no Suplemento Literário, v. 2. Ed. cit., p. 443).

${ }^{131}$ Gilberto Coaracy, amigo de DAP e PE dos tempos de colégio e integrante do "Cassino".
} 
(5) DAP

[Campos do Jordão, posterior 5 de julho de 1935]. ${ }^{132}$

Paulo Emílio,

Aí vai mais algumas notícias que esqueci:

A minha voz causa grande sucesso aqui. Todos elogiam o ouvido afinado e a voz forte e sobretudo agradabilíssima. Creio que agora cessarão comparações entre a minha e a sua voz. É com isso que eu respondo as intrigas que V. e o seu Gonçalves andaram tecendo a meu respeito em cafés afim de saciar o desejo que possuem de emporcalhar reputações, ${ }^{133}$ desejo esse ditado pela mais vil inveja (estilo do Correio Paulistano). ${ }^{134}$

Dei outro dia uma terrível rata. ${ }^{135}$ Ao ver um retrato dependurado na parede, visitando a casa de um amigo, virei-me para ele e disse com ar de esperto:

- Aposto que aquele retrato é da mãe de seu pai.

- Não, é de papai quando era moço, respondeu o pobre rapaz imensamente sem jeito.

\footnotetext{
${ }^{132}$ Data atestada pela referência, na mensagem, ao envio da "notícia do Patrocínio", assunto tratado na carta anterior, de 5 de julho de 1935.

${ }^{133}$ DAP e PE se conheceram ainda meninos no Liceu Nacional Rio Branco. A amizade na escola se fez rapidamente e passaram a frequentar os mesmos grupos, tanto na vida escolar, como fora dela. Antes de Movimento, fizeram juntos algumas publicações literárias ginasianas, como testemunha DAP: "Os cinco anos de ginásio consolidaram entre nós uma amizade que se exprimia através de infindáveis e acaloradas discussões a propósito de nada (uma vez, sobre sangue arterial e sangue venoso, berramos hora), da publicação de jornaizinhos estudantis que nunca passavam do primeiro número e de um suposto estudo em comum [...]". ("Paulo Emílio quando jovem". Seres, coisas, lugares (Do teatro ao futebol). Ed. cit., p. 155). Uma das características que acompanhou PE desde a mocidade era o poder da oratória. No colégio, sempre o escolhiam para discursar nas palestras e confraternizações. Uma voz forte e impotente fez PE ser conhecido como exímio cantor, tanto pela família, como pelos amigos. Sobre esse dado, foi localizado o programa do "Festival em benefício da Villa de São Vicente, a realizar-se no Cine Central, no dia 28 de Maio de 1935", composto de muitas atrações musicais, entre elas "Song of the vagabons - barítono Paulo Emílio Sales Gomes" e "Marcha dos granadeiros - barítono Paulo Emílio Sales Gomes". DAP, entretanto, afirmou que ele cantava com muita força, com graça, mas nunca sabia as letras completas. PE empregou os seus dotes de orador nos comícios políticos iniciados em 1934.

${ }^{134}$ O Correio Paulistano começou a circular em São Paulo no ano de 1854 e foi um dos únicos jornais a apoiar a Semana de Arte Moderna de 1922.

${ }^{135}$ No texto da carta se lê "data".
} 
Verifique se o negócio que ponho sobre a maleita na notícia do Patrocínio está certa. ${ }^{136}$ Qualquer boa modificação que V. quiser fazer em meus artigos pode. Até não publicá-los. Aproveitei nos dois coisas que você me disse.

Peça ao Paulo Afonso que diga em casa que vou bem e que logo escreverei. ${ }^{137}$

Do amigo

Décio

Carta sem data; autógrafo a tinta preta; papel branco; manchas por oxidação; 2 folhas; $28 \times 21,5 \mathrm{~cm} ; 2$ furos.

(6) PE

São Paulo, 11 de julho de 1935.

\section{Caro Décio}

Escrevo-lhe de volta da tipografia onde fui entregar as provas finais da revista.

Mando-lhe só este bilhete porque agora ando com tanta coisa para fazer que já estou tonto. Só a "cozinha" "138 me levou 4 dias inteiros (não é força de expressão) de trabalho. Eu rascunhava, Lenício ${ }^{139}$ passava à máquina, Paulo Afonso corrigia e eu

\footnotetext{
${ }^{136}$ DAP termina sua resenha sobre a biografia de Patrocínio corrigindo o autor, Osvaldo Orico, no que tange ao modo como a malária se instala no doente.

${ }_{137}$ Paulo Afonso de Mesquita Sampaio, primo de DAP, tinha contato diário com PE, daí o pedido para avisar à família Almeida Prado que tudo estava bem em Campos de Jordão. A família de DAP era constituída pelo pai, Antonio de Almeida Prado (conhecido médico de São Paulo que apreciava as artes, sobretudo teatro e literatura), e pelos dois irmãos, Beatriz e Flávio. A mãe, Zilda Junqueira, morreu quando DAP tinha dois anos.

${ }^{138}$ PE foi o responsável por quase toda a "cozinha" de Movimento: a seleção e elaboração de muitos dos textos, datilografia; acompanhamento das provas na tipografia, revisão, paginação; pagamento da gráfica e divulgação. Testemunha DAP: "[...] a revista pertencia inteiramente a PE. Dele eram a ideia, o lema (ou slogan publicitário), o Manifesto inicial, a escolha dos colaboradores, a organização do número, o trabalho decorrente da impressão e correção de provas (tarefa desempenhada também por amigos), e, sobretudo, o dinheiro gasto no empreendimento (dois contos de réis [...])". ("Paulo Emílio quando jovem”. Seres, coisas, lugares (Do teatro ao futebol). Ed. cit., p. 158).

${ }^{139}$ Lenício Pacheco Ferreira, irmão de Leônidas Pacheco Ferreira, amigo de "Cassino" e braço direito de PE na elaboração de Movimento.
} 
revia. No fim Paulo Afonso e Lenício não paravam de brigar e eu berrava exaltadamente para os dois, tal o escangalhamento de nervos em que fiquei. Além disso estou fazendo com o Alayon um trabalho sobre padrão de vida material e estado intelectual do operário de S. Paulo. ${ }^{140}$ Você verá notícia na revista.

Você não recebeu a entrevista que concedi ao Correio de S. Paulo?

Responda logo para eu saber o que lhe mandar.

Cá recebemos sua batelada.

Qualquer dia lhe escrevo uma carta.

\author{
Abraço do \\ Paulo Emílio
}

Cartão datado: "S.P. - 11- 7- 1935"; autógrafo a tinta preta; papel branco, pautado; 1 folha; $19 \times 12,5$ cm; selo/carimbo. Postagem: Campos do Jordão, 11 jul. 1935.

\footnotetext{
${ }^{140}$ PE e DAP estudaram juntos na adolescência, quando vestibulandos para a Escola Paulista de Medicina; $\log$ viram que não teriam futuro na carreira de seus pais, como explica DAP: "Durante um breve período iríamos fingir que estudávamos para medicina, não obstante a nossa inapetência pelas ciências da natureza. Eu fingia com uma certa aplicação, no limite das minhas frágeis forças. PE, com extrema displicência. Limitou-se, a partir de um certo momento, a intitular-se, ocasionalmente, 'acadêmico de medicina', passando por cima dos horríveis vestibulares como num sonho". ("Paulo Emílio quando jovem". Seres, coisas, lugares (Do teatro ao futebol). Ed. cit., p. 155). Nesse período, PE conheceu Fernando Alayon. Os dois fizeram juntos uma pesquisa sociológica, divulgada em Movimento, sob o título "Vida do operário em S. Paulo". Na apresentação do texto se lê: "Fernando Alayon e Paulo Emílio, estudantes de medicina, fazem atualmente um estudo sobre o nível de vida do operário na capital de S. Paulo. Já foi feito pelo Dr. Horace B. Davis, professor catedrático da Columbia University, e contratado para a Escola Livre de Sociologia e Política de S. Paulo, um trabalho nesse sentido, mas abordando unicamente o padrão de vida material dos operários. Nesse estudo os dois acadêmicos de medicina se interessam também pelo estado intelectual do proletário e traçam, sempre que possível, um paralelo entre a vida material e moral, pretendendo inquirir até que ponto há influência da segunda sobre a primeira. Esse estudo está sendo feito pelo meio estatístico e com grande honestidade. Logo que terminado será publicado em primeira mão por Movimento." (Movimento, p. 43). Um mês após essa carta, PE concedeu extensa entrevista sobre o estudo para o jornal A Platéia, como comentará em carta posterior.
} 
(7) DAP

[Campos do Jordão, posterior 11 de julho de 1935]

\section{Paulo Emílio}

Escrevo esta ${ }^{141}$ apressadamente só para avisar que não recebi nenhuma entrevista. Recebi o seu bilhete e espero logo o Movimento. Escreva logo uma carta com todas as novidades que devem ser muitas. Espero resposta à minha papelada (foi tanta que uma senhora daqui julgou que eu estivesse escrevendo uma novela).

Com o fim das férias os hóspedes todos se foram e estou quase sozinho. Dificilmente arranjarei assunto para cartas. A distração que tenho, fora a leitura, são as cartas de vocês. Diante disso espero que aumentarão [sic] o número delas.

Aproveitando o repouso obrigatório iniciei "a campanha dos 10 quilos". Para isso nutri-me de Ovomaltine, aveia e mel. Estou também andando menos.

Recado do amigo

Décio

Carta sem data; autógrafo a tinta preta; papel branco, marcas por oxidação, timbrado: "Pensão Umuarama - Campos do Jordão - Retiro, recreação, revigoramento, repouso./ Pensão de $1^{a}$ ordem diária módica. /Não se aceitam pessoas que sofram de moléstias contagiosas. /Gerência Dra. Ethel Stockinger. /Informações em S. Paulo telefone 4-2572./Altitude 1750 metros. Ótimo clima./Estação de Estrada de Ferro, Correio, Telégrafo./ Abernéssia - Campos de Jordão./ Telefone - Abernéssia n. 24"; 1 folha; $28,5 \times 21,5 \mathrm{~cm} ; 2$ furos.

\footnotetext{
${ }^{141}$ Carta reproduzida no Anexo.
} 
São Paulo, 16 de julho de 1935.

\section{Caro Décio,}

O Paulo Afonso ficou de passar por aqui hoje às 8.30 para irmos à tipografia empaginar o Movimento. Agora já são 11.30 e ele ainda não chegou. Aproveitando a boa vontade e a boa letra da Luluta, ${ }^{142}$ que veio aqui em casa ter uma seríssima conferência comigo, escrevo-lhe finalmente uma carta no sentido ilimitado em que eu, você e o Mário de Andrade usamos esse termo.

Há dias estando muito cansado li, como sempre faço nessas ocasiões, Os Maias. ${ }^{143}$ Por pouco que não lhe escrevo uma carta cretina, traçando um paralelo entre eu - você e Carlos - Ega. Ia-lhe dizer que como aqueles dois dandys, nós daqui há muito tempo ao fazermos o balanço de nossa vida, havíamos, depois de termos pasmado para a inutilidade de nossa peregrinação, concluir contentes de que, entretanto, havíamos rido bastante. Se a minha apurada autocrítica não se tivesse manifestado em tempo, você a essas horas teria um documento mais interessante do que aquele que eu mandei ao Deraldo logo que cheguei da Bahia. ${ }^{144}$ Mesmo que isso acontecesse creio de que você não se aproveitaria desse lapso, dada a sua proverbial lealdade e ao seu respeito ao

\footnotetext{
${ }^{142}$ Luluta, amiga de PE, frequentadora da casa dele. Por vezes, nas cartas, era ela quem escrevia o que ele ditava.

${ }^{143}$ Os Maias (1888), romance do escritor português Eça de Queiroz (1845-1900), no qual se encontram as personagens Carlos da Maia e João da Ega, foi a primeira grande referência literária de PE. Segundo DAP a amizade dos dois fez-se, também, a partir dos livros: "Mais fortes do que as acentuadas diferenças de temperamento, duas coisas nos aproximava: a mania literária e o fácil riso da adolescência, de que possuíamos reservas inesgotáveis". ("Paulo Emílio quando jovem". Seres, coisas, lugares (Do teatro ao futebol). Ed. cit., p. 156). No arquivo de PE localiza-se o manuscrito, de quatro páginas, datado de outubro de 1933, versão do texto preparado por ele para ser lido no final do curso de oratória. Ele declara: "Caros colegas, quis escolher como tema de meu trabalho para a parte final do concurso de oratória, a exposição rápida e em síntese do que penso da eloquência e da arte de falar em geral. Julgo que assim procedendo tornarei meus métodos e minhas ideias mais conhecidos dos que em mim depositaram a confiança de eleger-me orador da turma para os festejos de nossa formatura. Durante minha rápida exposição, focalizarei incessantemente o imortal Rufino, tipo de 'orador' na acepção pouco lisonjeira do termo, tão magistralmente ridicularizado por Eça de Queiroz [n'Os Maias].” (Arquivo Paulo Emílio Sales Gomes/Cinemateca Brasileira, PE/PI 0063).

${ }^{144}$ Em 1933, PE fez uma viagem à Bahia para visitar o ramo baiano da família Sales Gomes. Sobre o poeta e médico baiano Deraldo Dias de Morais (1896-1943), há referência na novela Cemitério (escrita por PE na década de 1970), obra que tem como tema os tumultuosos anos de 1934 e 35 . O narrador menciona pessoas que conhece na Bahia, entre as quais o "poeta Deraldo". (Cemitério. Ed. cit., p. 44-5).
} 
nosso acordo tácito lacrado com um empate, em 1931, quando estávamos no $3^{\circ}$ ano de ginásio. $\mathrm{O}$ caso de $\mathrm{Sr}$. Gonçalves é isolado e serve para ficarmos quites... ${ }^{145}$

Movimento sofreu há dias um forte golpe. Perdi minha carteira com um conto trezentos e tantos mil réis. Isso, como você pode imaginar acabrunhou tremendamente a redação. O Paulo Afonso está até se tornando cético novamente. Creio, que, entretanto, Movimento sairá (a Luluta foi almoçar) ${ }^{146}$ até os fins dessa semana. Mas foi uma coisa pau, hein? Senti uma impressão de vácuo interior muito cacete. Depois refleti sobre a importância desse acontecimento na minha vida e sorri. Quem não sorriu foi o pessoal daqui de casa que até hoje não faz outra coisa senão me chamar de bobo, otário e etc. $\mathrm{O}$ Miguel está desconfiado. Na opinião secreta dele eu dei o dinheiro para os grevistas da Ítalo-Brasileira (fábrica que está em greve há quarenta dias).

Leônidas chegou dia 13 de julho. Fui posto ao par do caso de L.M.P(1). Me diverti imensamente. A parte que eu tomei nisso tudo foi absolutamente inconsciente, como, aliás, sucede frequentemente comigo.

Para receber o Donda ${ }^{147}$ organizamos um jantar aqui em casa e um “pocker". O jantar não teve nada demais. O "pocker" foi sensacional. Cheguei a ganhar 60 mil réis contra todos. Nunca me aproveitei tanto. Apostava o máximo todas as vezes. O pessoal (Rodolfo, Donda, Lenício, Paulo Af., Emusko) gemia. Depois que me pegaram num blefe de 35\$000 fiquei desmoralizado. Acabei perdendo $21 \$ 000$.

\footnotetext{
${ }^{145} \mathrm{PE}$ refere-se à sua época de ginasiano e ao Sr. Gonçalves, professor de português dos dois correspondentes. O caso é explicitado no artigo "Um discípulo de Oswald em 1935: "No ginásio praticava modernismo sem o saber, até o dia em que vivi um episódio singular. Durante as aulas de química, física ou latim costumava escrever diálogos de teatro, num espírito de gozação e eventualmente em colaboração com meu colega de classe Décio de Almeida Prado. De uma feita não preparara a composição encomendada por Seu Gonçalves, o professor de português. Acuado, aproveitei o intervalo maior de dez minutos para encher uma folha de papel com frases de no máximo três palavras, umas embaixo das outras. Mal entreguei o papel já estava arrependido e temeroso com as eventuais consequências da molecagem. O que me aguardava era o meu primeiro e único triunfo escolar. É preciso lembrar que o ginásio em questão, o Liceu Nacional Rio Branco, havia sido concebido no espírito novo da Reforma da Educação de Fernando Azevedo e Lourenço Filho e que lá por 1931 conservava traços das origens. Imagino que um dos princípios do Liceu era encorajar a originalidade e explico assim o entusiasmo com que foi recebida minha composição por Seu Gonçalves e pelo Diretor, Dr. Almeida Júnior, que a leu nas classes mais adiantadas". (Crítica de cinema no Suplemento Literário, v. 2. Ed. cit., p. 440)

${ }^{146}$ Começa a letra de PE.

${ }^{147}$ Apelido de Leônidas Pacheco Ferreira, que morava no Rio de Janeiro e vinha a São Paulo visitar os amigos do "Cassino".
} 
Eu disse acima que o jantar não teve nada de mais... Teve sim. Convencemos o Coaracy de que eu fazia anos. O Coaracy ficou perturbado.

- O que é a gente se fiar na memória - disse ele - Eu seria capaz de jurar que o Paulo Emílio faz anos em 17 de dezembro. Pensava mesmo que o Chico é que fizesse anos agora por esse tempo. E o engraçado, é que tinha certeza de que havia presenteado e passado telegramas ao Paulo, sempre no fim do ano. Ah! Vá a gente se fiar na História Universal. $^{148}$

Esteve uma pândega.

Descobrimos há dias, entre uma algazarra indescritível que o Paulo Afonso não sabia o que era "verve" e "demagogo". O caso da "verve" foi ótimo. O Paulo Afonso dava conselhos ao Lenício:

- Você Lenício é muito tímido na maneira de falar. Você, um rapaz alto, com um pouco de força que fizesse na voz ficaria fantástico. É preciso falar alto, com entusiasmo. É preciso verve Lenício.

E ao dizer isso o Paulo Afonso fechou os dois punhos, carregou o cenho, abriu a boca num ritual de ódio, lançou os olhos ao céu, e deu guinchos de proletário.

Foi uma correria:

- O que é "verve", Paulo Afonso?

- Paulo Afonso, o que é verve?

- Paulo Afonso não sabe o que é verve!

- Não sabe o que é verve, Paulo Afonso.

Coro! Ah! Ah! Ah! Ah! Ah! Ah! Ah! Ah!

Paulo Afonso, rubro, no meio da sala repetia descontrolado, quente, tonto, desraciocinado, sempre com os punhos cerrados em ar de ameaça parlamentar:

- Verve! Verve! Verve!

Foi um pandemônio. Saltávamos todos em volta do Paulo Afonso, gritando, gargalhando. Eu, Rodolfo, Lenício, Chico, Papai, Mamãe, Emusko e Chicote. ${ }^{149}$ O Miguel num canto também ria mas com medo de que perguntássemos a ele o que era "verve"...

\footnotetext{
${ }^{148}$ Coaracy estava correto, o aniversário de PE era dia 17 de dezembro.

${ }^{149}$ Chicote era o apelido do cachorro da família Sales Gomes, cujo nome era Vercingetorix Codomannus.
} 
Subitamente, Paulo Afonso, alagado em suor, resolveu tomar uma atitude digna: pôs as mãos nos bolso, torceu ligeiramente os lábios deixando os dentes surgirem numa manifestação de presente, e olhou para os lados trêmulo. Os ânimos serenaram e comentou-se o caso o resto da semana.

Quanto ao demagogo, houve uma cena mais ou menos idêntica, mas acrescentada com um episódio curioso - Paulo Afonso com dicionários debaixo do braço, correndo perseguido por todos nós.

Notícias de S. Paulo temos três:

$1^{\text {a) }}$ O fechamento da Aliança.

$2^{a}$ ) As correntes da prosperidade.

$3^{\text {a) }}$ O estouro da boiada.

Não sei se você lê jornais aí. Se não, mande-me pedir informações sobre estas coisas acima. ${ }^{150}$

As cartas que lhe mandei registradas, pelo que vejo não chegaram aí. Creio que por causa do "Abernéssia” que pus no envelope.

Pretendia escrever mais, Fica para amanhã. Ao trabalho!

\section{Paulo Emílio}

(1) atitude do autor diante do materialismo histórico.

Carta datada: "São Paulo, 16- 7- 1935"; autógrafo a tinta azul; papel branco, pautado; 2 folhas (frente e verso); $33 \times 21,8 \mathrm{~cm}$

\footnotetext{
${ }^{150}$ Em 11 de julho de 1935, após quatro meses de existência, a ANL foi fechada por decreto firmado por Getulio Vargas. Alguns dias antes, em 5 de julho, a organização havia promovido manifestações públicas para comemorar o aniversário dos levantes tenentistas e Luis Carlos Prestes havia discursado incitando a revolução. Logo após o fechamento, em 14 de julho, dia das comemorações da Revolução Francesa, a polícia paulistana estava nas ruas para reprimir as manifestações, quando se depararam com um estouro de zebus. As 350 cabeças de bois que vinham de Mato Grosso para serem abatidos em São Paulo, acabaram se dispersando na Estação do Ipiranga. As relações do acontecimento com as manifestações políticas, ligadas ao fechamento da ANL, foram (como no trecho da carta) muito frequentes.
} 
(9) DAP

[Campos do Jordão], 18 de julho de 1935.

Paulo Emílio,

As nossas conversas por carta estão parecendo muito com aquelas que V., Aquiles $^{151}$ e eu travávamos, cada um querendo contar um caso diferente. Tenho a impressão que V. nem leu a última carta minha. Esperava comentários sobre diversos pontos dela (ex: sonho singularíssimo de René Thiollier) mas V. na ânsia de contar casos do Paulo Afonso, me escreve uma carta que não tem absolutamente ligação com o que eu lhe escrevi. Aliás V. sempre foi um péssimo ouvinte. Ainda bem que os casos contados são do Paulo Afonso. E depois, nenhuma crítica às minhas críticas. Se ao menos V. confessasse não ter as lido eu poderia responder, mais ou menos neste estilo:

"Não leste a Paquita e confessa-me tirano!

Pois leu-a e prefaciou-a Alexandre Herculano”.

Mas o seu silêncio nem esse direito de vingança me deixou. A única resposta digna seria eu não tocar nesta carta em suas entrevistas. (Ninguém ainda comparou V. a D. Chiquinha?!)

Vamos porém a elas: em primeiro lugar tenho que agradecer os elogios que o nosso acordo tácito fazia esperar. Porém, V. inimigo declarado de frases feitas, caiu numa que está se formando e que a propósito de Alcântara Machado, ${ }^{152}$ foi muito usada: "um dos espíritos mais interessantes de sua geração".

Estranhei V. incluir, nas duas entrevistas, Lúcia Miguel Pereira ${ }^{153}$ entre a velha geração. Ela tem vinte e poucos anos, começou a escrever com o Boletim de Ariel ${ }^{154}$ há uns três anos e apesar de inteligente, sempre é mulher. Foi gafe, na minha opinião.

\footnotetext{
${ }^{151}$ Refere-se a Aquiles de Barros Fontes, colega do Liceu Nacional Rio Branco e às cartas trocadas entre eles nos tempos de ginásio.

${ }^{152}$ Sobre o escritor e político modernista, Antonio de Alcântara Machado (1901-1935), escreveu Múcio Leão: "E tudo que ele escreveu é escrito num estilo tão pessoal, tão próprio, tão Antônio de Alcântara Machado... Sim, a verdade é que esse escritor subverteu toda a tradicional arte de escrever". (Apud MENEZES, Raimundo de. Dicionário literário brasileiro. Rio de Janeiro: LTC, 1978, p. 390). Alcântara Machado publicou, entre outras obras, Brás, Bexiga e Barra Funda (1927) e Laranja da China (1928).

${ }^{153}$ Lúcia Miguel Pereira (1903-1959), atuando como crítica literária publicou artigos em Boletim de Ariel, Gazeta de Notícias; em Movimento assinou o artigo "A grande sacrificada". Autora de Machado de Assis (Estudo crítico-biográfico), obra publicada em 1936 pela Companhia Editora Nacional.
} 
Achei interessante o anúncio sintético que V. fez dos nossos colaboradores: "Mário de Andrade, o general à força da revolução modernista; Pontes de Miranda, o homem que aplica o que sabe; Lúcia Miguel Pereira, etc.” Tem uma certa semelhança com anúncios de circos: "Poppy, o macaco ensinado que assombrou Viena; Juanito, o homem elástico que engole espada; os Irmãos La Fuentes, etc."155

A generalização que V. fez: "o elemento mais inteligente do Integralismo", é um pouco ingênua. ${ }^{156} \mathrm{E}$ a psicofísica, a metafísica literária, etc. são para espantar o burguês, ou V. está me traindo lendo livrecos sem me contar nada? Nesse caso responderei com uma porção de coisas sobre Oscar Wilde ${ }^{157}$ e então não adianta V. interrogar o Paulo Afonso que nunca saberá onde li isso.

Gostei da piada do Monteiro Lobato e das citações, principalmente a do Monteiro Lobato que é muito fina. ${ }^{158}$ A do Álvares de Azevedo um pouco deslocada. ${ }^{159}$

Gostei, de uma maneira, geral das entrevistas mas achei-as mal escritas.

\footnotetext{
${ }^{154}$ Boletim de Ariel, revista literária editada no Rio de Janeiro entre os anos de 1931 e 1939; um dos periódicos comentados em Movimento na seção destinada a revistas.

${ }^{155}$ Referência à entrevista cedida por PE para o Correio de S. Paulo em 21 de junho de 1935, na qual apregoa: "Assim, em nosso número inaugural, que já está no prelo, temos a colaboração de Mário de Andrade, o general à força da revolução modernista; Flávio de Carvalho, não o artista moderno, mas o conhecedor de arte moderna; Pontes de Miranda, o homem que aplica o que sabe; e Lúcia Miguel Pereira, a inteligentíssima católica, anti-integralista e adepta do socialismo utópico".

${ }^{156}$ Referência à entrevista cedida por PE para o Diário da Noite, Rio de Janeiro, em 29 de junho de 1935, acerca do convite feito a Francisco Luis de Almeida Salles, integralista, para colaborar na revista Movimento. Justifica-se: “Assim para contrabalancear a desconfiança produzida pelo fato da direção de Movimento estar confiada a um membro da Aliança Nacional Libertadora, convidei o acadêmico Almeida Salles, o elemento mais inteligente do Integralismo, para ser nosso colaborador e possivelmente, nosso companheiro de trabalho". Francisco Luiz de Almeida Salles (1912-1996) se tornou um dos grandes amigos de PE. Juntos escreveram sobre cinema na revista Clima e, em 1956, fundaram a Cinemateca Brasileira. Almeida Salles é autor dos livros de crítica cinematográfica: Cinema e verdade (1988) e Estrela da sedução (1990).

${ }^{157}$ Oscar Wilde (1854-1900), escritor irlandês, autor de alguns livros como $O$ retrato de Dorian Gray (1890), Uma mulher sem importância (1893) e Um marido ideal (1895).

${ }^{158}$ Monteiro Lobato (1882-1948), escritor anunciado por PE em duas entrevistas, como um dos possíveis colaboradores de Movimento. Ao Correio de S. Paulo, em 21 de junho de 1935 e ao Diário da Noite, em 29 de junho de 1935, PE afirma, respectivamente: "Precisamos falar ainda com Monteiro Lobato. Acho que ele, para construir conosco não serve. Em todo caso, poderá e com muita eficiência, nos ajudar na destruição. Creio que se sentirá muito à vontade nesse campo"; "Tenho certeza de que não nos negará seu apoio. Ele tem tanto interesse pelas crianças...". Lobato obteve grande reconhecimento no campo cultural por sua literatura infantil, ao criar a série de narrativas ligadas ao Sítio do Picapau Amarelo. PE também tinha adoração pela personagem Jeca Tatu, o qual personificava uma crítica à realidade brasileira da época (Ideias de Jeca Tatu, 1919).

${ }^{159}$ Referência a Álvares de Azevedo, revista dos estudantes da Faculdade de Direito de São Paulo. Na entrevista para o Diário da Noite, PE afirma: "[...] alguns esplêndidos números da Revista Acadêmica, hoje morta, ou pelo menos adormecida. Não falamos aqui na Álvares de Azevedo, porque essa transformou-se em magazine, foi açambarcada por Cerri e etc. Essa ótima associação de meninos de letras precisa reagir." A revista empresta o nome de Álvares de Azevedo (1831-1852), escritor romântico, autor de Noite na taverna (1855) e Lira dos vinte anos (1853).
} 
Achei impagável o seguinte trecho de Jorge Amado ${ }^{160}$ no artigo sobre Lima Barreto:" 161 "que mereciam então de toda a imprensa de elite qualificativos curiosos: assassinos, bêbados, e outras coisas que não se escrevem!" Será cinismo, inconsciência ou blefe? Existe em São Paulo um clube também na várzea chamado: "Machado de Assis Futebol Club". É preciso que Jorge Amado saiba disto.

O L.M.P. é de propósito para que os comentadores da nossa correspondência entendam Lúcia Miguel Pereira?

Depois de escritas estas páginas, fui a Abernéssia e retirei a carta registrada com a entrevista do Correio de S. Paulo, de que V. tinha falado. A demora foi porque os avisos de carta registrada expedidos pelo correio perderam-se entre Abernéssia e Umuarama.

Quanto à questão de ser eu o tal novíssimo, creio que poderia fazer uma conferência sobre Lima Barreto, autor que eu conheço bem. Se é verdade que uma editora vai lançar as suas obras completas como afirma Jorge Amado a ocasião seria oportuna. Mas dificilmente a conferência faria sucesso, na minha opinião, mesmo porque o público desconhece a obra de Lima Barreto. Mas não é só por isso. Há outros motivos que por serem difíceis de expor em carta deixarei para S. Paulo.

Desculpe esse trecho estar um pouco vaidoso. A nossa intimidade creio que se permite a vaidade e mesmo o pedantismo, quando for necessário.

\footnotetext{
${ }^{160}$ Jorge Amado (1912-2001) foi admirado por PE e DAP no campo da militância política. Parceiro de PE na ANL, o escritor baiano vinculou-se ao Partido Comunista Brasileiro. DAP escreveu: "Acontece que a nossa geração - e aqui falo igualmente em meu nome -, por circunstâncias de idade, por ter chegado à vida literária por volta de 1935, passara quase sem transição de Eça de Queiroz e Machado de Assis a Jorge Amado e José Lins do Rego. Os romancistas do sofrido Nordeste é que encarnavam para nós a verdadeira modernidade, ampla, generosa, próxima do povo, ciente de suas responsabilidades sociais [...]". ("Paulo Emílio quando jovem". Seres, coisas, lugares (Do teatro ao futebol). Ed. cit., p. 162). Muitos dos livros de Jorge Amado foram transformados em filmes, vistos por PE, como é o caso de Capitães da areia (1937), Gabriela, cravo e canela (1958) e Dona Flor e seus dois maridos (1966).

${ }^{161}$ Referência ao artigo de Jorge Amado, "Lima Barreto, escritor popular", em A Manhã, do Rio de Janeiro, em 12 de julho de 1935. No início do artigo, se lê: "Está aí uma afirmação [referindo-se ao título do artigo] da qual muita gente duvidará com certeza." Para comprovar sua tese, o autor conta que teria lido em um jornal o anúncio de jogo de time suburbano chamado "Lima Barreto Futebol Clube". Lima Barreto (1881-1922), escritor carioca, buscou denunciar problemas da realidade social brasileira. São de sua autoria, entre outros, os romances Triste fim de Policarpo Quaresma (1911) e Vida e morte de M. J. Gonzaga de Sá(1919).
} 
A pergunta a respeito do êxito da falação e da famosa frase, continua em pé.

Ontem à noite banquei aqui um joguinho de cara e coroa e na brincadeira perdi quase vinte mil réis. O bolso não chegou a ficar vacuolizado, como no seu caso, mas senti-o um pouco rarefeito.

Estão aqui em Umuarama aquelas meninas ousadas que fizeram cordão conosco no Carnaval de 34. Perguntaram pelo Grillo e pelo [Maria Rosa]. São do grupo das Novaes, Cecílias (com e sem queixo), etc... Conhecem até o Aquiles.

A caricatura de Trotski que eu mandei V. deve dar ao Pontes de Miranda. Agradará não só o socialista como o colecionador de cara de coruja.

Tenho lido os jornais e estou ao par do fechamento da Aliança. Li também o número da Manhã em que comenta esse fechamento e estranhei muito ao ver um artigo violento do Álvaro Moreyra. ${ }^{162}$

Segundo uma predição publicada na Noite Ilustrada ${ }^{163}$ do dia 10 o integralismo vai ter um novo chefe. É um rapaz moço, meio calvo que está começando a se pôr em evidência e que despertará fanatismo. Contudo Plínio Salgado não abandonará o credo. $^{164}$

\footnotetext{
${ }^{162}$ Sobre o escritor e jornalista gaúcho radicado no Rio de Janeiro, Álvaro Moreyra (1888-1964), referese o biógrafo de PE, José Inácio de Melo Souza: "A Platéia publicava uma nota dizendo que o 'Quarteirão', reafirmando um dos pontos do seu programa, realizará conferências populares, acabando de convidar vários escritores para esse fim. [...] A nota dizia ainda que no futuro 'Quarteirão' traria Jorge Amado, Álvaro Moreyra, Carlos Lacerda, Pontes de Miranda e Hermes Lima para outras palestras." (Paulo Emílio no Paraíso. Ed. cit., p. 70-1).

163 "Noite Ilustrada", encarte do jornal A Noite, editado no Rio de Janeiro de 1911 a 1957.

${ }^{164}$ Sobre o fundador do Partido Integralista (em 1932), Plínio Salgado (1895-1975), PE escreve em "Euclides da Cunha, Olavo Bilac e o Integralismo", no jornal Vanguarda Estudantil, em setembro de 1934: "Fato interessante é a facilidade com que o chefe nacional integralista se convenceu da adesão de Euclides da Cunha, ou melhor, do busto de Euclides da Cunha às suas idéias. Sinão, vejamos, pouco antes
} 
Um telegrama da Alemanha conta que tendo a juventude nazista tentado atacar a casa de um padre este pediu garantia à polícia. Esta para protegê-lo melhor, diz o telegrama, recolheu-o à cadeia. Achei ótimo o método.

\author{
Já recebi uma corrente. ${ }^{165}$ \\ Lembranças ao Leônidas. Um abraço do Décio
}

Carta datada: "18-7-1935”; autógrafo a tinta preta; papel branco, timbrado: "Pensão Umuarama Campos do Jordão- Retiro, recreação, revigoramento, repouso./ Pensão de $1^{a}$ ordem diária módica. /Não se aceitam pessoas que sofram de moléstias contagiosas. /Gerência Dra. Ethel Stockinger. /Informações em S. Paulo telefone 4-2572./Altitude 1750 metros. Ótimo clima./Estação de Estrada de Ferro, Correio, Telégrafo./ Abernéssia - Campos de Jordão./ Telefone - Abernéssia n. 24”; 7 folhas; 28,5 × 21,5 cm; 2 furos.

\title{
(10) PE
}

São Paulo, 25 de julho 1935.

Querido Décio.

Você não tem razão de se queixar de minha última carta. Eu pretendia lhe escrever muito aquele dia, respondendo a todas suas perguntas e contando também mta coisa interessante, mas tive o que fazer depois do almoço e não pude continuar. Agora, entretanto, tenho tempo. É sábado, oito horas e meia. Já jantei. O Chico, o P. Afonso e o Donda estão lá em baixo mexendo com fichas. Miguel e Lenício devem chegar dentro em pouco.

de descrever a grotesca cerimônia Plinio Salgado afirma que tinha quase certeza de que Euclides da Cunha seria integralista, e logo após clama inspirado: 'Sim, ele seria um dos meus"”.

${ }^{165}$ Refere-se à "corrente da prosperidade". 
Passo primeiramente a comentar sua carta.

No que se refere ao sonho com René, sucedeu um caso gozadíssimo. Eu, qdo leio uma carta pela primeira vez, a minha curiosidade é tanta, que vou pulando palavras. Isso sucedeu também com o que você me escreveu. Tanto que eu quase morri de espanto ao ler o caso do René, pois não tinha percebido que era sonho. Fiquei alarmado e logo com uma súbita simpatia por ele.

Quanto ao caso do P. Af. (que é verídico) aquela minha descrição foi uma experiência - escrever uma coisa afogueada com o espírito absolutamente tranquilo e frio.

As suas críticas, eu as li, sim. Fiquei, até, besta com os seus conhecimentos sobre maleita. Por sinal que verificamos ser aquilo que você disse asneira grossa. O P. Afonso fez questão de corrigir e deixou a história de um jeito bem besta - você desmente o homem e calmamente larga o negócio inacabado. Eu, por mim deixaria aquilo como você escreveu para haver uma certa movimentação (você poderia, como vê, ter evitado aquele [ilegível] para o Flávio) ${ }^{166}$ em torno da revista. Seu Gonçalves ainda não sabe desta.

Não sou conforme você pensa "inimigo declarado de frases feitas". Não tenho absolutamente essa "preocupação", o que redundaria num "preconceito", e desses sim, é que eu sou "naturalmente" inimigo. (Você não anda me achando com uns jeitões do

\footnotetext{
166 O artista plástico fluminense Flávio de Carvalho (1899-1973) colaborou em Movimento, assinando longo ensaio, sofisticado, sobre as novas tendências da pintura contemporânea, resultado, certamente, de sua formação em Universidades europeias, como a Durham, na Inglaterra. Seu artigo na revista revela grande conhecimento da movimentação artística estrangeira: "Examinando o grande número de trabalhos de Arne Hosek (Praga), e mais tarde alguns de Mabel Lapthorn, encontrei que n'estes trabalhos se manifestavam formas cuja significação escapava ao próprio autor, mas que tinha uma significação psicológica profunda e importante. Desse momento em diante começei a acreditar sinceramente no valor da pintura do som, discordando assim dos super-realistas de Paris que absolutamente não acreditam n'essa pintura, contudo conservando uma maior admiração pela pintura super-realista devido ao seu aspecto mais humano" (Movimento, p. 72). Flávio de Carvalho fornece a Movimento entrevistas feitas com Otokar Fisker e Margaret Ludwig. Além da pintura, dedicou-se à escultura, cenografia, engenharia. Publicou, entre outros livros, Experiência n. 2 (1931).
} 
Tristão? ${ }^{167}$ Cá estou com os Estudos na cabeceira). O que eu disse me referindo a você não é mais uma frase, é uma expressão. Você todas vezes que vê um homem que não é gordo, e que bem ao contrário, é o oposto de gordo, você o chama de magro. Eu acho que uma criatura nas suas condições e no nosso meio não pode ser chamado senão de "um dos espíritos mais interessantes dessa geração". E além disso, se você insiste em afirmar que isso é uma frase feita, eu lhe digo que a comodidade e a pendenga encerram a minha inimizade por essas frases...

Quanto ao caso da Lúcia, eu acho que se nós colocamos o Flávio de Carvalho e mesmo o Mário, na "velha" ela pode ir também, se bem que seja "nova", ela não pode é vir para o nosso lado pois nós somos os "novíssimos". Quanto à "gafe" creio que não houve, principalmente pelo fato de eu lhe ter enviado minhas entrevistas... (a seu pedido).

Não fiz, conforme você pensa, generalização alguma ao me referir ao Almeida Sales como o elemento mais inteligente do integralismo. Ao contrário houve particularização tão acentuada que até o isolou. A história tomou o aspecto seguinte. Almeida Sales, um rapaz muito inteligente, que está no integralismo, e etc. Creio que o integralista perdeu a importância que se deslocou para o inteligente. Muita gente pensou que eu disse aquilo com a seguinte intenção. A prova de que nós somos realmente imparciais está no convite que nós fizemos a um elemento, que sendo o mais inteligente do integ., podia até perturbar muitos espíritos. Mas não nos importamos com isso e chamamos, honestamente, esse perigoso inimigo de nossas ideias, para a nossa revista.

Dei muita risada com os seus comentários aos reclames que fiz de nossos colaboradores.

\footnotetext{
${ }^{167}$ Referência a Tristão de Athayde, pseudônimo do crítico literário católico Alceu Amoroso Lima (18931983) e seu livro de crítica literária Estudos - 5 séries (1927-1935).
} 
Quanto aos cursos esquisitos que a nossa revista vai ter, a sua segunda hipótese é parcialmente certa. Trata-se de novos conhecimentos que ando adquirindo, mas não é por meio de livros, mas sim por conversas que tenho mantido com o Flávio e o Oswald. ${ }^{168}$

Pretendo mesmo fazer isso. Mais adiante falarei nisso novamente.

A pilhéria da Álvares de Azevedo você achou deslocada porque sabe que foi encaixada. Fiz um rápido inquérito sobre isso. As cobaias foram P.Af., Chico, Lenício, uns caras vivinhos lá da Escola, etc.

É natural que você ache o que eu escrevo mal escrito e vice-versa. Nós qdo lemos os trabalhos que o outro faz prestamos uma atenção incomum e por isso é que ficamos tão exigentes. Verifiquei isso lendo com uma atenção enorme o Eça e o

\footnotetext{
${ }^{168}$ Sobre a aproximação de PE aos modernistas, DAP escreveu: "Eu acompanhara, é verdade, a primeira de suas [PE] incursões no terreno para nós pouco trilhado do modernismo de 1922 [...]. Cada carta sua anunciava a descoberta de um novo amigo ou conhecido: Oswald de Andrade ('uma ótima criatura', 'não sei dizer ainda se ele é culto ou não') [...] Paulo congregava com seu entusiasmo e o apoio declarado de Oswald de Andrade o que sobrara da Semana de Arte Moderna." ("Paulo Emílio quando jovem". Seres, coisas, lugares (Do teatro ao futebol). Ed. cit., p. 158-9). A relação de PE com Oswald de Andrade merece destaque. Anos mais tarde, em 1964, PE escreveu o ensaio para o "Suplemento Literário" d' $O$ Estado de S. Paulo, "Um discípulo de Oswald em 1935", no qual testemunha: "Éramos mestre e discípulo. O estilo curioso de nossas relações é, como verifiquei mais tarde, bastante frequente. Eu não cessava nunca de agredi-lo. Hoje fico pasmo com a paciência que Oswald de Andrade tinha comigo. Imagino que o divertia" (Crítica de cinema no Suplemento Literário, v. 2. Ed. cit., p. 443). A primeira grande agressão se deu no artigo "O moleque Ricardo e a Aliança Nacional Libertadora", em A Manhã de 21 de setembro de 1935. PE, defendendo o romance de José Lins do Rego, como uma evolução nos romances sociais da época, trouxe à baila Oswald de Andrade e seu livro, de 1934, O homem e o cavalo: "O escritor social deve ser assim. Evoluir com o meio social do qual ele é o representante intelectual no campo da inteligência. Não adianta o escritor dar um grande avanço e tornar-se depois estático, nesse ponto, para o resto da vida. É nisto que deve prestar atenção Oswald de Andrade, que evoluiu muito mais rapidamente do que o meio social que ele quer representar e educar. É preciso, entretanto, deixar-se claro que a evolução do Oswald não se limita às obscenidades inúteis dos seus livros, como pensa muita gente recalcada. Oswald de Andrade é, sem dúvida alguma, um adiantado político artístico, e esse adiantamento que é patente, é todavia, desequilibrado e de um entusiasmo oratório romântico ( $O$ homem e o cavalo). As obscenidades de que falei fazem arte desse desequilíbrio. São motivadas principalmente, segundo creio, pela excitação infantil em que Oswald de Andrade ficou de querer ver a cara que o burguês faria ao ouvir tanto nome feio. O que aconteceu foi que Oswald não conseguiu ver a cara do burguês e nem a do proletário. Este último deu-lhe as costa, recusando levar para casa, onde tem mulher e filhos, um livro obsceno. O primeiro leu o livro escondido, para não se comprometer, gozou as obscenidades e sentiu-se satisfeito. Eis no que deu um livro ( $O$ homem e o cavalo), que poderia ser um estímulo intelectual e político para as massas e que não passou de uma distração picante para o burguês". Nessas duras linhas, PE atacou o "mestre" com coragem e, provavelmente, como ele mesmo afirmou no artigo de 1964, porque "[...] estava convencido de que a principal função do teatro de vanguarda seria a de dar aos operários brasileiros a consciência da alta missão que os esperava. Nesse ponto é que se aguçavam minhas reservas contra $O$ homem e o cavalo". ("Um discípulo de Oswald em 1935". Crítica de cinema no Suplemento Literário, v. 2. Ed. cit., p. 444).
} 
Machado. ${ }^{169}$ Também são fracotes. Causou sensação aqui no "grupo" a sua opinião. Sinto até o P. Af. tentar se escapar das minhas garras mas foi uma reação passageira. Foi só eu apreciar muito uma pilhéria dele e... você logo foi esquecido.

Achei interessante aquele artigo do Jorge Amado. Aquela história das "coisas que não se escrevem" não me chamou a atenção quando li o artigo, ao contrário do que sucedeu a você que ficou todo inquieto. Achei isso interessante e significativo.

Mandei esse recorte para você, lembrando justamente o "Machado de Assis F.C.". Creio entretanto que o fenômeno não é idêntico. Neste caso do "Machado", deve ter sido dada essa denominação por ideia de algum mulato pernóstico que conhecia Machado de nome como um escritor que tinha um ótimo português e que foi mesmo um dos maiores "gênios do nosso vernáculo" segundo o monstrengo da casa de [ilegível]. No caso do Lima Barreto que não era um desmiolado a história muda de aspecto. Nenhum mulato pernóstico conhece o Lima Barreto.

O L.M.P. não foi de propósito. Quanto aos comentadores de nossa correspondência é preciso que deixemos dispositivo sobre isso, a fim de que não seja, por exemplo, o Miguel, o que faria com que nossas cartas perdessem grande interesse, como perderam as do Antonio Torres ${ }^{170}$ com todas aquelas linhas pontilhadas. Principalmente a minha próxima carta a qual creio que não escreverei ela em cuecas, mas nu e com o pinto ereto, pois irei contar coisas alucinantes a você.

A conferência sobre Lima Barreto ficaria formidável principalmente se você se referisse bastante ao ambiente social de subúrbio em que Lima Barreto passou a vida e ao "aspecto de massas" que muitas vezes tem os livros dele. Eu tenho impressão de que Lima Barreto dava uma bruta importância ao povo. Esclarece-me nisso.

\footnotetext{
${ }^{169}$ O escritor Machado de Assis (1839-1908) mostra-se personalidade presente na formação intelectual de PE, citada em três oportunidades nesta correspondência. Cabe assinalar que, em 1967, em parceria com Lygia Fagundes Telles, PE produziu o roteiro Capitu, adaptação cinematográfica do romance Dom Casmurro.

${ }^{170}$ Sacerdote, poeta e polemista mineiro, Antonio Torres (1885-1934) publicou, entre outros livros, Verdades indiscretas (1920) e Prós e contras (1922).
} 
A sua conferência, assim como as outras, se realizará mesmo. A organização cultural de que falei numa das entrevistas é de fato uma realidade. Isso não é devido ao meu esforço. Creio que essa organização surgiria com MOVIMENTO ou sem ele. Tratase de uma espécie de clube de literatos, pintores, escultores, musicistas e etc. Terá uma boa sede com salão para exposições das obras de artistas pobres, fará conferências sobre arte, política, economia, aquelas coisas complicadas todas e etc., além de cursos regulares de uma porção de coisas principalmente literatura. O pessoal que está organizando isso, imediatamente entrou em comunicação comigo por intermédio do Oswald de Andrade. A fusão foi imediata. O Oswald vê em nós, realmente, o primeiro grupo que está aparecendo depois da turma dele, do Mário, etc. Ele quer fazer a ligação entre a geração dele e a nossa. Se interessou muito por você (vê se vai me envergonhar ao chegar aqui, hein!) e pelo romance que penso escrever. Você vai ser um dos fundadores dessa história. Eu vou ser secretário. Essa organização vai congregar toda a intelectualidade de S. Paulo, principalmente a novíssima e a de 1922. Creio que a revista, no meio disso, avançasse com uma bruta facilidade. ${ }^{171}$

Que tal o MOVIMENTO?

Falarei sobre isso qdo tiver recebido carta sua falando sobre a revista.

A Platéia gostou muito da revista. Sentiu que não fosse mais popular. Acrescentou que era menos reacionária e acadêmica que as demais.

A Gazeta achou mto avançada.

O Diário da Noite nos considerou ameaçadores...

As outras notas são simples linhas de elogios banais.

\footnotetext{
${ }^{171}$ Referência ao "Quarteirão", clube de cultura e de arte moderna de São Paulo do qual faziam parte alguns artistas e intelectuais como PE, Oswald de Andrade, Mário de Andrade, Geraldo Ferraz, Anita Malfatti, Guillermo Hohagen, Victor Brecheret, Lasar Segal, Vera Vicente de Azevedo, Flávio de Carvalho, Sérgio Milliet, Raul Vicente de Azevedo, Amador Cisneiros e Alayde Taveiro. Os objetivos da sociedade eram: o desenvolvimento das atividades culturais em São Paulo e a defesa da cultura contra todas as tendências reacionárias nacionais ou estrangeiras; a organização de exposições, reuniões, cursos e debates; o fornecimento de informações sobre cultura e arte à população. PE historia em "Um discípulo de Oswald em 1935": "O clube nunca chegou a se organizar realmente mas foram criadas comissões de todo tipo, menos de cinema, e houve muita reunião." (Crítica de cinema no Suplemento Literário, v. 2. Ed. cit., p. 445).
} 
Espero ainda artigos inteiramente dedicados à revista. ${ }^{172}$

Não escrevo mais hoje. Ainda tenho muita coisa para lhe contar mas estou cansado. Tenho estudado seriamente. A medicina está abandonada.

Agora espero carta sua. Depois disso continuarei. Mande impressões detalhadas sobre MOVIMENTO. Como você sabe me interessarão muito os seus palpites sobre meus artigos. Grande abraço do

\section{Paulo Emílio.}

Décio, não respondi ainda as 2 cartas suas, porque não tenho tido tempo, e assim que arranjar lhe escreverei. Então você ficou sozinho com uma pequena, hein?! Que aconteceu? Flávio faz tempo que não me escreve, não sei o motivo. Bom Décio, até qualquer dia. Um abraço do Miguel. ${ }^{173}$

Carta datada: "S. Paulo - 25 - julho - 1935”; autógrafo a tinta azul; papel branco, timbrado: "MOVIMENTO - revista do presente que enxerga o futuro"; 10 folhas; $28 \times 21 \mathrm{~cm}$.

\section{(11) PE}

São Paulo, 31 de julho de 1935.

Querido Décio,

Vamos ver se dá para eu lhe contar alguma coisa até a hora do almoço.

\footnotetext{
${ }^{172}$ A Platéia, São Paulo, em 25 de julho de 1935, noticia: “O primeiro número de Movimento, a anunciada 'revista do presente que enxerga o futuro' foi lançada ontem à publicidade [...]. Uma publicação que sem ser, infelizmente, muito popular, é bem menos reacionária e acadêmica que as demais do gênero." A nota d'A Gazeta, São Paulo, em 25 de julho de 1935, informa: "É uma revista moderna, avançada que trará contribuição valiosa para o nosso movimento cultural". O Diário da Noite, São Paulo, em 22 de julho de 1935, adverte: "Esse movimento de defesa é uma atitude ameaçadora de ataque".

${ }^{173}$ Abaixo da assinatura de PE, há um bilhete de Miguel Ferreira da Silva Neto a DAP.
} 
Continuam os noticiários dos jornais a tratar de MOVIMENTO. O Diário de $S$. Paulo de ontem publicou essa nota que lhe mando. Você sabe quem é esse G?

Súmula traz no seu número de agosto um artigo de uma página em que se refere particularmente à "Interpretação materialista", à "Posição do artista", e a "Trecho de vida"174 de Hag Reindrahr, judeuzinho interessante, meio parecido com você, que tem uma admiração fanática por Pandiá Calógeras e Michael Gold... ${ }^{175}$ Acho que você vai gostar desse rapaz. Ainda não quis trazê-lo aqui antes de você chegar. ${ }^{176}$

A Folha da Noite na seção “À Margem dos Fatos” a propósito de um empréstimo que o Banco do Brasil vai conceder ao Rio Gde do Sul cita trechos da "Interpretação" e acaba aconselhando a leitura desse estudo a todos. ${ }^{177}$

O Mozart Firmeza deverá publicar por esses dias uma notícia-crítica no Correio de S. Paulo e o Geraldo Ferraz, secretário do Diário da Noite me prometeu também um longo comentário sobre MOVIMENTO. ${ }^{178}$

O Correio Paulistano e o Estado publicaram notas que perdi. Vou tratar disso hoje. $^{179}$

O Túlio numa entrevista concedida ao Correio parece que fala de MOVIMENTO. Vou ver isso.

174 O Diário de S. Paulo, de 30 de julho de 1935, traz matéria assinada por "G.", elogiando Movimento “Trata-se de uma revista moderna dirigida e colaborada por gente de hoje 'que enxerga o futuro' [...] é órgão dos moços de hoje que enxergam o futuro. E para dar disso prova concreta, o número de julho corresponde, também, aos meses de agosto e setembro vindouros. Já é enxergar...”. Em Súmula, de agosto de 1935, revista de esquerda criada em São Paulo por Amador Cisneiros, apresenta artigo longo sobre os textos mais importantes de Movimento. Cisneiros era proprietário do Centro de Expansão do Livro e da Imprensa, responsável pela distribuição de Movimento.

${ }^{175}$ A referência ao político e historiador carioca João Pandiá Calógeras (1870-1934) e ao escritor norte americano Michael Gold (1864-1967), autor de Judeus sem dinheiro (1930), livro que exerceu influência sobre autores brasileiros como Jorge Amado, Graciliano Ramos e José Lins do Rego.

${ }^{176}$ Hag Reindrahr, um dos pseudônimos criados por PE em Movimento e o que mais foi utilizado por ele ao longo do tempo. O "judeuzinho interessante", autor do poema "Trecho de vida", dedicado aos "companheiros de prosa de mictório da fábrica" é, segundo DAP, "uma espécie de Rimbaud da Revolução, pela precocidade. Falecido aos dezoito anos (assim ninguém se lembraria de cobrar a sua presença), reunia condições para ser o pária ideal: judeu, operário, filho de prostituta, de nome exoticamente não nacional. [...] Ele [PE] se divertia como um menino quando alguém - e foram muitos acreditavam no seu herói mítico, em cuja existência ele tentara me enredar na correspondência de Campos do Jordão, sabendo perfeitamente que fracassaria." ("Paulo Emílio quando jovem". Seres, coisas, lugares (Do teatro ao futebol). Ed. cit., p.163-4).

${ }^{177}$ O artigo da Folha da Noite, São Paulo, em 29 de julho de 1935, termina com a seguinte sugestão "É preciso, porém, ler o interessante estudo de princípio a fim. O materialismo histórico explica, sem dúvida, e explica satisfatoriamente, certas particularidades que à política de colaboração convém fazer esquecer".

${ }^{178}$ Geraldo Ferraz, no Diário da Noite, São Paulo, de 3 de agosto de 1935, publica o "longo comentário", prometido no qual avalia: "Tipograficamente há certas incertezas na distribuição da revista. Seria necessário também maior número de colaborações e seções fixas para não ficar misturado noticiário e literatura. Há muita dispersão de esforços, mas se a direção coordenar melhor a matéria pode-se esperar uma boa revista".

${ }^{179}$ As notas são de 23 de julho de 1935 no Correio de S. Paulo e a de 25 do mesmo mês, no Estado de S. Paulo, apenas apresentando a organização da revista, com suas seções e endereço. 
O ambiente está mto favorável. Conforme esperávamos a "Interpretação materialista" está provocando grande curiosidade.

Ando mto feliz. Morreu o Pedro de Toledo ${ }^{180}$ e o Mário de Andrade está chateadíssimo com o Rodrigues Alves. Segundo o Donda só falta a Faculdade de Direito cair, para eu me sentir num Paraíso.

O Young vai ler o "Manifesto" $5^{\mathrm{a}}$ feira na Álvares de Azevedo. ${ }^{181}$

O Álvaro detestou a revista. Fui averiguar bem e descobri que ele só tinha lido a nota do Miguel sobre o livro de Essad Bey. ${ }^{182}$ Para me vingar pedi a ele, muito interessado, uma longa crítica metendo o pau na revista, para o segundo número. $\mathrm{O}$ Álvaro, muito perturbado, disse que ia tratar disso.

O Coaracy disse ao Paulo Afonso que a revista estava péssima. O Paulo Afonso fez uma cara sentida e o Coaracy achou a revista boasinha.

Aquele F.M.A. do Diário achou, me disse o Cyro, ${ }^{183}$ as críticas de livros novos uma droga. Vou averiguar isso.

\footnotetext{
${ }^{180}$ A inimizade de PE com o grupo do qual o advogado e político Pedro de Toledo (1860-1935) fazia parte é evidente no trecho a seguir, retirado da entrevista concedida ao Diário da Noite, em 13 de maio de 1935: "Os centros acadêmicos encabeçam movimentos de antipatia coletiva de uma escola contra a outra, como já tem acontecido com a Faculdade de Medicina em relação à Faculdade de Direito. E mesmo que isso não sucedesse, o seu trabalho no sentido de movimentação de massas de estudantes, não seria suficiente, a não ser que se tratasse de uma homenagem ao Dr. Pedro de Toledo ou da transladação de pedaços de muro da velha Faculdade de Direito...” Pedro de Toledo foi, em 1932, nomeado por Getulio Vargas interventor federal do governo do Estado de São Paulo.

181 "Manifesto", escrito por PE para apresentar Movimento, texto foi lido na "redação" de Álvares de Azevedo.

${ }^{182}$ Menção a Álvaro Moreyra e à resenha para Movimento, assinada por Miguel Ferreira da Silva Neto, focalizando o livro A luta pelo petróleo, 1935, de Essad Bey, "pseudônimo de um dos magnatas do petróleo e notável escritor moderno." (Movimento, p. 103). O livro contou com prefácio de Monteiro Lobato.

${ }^{183}$ Referência ao Diário da Manhã, de Curitiba, onde trabalhava Cyro Sans Duro, amigo de PE. Movimento estampa seção dedicada às resenhas de livros novos.
} 
Vou almoçar. Amanhã vai mais coisa.

Abraço do

\section{Paulo Emílio}

Carta datada: "S. Paulo - 31 - julho - 1935"; autógrafo a tinta azul; papel branco, pautado; 3 folhas; $26,7 \times 20,5 \mathrm{~cm}$.

\section{(12) DAP}

[Campos do Jordão], $1^{\text {o }}$ de agosto de 1935.

Paulo Emílio

Só terça-feira recebi a sua carta e é esse o motivo porque não lhe escrevi antes. Primeiro vão as impressões sobre Movimento e se a carta ameaçar ficar muito comprida, como é provável deixarei o resto para outra, seguindo, aliás, o seu método ("pretendia escrever muito mais", etc).

Darei primeiramente impressões particulares e depois a impressão geral.

Capa: boa. Não desista V. do desenho que os seus já estão quase iguais ao da Anita. ${ }^{184}$

Manifesto - V. talvez se lembre que eu queria fazer uma apresentação. Aí vai ela um pouco parecida no estilo com os da Lúcia. ${ }^{185}$ No entanto é uma resposta ao dela.

\footnotetext{
${ }^{184}$ A ilustração da capa do primeiro número de Movimento traz a assinatura de Anita Malfatti (18961964), artista plástica formada na Alemanha e nos Estados Unidos, precursora do movimento modernista brasileiro. Mário de Andrade avaliou: "Não posso falar pelos meus companheiros de então, mas eu, pessoalmente, devo a relação do novo e a convicção da revolta a ela e à força de seus quadros [...]. Foi ela, foram os seus quadros, que nos deram uma primeira consciência da revolta e de coletividade em luta pela modernização das artes brasileiras. Pelo menos para mim”. (Apud ROBERTO, Pontual. Dicionário de artes plásticas no Brasil. Rio de Janeiro: Civilização Brasileira, 1969, p. 332). PE havia remetido a DAP esboços de desenhos de sua própria autoria, utilizando formas geométricas, em diálogo com a estampa de Anita Malfatti.

${ }^{185}$ DAP compara o seu escrito, em anexo à carta, ao artigo "A grande sacrificada" de Lúcia Miguel Pereira, estampado na revista. O primeiro texto de Movimento é um manifesto (não assinado) de PE, em que ele fornece a intenção da revista e de seus participantes. Nele se lê: "A mocidade do Brasil atual tem uma função determinada pela História. A geração que nos antecedeu recua, apodrecendo. Nós precisamos avançar e ocupar os postos para os quais estamos sendo chamados por uma necessidade social de novas energias, novas concepções, novo sangue, nova moral...” (Movimento, p. 3)
} 
A minha apresentação seria, penso, mais prudente, menos arrebatada, melhor para os espíritos burgueses que a sua, não deixando de ter ao mesmo tempo um tom avançado. A sua tem a vantagem, importante no Movimento, de ser mais agitada, menos prudente (não sei se V. me compreende) parecendo, mais que o meu, artigo de moço. Porque talvez eu não seja mais velho que V. mas sou seguramente mais antigo. Pelo o que eu disse creio que V. compreenderá as vantagens e os defeitos, intimamente ligados, que vejo em seu "Manifesto". Como artigo pessoal a minha apresentação está melhor, como "Manifesto" o seu está melhor. Todo esse trecho está meio confuso mas a bom entendedor...

Acho que $\mathrm{V}$. deve publicar a minha apresentação no lugar do manifesto, em primeiro lugar, mas já como artigo e assinado.

Não gostei absolutamente (talvez já espere isso) do tal entrechoque e batalha. ${ }^{186}$

Não consegui entender o artigo do P. de Miranda na primeira e única tentativa que fiz nesse sentido. O pouco que entendi, gostei. Pouca gente o lerá. ${ }^{187}$

"A interpretação materialista" "188 muito interessante e creio que fará sucesso escandaloso. Mande-a ao Mário Pinto Serva ${ }^{189}$ e outros entendidos. O pessoal todo vai ficar muito admirado.

Uma coisa. O artigo diz:

“Os Paulistas contaram com uma enorme benevolência do Interventor: conseguiram uma grande quantidade de armamentos com que os Estados Unidos queriam fortalecer as posições de seu testa-de-ferro", etc. Essa notícia, certa (era para vir até um vapor, que chegou atrasado), não contradiz o resto do artigo segundo o qual os Estados- Unidos era a favor da ditadura e Londres estava conosco?

Outra coisa:

\footnotetext{
${ }^{186}$ PE encerra o "Manifesto" afirmando que "MOVIMENTO é o entrechoque de filosofias, é a batalha de concepções".

187 "Filosofia clássica e filosofia científica" de Pontes de Miranda, primeiro artigo da revista e o mais longo (página 5-21), discute a relação entre a filosofia antiga (clássica) e a moderna (científica).

188 Referência ao artigo, sem assinatura, "Interpretação materialista da revolução de São Paulo" (Movimento, p. 22- 37); sob o título vem a indicação da seção: Sociologia. Em nota de rodapé, encontrase a explicação editorial: "Este curioso ensaio foi traduzido do espanhol. O Original não traz discriminação do nome do autor." Em cartas posteriores fica evidente que a tradução foi realizada por PE e que o autor é Labirse.

${ }^{189}$ Mario Pinto Serva (1881-1962), jornalista, era conhecido como ferrenho adversário dos modernistas. Sobre ele afirma a ensaísta Maria Eugenia Boaventura: "Possivelmente os textos publicados na Folha da Noite [contra os modernistas] foram escritos por Mário Pinto Serva, um dos seus jornalistas mais atuantes e crítico feroz da semana." (BOAVENTURA, Maria Eugenia."Chuva de batatas". 22 por 22: a semana de arte moderna vista por seus contemporâneos. São Paulo: Edusp, 2010, p. 24-5).
} 
a plantação de algodão daqui faz bastante concorrência a dos Estados Unidos. Será que há interesses britânicos, traduzidos por algum empréstimo, no dinheiro que facilitou o surto algodoeiro?

A tradução boa.

Gostei muito do artigo da Lúcia apesar de desmenti-lo na "apresentação". 190

A notícia da Semana da Educação está interessante. ${ }^{191}$ Compreendo perfeitamente a sua "real alegria" ao ver falar em pênis perto de senhoras. É a mesma salutar alegria (sadismo segundo o Chico) ${ }^{192}$ que V. sente ao falar em pinto, etc, perto da Maria ${ }^{193}$ ou então junto a primas desprevenidas. Achei graça nas severas reprimendas às manifestações ginasianas.

O artigo do Mário de Andrade muito bom. Eu não tinha visto no livro nada do que ele enxergou. Estou quase relendo - o que aumentou o meu interesse por ele. ${ }^{194}$

"O Rabo e o Homem", 195 regular. As vantagens do rabo geralmente forçadas. Há partes engraçadas pela novidade e esquisitice da ideia. A impressão que me ficou é que ele descreve o rabo sempre pensando num rabo de macaco, peludo. Ora nosso rabo seria como nossa pele, branco, quase sem pelos, principalmente nas mulheres, horrível em suma! Imagine a tal moça do "footing" com um rabo assim. Seria uma coisa medonha, lembraria barata descascada.

\footnotetext{
${ }^{190} \mathrm{O}$ artigo de Lúcia Miguel Pereira, "A grande sacrificada", é um alerta à mocidade sobre os problemas das influências de gerações: "Uma geração não pode absorver a outra, nem mesmo para lhe poupar sofrimentos" (Movimento, p. 38).

191 “A semana da educação sexual em São Paulo", assinado por H.H., outro pseudônimo de PE na revista. Sobre os pseudônimos criados por PE em Movimento, DAP relatou: “[...] Quanto aos novíssimos, surpreendiam pela quantidade e variedade: Hag Reindrahr (poesia), no sumário aparecendo como Hag Harnhestein, Ray Barbosa (noticiário de teatro), Joaquim Mauriti (crítica teatral), Pera Neto (noticiário de arte), Isac Blion Martins (crítica de revistas). É que PE, achando provavelmente patusca (palavra de sua predileção) uma revista redigida quase do princípio ao fim por uma só pessoa, não podendo realizar o grande milagre da multiplicação de escritores jovens, realizara o pequeno milagre da multiplicação de pseudônimos seus. Uns teriam vida efêmera, produtos de um capricho momentâneo. Pêra Neto, por exemplo, era uma alusão fugaz a Pero Neto, poeta da Faculdade de Direito, e Ray Barbosa nascera apenas para ser, por um dia, neto natural de Ruy Barbosa. Hag Reindrahr [...] ao contrário, estava fadado a possuir uma existência literária um pouco mais longa, ameaçando transformar-se num verdadeiro heterônimo". ("Paulo Emílio quando jovem". Seres, coisas, lugares (Do teatro ao futebol). Ed. cit., p. 157-8).

${ }^{192}$ Francisco Guilherme Sales Gomes, único irmão de PE, mais conhecido por Chico e apelidado de Eme por PE. Os dois, nesse período, eram amigos e próximos, mas Chico muito tímido, diferentemente de PE. Foi engenheiro químico, enriquecendo-se com investimentos na bolsa de valores. PE passou longas temporadas na sua fazenda em Casa Branca.

${ }^{193}$ Empregada doméstica da família Sales Gomes.

${ }^{194}$ Referência ao artigo "Roberto" de Mário de Andrade, em Movimento, focalizando romance de Sérgio Milliet, Roberto de 1935.

${ }^{195}$ O artigo "O homem e o rabo" apresenta a indicação: "(Short fisiológico). De Diabo, novela a sair de Luiz Navarro Filho".
} 
Versos - não gostei de nenhum. O melhorzinho é o da fábrica. ${ }^{196}$

O seu artigo muito bom e necessário mesmo. ${ }^{197}$ Além do mais está bem escrito, de fácil leitura. Só não compreendi o seguinte trecho:

"E isso porque, o estremecimento social sofrido pelo Brasil em 1930, foi especialmente forte no Estado de São Paulo, por ser esse líder econômico, e, portanto, político do país. Este súbito e transitório deslocamento, unicamente político, sem articulação na realidade econômica", etc. Qual deslocamento é esse que V. não especifica qual é?

A propósito, a primeira frase do artigo do P. de Miranda está truncada? ${ }^{198}$

Ao contrário do que esperava achei entendível o artigo do Fernando [sic] de Carvalho e bastante interessante para quem, como eu, não tinha noção sobre o assunto pintura moderna. Tenho cá umas dúvidas que depois formularei e quero que Flávio de Carvalho me esclareça. ${ }^{199}$

$\mathrm{O}$ artigo do Quinquim ${ }^{200}$ bastante fraco e exagerado. Aliás, nele o seu burguesismo fez V. cair numa bela contradição. Você, como bom comunista, escreveu:

\footnotetext{
${ }^{196}$ Menção ao poema "Trecho de vida", assinado por Hag Reindrahr, pseudônimo de PE. O poema, composto por rimas simples e versos que oscilam entre o cômico e o trágico, é dedicado aos "companheiros de prosa do mictório da fábrica" e delineia a figura de um operário tuberculoso servindo, segundo DAP, para "caçoar levemente de coisas sagradas". A ironia está na ingenuidade da situação apresentada (um operário tuberculoso que perde o emprego por mandar o "gerente para aquele lugar") e resulta em crítica aos argumentos de um comunismo ortodoxo, frequente naquele período. A criação de Hag, o operário tuberculoso e injustiçado, pode ser encarada ainda como autocrítica, se lembrarmos que PE era herdeiro de uma família burguesa, proprietária de uma indústria de tecido. Esse questionamento de classe é evidente na entrevista para A Platéia, em 6 de novembro de 1935, em que PE alude a Hag Reindrahr, como o "operário judeu que morreu de tuberculose aos 18 anos" em decorrência das péssimas condições de trabalho da fábrica dos Sales Gomes.

${ }^{197} \mathrm{O}$ artigo "Considerações sobre o artista revolucionário na sociedade burguesa (a propósito da morte de Facio Hebequer)" é como "Trecho de vida", questionamento (nesse caso, sem nenhuma ironia) de conceitos rígidos usados pela esquerda brasileira. Aqui, Paulo Emílio avalia as posições do artista, do intelectual, da burguesia na sociedade e apresenta sua posição em face das relações entre arte e revolução. $\mathrm{O}$ autor afirma que "a arte política tem grande valor como incentivo à revolta" e faz dura crítica à ideia de que o artista revolucionário não deve ter contato com a burguesia, ou vender suas obras para a burguesia. Ele explica: "É um absurdo, porque se generalizarmos essa atitude crítica para o proletariado deveríamos também achar esquisito que um revolucionário fizesse sapatos ou tecidos para a burguesia. É um caso absolutamente idêntico" (Movimento, p. 65). No artigo, PE explica que havia formulado o pensamento expresso no texto ao saber da morte do artista uruguaio, radicado na Argentina, Guillermo Facio Hebequer (1889-1935). PE conheceu quadros da produção plástica socialista de Hebequer, como a série de litografias Tu historia compañero.

${ }^{198} \mathrm{Na}$ abertura do texto de Pontes de Miranda se lê: "A atitude mental do homem, quando sabia pouco, não pode ser a mesma que assumiu, quando soube que o saber que encheria a vida, menos ainda a dessoutro tempo em que o só conhecimento da Física do átomo excede, de-regra, a capacidade de assimilação dos homens" (Movimento, p. 5).

${ }^{199}$ Menção ao artigo "As novas tendências da pintura contemporânea", de Flávio de Carvalho, quem para PE era "não o artista moderno, mas o conhecedor da arte moderna". (Correio de S. Paulo, 21 de junho de 1935).

200 Artigo "Sexo de Renato Viana" assinado por Quinquim, apelido de Joaquim Mauriti, outro pseudônimo de PE em Movimento.
} 
"Porque a arte deve pertencer à grande massa popular. Deve ser feita para dar alegria a essa massa e por isso deve ser, por ela, compreendida e amada". Se V. diz isso da arte em geral, com muito mais razão deve dizer do teatro. No entanto V. elogia, sem restrições nesse sentido, o teatro de Renato Viana, que é teatro de tese, freudiano, antipopular, feito para as elites que aguentam uma peça monótona, dialogada, porque acham interessante a tese. ${ }^{201}$

Reparei nisso ao ler o artigo "A crise do teatro e sua causa" (Rev. Contemp. $\left.n^{o} 1\right)$ onde se lê o seguinte, referindo ao teatro da Rússia: "A arte retoma a sua verdadeira função social e popular. Ela não mais pertence a uma elite 'blasée', fatigada e crítica”. E pouco adiante: "Sábia advertência ao teatro preconceituoso do Sr. Renato Viana..."

Aliás, essa revista diz que o tal Deus de R. Viana é "um dramalhão clerical absurdo, incoerente".

Você erra também quando diz: "Porque teatro escola é teatro". Pelo que li, Sexo pode ser um bom espetáculo, interessante e inteligente, mas não é teatro onde o principal é ação. Se houver tese, a ação é que deve demonstrá-la sem auxílio dum sujeito (nesse caso Dr. Calazans) muito inteligente, que explica tudo ao público. Qual Paulo, isso de teatro é cá conosco... V. confunde literatura e teatro.

"Arte soviética": cacete. "Exposição de pintura e escultura", por exemplo é uma simples notinha sem nada que interesse a nós. ${ }^{202}$

Entrevistas muito cacetes dando a impressão que é para encher papel. ${ }^{203}$

Livros novos ${ }^{204}$ têm ao menos a grande vantagem de não ser, como usualmente, elogios inexpressivos. Há nele alguma coisa que não gosto mas para comentar crítica por crítica precisaria um tempo enorme. Prefiro fazer oralmente quando estiver aí.

\footnotetext{
${ }^{201}$ Renato Viana (1894-1953) autor, diretor, ator. Durante dois anos, lutou pela criação do Teatro-Escola e em 1934 conseguiu fundá-lo. A proposta era formar uma companhia modelo à qual se vincularia um curso de teatro. Muito polêmica foi a estreia da peça Sexo que, segundo o artigo de Quinquim, "é um excelente espetáculo de pensamento, de cultura, de linguagem elevada, diálogos cheios de vivacidade e elegância". Para o crítico, "aos episódios dramáticos são habilmente intercaladas algumas cenas nas quais aparece um divertido boêmio que tem uma concepção original sobre os homens e a vida, mantendo o bom humor da plateia". Renato Viana foi autor e diretor de diversos roteiros teatrais, entre eles: A última encarnação de Fausto (1922); O homem silencioso dos olhos de vidro (1932); Sexo e Deus (1934). Além do Teatro-Escola foi o fundador da Escola Dramática do Rio Grande do Sul, do Teatro Anchieta (1940) e do Teatro do Povo (1946). Em 1948, foi convidado a dirigir a Escola de Teatro Martins Pena.

${ }^{202}$ Movimento traz um pequeno artigo "Arte Soviética" assinado por outro pseudônimo de PE, Pera Neto, que resume os acontecimentos artísticos soviéticos e é dividido em tópicos: "Ópera e teatro", "Exposição de cerâmica", "Exposição de pintura e escultura" e "Exposição infantil de arte".

${ }^{203}$ As três entrevistas de Movimento são com a declamadora Berta Singerman, com Otokar Fisker, reitor da Universidade Carlos IV de Praga, e com Margaret Ludwig, sobre a música moderna inglesa.

${ }^{204}$ A penúltima seção da revista Livros novos é reservada para resenhas de 15 livros de diversos assuntos, assinadas por diferentes autores, sendo que oito são de PE e duas de DAP.
} 
"Livros de Mário de Andrade" maldoso sem necessidade. ${ }^{205}$ Além disso é injustiça negar conhecimentos sobre A. de Azevedo a Vicente de Azevedo, que é literato somente porque Álvares de Azevedo existiu. Toda a sua produção é sobre isso.

Revistas - bom sem muita novidade. ${ }^{206}$ A da Novela está bom (mande-me ela em segredo). Não gosto nada dos formidáveis a respeito da Revista Contemporânea. É uma palavra tão barateada e tão vulgar! Parece artigo desses rapazes que acham que o maior modernismo e o maior chic é usar palavras exageradas (formidável!; fantástico!; do outro mundo, etc...).

Revisão boa, bem melhor que eu esperava.

Curioso é os artigos que deviam ser da redação (assim: "Conferências de Movimento", "Livros de Mário de Andrade", "Segunda edição de um romance de V. Cy", 207 “Teatro-Escola de São Paulo", "Vida do operário em São Paulo", etc) trazerem grotescamente umas iniciais ou uns nomes embaixo.

Não creio que Movimento fará sucesso, a não ser escandaloso. Que interesse o público só a "Interpretação", o artigo da Lúcia, "O homem e o rabo" e talvez o seu artigo. "Roberto" só para quem o leu. "Filosofia clássica e científica" só para quem conhece o assunto. "Pintura moderna" de F. de Carvalho não interessa o público.

Nesse prisma o Movimento está bem fraco. Por que não tem colaboração de Gilberto Amado, M. de Medeiros e Almeida Sales, que já estavam prometidos? ? $^{208}$

Você deve mandar fazer um carimbo assim:

Vide pág...

que é de muita utilidade. Eu quero mandar o Movimento para muitas pessoas especialmente pela "Interpretação", e esse carimbo destaca o motivo pelo qual mandamos a revista.

\footnotetext{
${ }^{205}$ A última resenha da seção, "Livros de Mário de Andrade", assinada por PE, refere-se a uma edição da Revista Acadêmica que sairia em breve contendo dois ensaios críticos de Mário de Andrade $(O$ Aleijadinho e Álvares de Azevedo). Na resenha, lê-se: "[...] dada a agudeza de observação crítica de Mário de Andrade, qualidades que infelizmente faltam a outros autores de estudos sobre Álvares de Azevedo, como por exemplo Veiga Miranda e Vicente de Azevedo a quem, se sobram esforços e boa vontade, faltam conhecimentos e... 'jeito'...'(Movimento, p. 107)

${ }^{206}$ Revistas é a última seção, assinada por Isac Blion Martins (ou seja, PE) e tem comentários sobre nove revistas da época.

${ }^{207} \mathrm{O}$ texto "Segunda edição de um romance de V.CY" é um comentário do romance Frida Mayer de Vivaldo Coaracy (1882-1967), escritor e colaborador de $O$ Estado de S. Paulo.

${ }^{208}$ Gilberto Amado (1887-1969), Mauricio de Medeiros (1885-1966) e Francisco Luis de Almeida Salles. Os três escritores participariam do segundo número de Movimento. Gilberto Amado, correspondente carioca foi membro da Academia Brasileira de Letras e autor, entre outras obras, do romance $O s$ interesses da Companhia, de 1942. O médico e jornalista Mauricio de Medeiros se tornou conhecidos pela crítica ferrenha aos rumos tomados pela Revolução de 1930, no Diário Carioca e no jornal paulista A Gazeta.
} 
Vou parar que já estou bambo de escrever. A pena é péssima, o tinteiro não tem quase tinta, e a minha mão não tem bastante mobilidade por causa do frio. São as razões da letra horrível.

O resto fica para outra.

Lembranças ao pessoal e você receba um abraço do

Décio

A minha apresentação ainda sofrerá mudanças. O que vai é só para dar uma ideia. Talvez (se der jeito) vá junto com esta uns desenhos da cigarra. ${ }^{209}$

A propósito do Movimento.

O nome da nossa revista Movimento parece estar na moda atualmente. Mal o tínhamos escolhido e surgiram de todos os lados informantes bem intencionados que nos certificaram da existência de vários Movimentos. No Rio havia um, já falecido. Em Recife outro, vivo ainda. Na França, nos informou alguém, há também um Mouvement. E por fim soubemos da existência de um Movimento no Rio, ${ }^{210}$ novo como o nosso, que ia aparecer editado pelo Clube de Cultura Moderna. Tudo isso é resultado, me parece, de um dos caracteres mais significativos da nossa época: a consciência que temos de que estamos em movimento, de que a nossa época é de transição, fato assinalado há já algum tempo. Não é outra, aliás, a explicação da escolha desse título.

Outro fato de interesse, ao meu ver, foi o acolhimento que a nossa ideia teve entre a velha geração. ${ }^{211}$ Ninguém se negou a colaborar conosco e as respostas que tivemos aos nossos pedidos de ajuda podem ser sintetizadas na resposta que nos deu Miguel Osório de Almeida: ${ }^{212}$ "Eu não gosto de dizer não aos moços”. Essa resposta, em sua simplicidade, mostra bem, entretanto, a confiança que a geração passada

\footnotetext{
${ }^{209}$ Desenhos não localizados pela pesquisa.

${ }^{210}$ Cyro Sans Duro comenta a "interessante coincidência" em seu artigo "Movimento", publicado no Diário da Manhã, de Curitiba, em 10 de agosto de 1935: “O nome desta revista não é estranho para quem acompanha o desenvolvimento e a evolução da indústria livresca. Há também o Movimento, órgão do Club de Cultura Moderna, do Rio de Janeiro".

${ }^{211}$ A velha geração a que se refere é a dos modernistas. A intenção mostra-se clara no seguinte trecho do "Manifesto" da revista: "Nesse nosso empreendimento temos o apoio intelectual e material de elementos de outra geração que se puseram ao nosso lado". (Movimento, p. 3).

${ }^{212}$ Miguel Osório de Almeida (1890-1952), médico, fisiologista, cientista e professor estreou nas letras em 1925, com seu volume de ensaios Homens e coisas de ciência.
} 
deposita na mocidade. Por toda a parte, a geração "avant-guerre" reconhece que falhou, que não pode resolver nenhum dos problemas que afligem o mundo e dentro do seu ceticismo acredita, entretanto, nas novas gerações. Ainda no primeiro número do Movimento, Mário de Andrade, tratando de sua geração, alude a "essa horrenda, tiraníssima, martirizante incapacidade de ser socialmente" que os torna incapazes de compreender e defender os novos credos, como o comunismo e o fascismo. ${ }^{213}$ Ao mesmo tempo, e é essa a tragédia, falta-lhes a convicção necessária para sustentar a liberal-democracia. Descrêem ou não acreditam suficientemente na liberal-democracia e ao mesmo tempo não podem aceitar plenamente nem o comunismo, nem o fascismo, as novas tendências políticas. Daí os chamados "simpatizantes", forma incolor, por enquanto mais ou menos neutros.

Em tal situação nada havia senão apelar para a mocidade. E esta, otimista, confiante em si mesma, com outra mentalidade e outras diretrizes, aceitou plenamente essa missão. Nunca, como agora, a mocidade se interessou tanto pela política e pela sociologia e a força dos partidos que pretendem realizar a mutação por todo presente está justamente na juventude.

Em todo o mundo a mocidade estuda, discute, afirma, combate. Entre nós só depois de 1930 é que apareceu esse fenômeno, tendendo cada vez a se acentuar mais. A mocidade brasileira já se movimenta, já estuda, já produz. Movimento é uma das consequências disso e daí acreditarmos no seu êxito. Esperamos que a nossa geração saiba corresponder à confiança da geração passada.

Carta datada: "1-8-935”; manuscrito a tinta preta; papel branco, manchas por oxidação, timbrado: "Pensão Umuarama - Campos do Jordão-Retiro, recreação, revigoramento, repouso./ Pensão de $1^{a}$ ordem diária módica. /Não se aceitam pessoas que sofram de moléstias contagiosas. /Gerência Dra. Ethel Stockinger. /Informações em S. Paulo telefone 4-2572./Altitude 1750 metros. Ótimo clima./Estação de Estrada de Ferro, Correio, Telégrafo./ Abernéssia - Campos de Jordão./ Telefone - Abernéssia $n$. 24 "; 9 folhas; $28,5 \times 21,5 \mathrm{~cm} ; 2$ furos.

Anexo: manuscrito a tinta preta; papel branco, manchas por oxidação, timbrado: "Pensão UmuaramaCampos do Jordão- Retiro, recreação, revigoramento, repouso./ Pensão de $1^{a}$ ordem diária módica. /Não se aceitam pessoas que sofram de moléstias contagiosas. /Gerência Dra. Ethel Stockinger. /Informações em S. Paulo telefone 4-2572./Altitude 1750 metros. Ótimo clima./Estação de Estrada de Ferro, Correio, Telégrafo./ Abernéssia - Campos de Jordão./ Telefone - Abernéssia n. 24”; 4 folhas; 28,5 × 21,5 cm; 2 furos.

${ }^{213}$ Trecho do artigo "Roberto" de Mário de Andrade. 


\section{Caro Décio -}

Logo segue carta.

O artigo de Geraldo Ferraz também irá.

Mostrei ao Quinquim sua carta. Ele vai lhe responder. O Quinquim está escrevendo uma peça - Chaminé.

O Hag ficou contente com sua opinião sobre o verso dele - "o melhorzinho", dado a ideia que ele faz de você, um erudito exigente, mto crítico e de mto gosto. Expliquei a ele que você era burguês e que possivelmente tinha se chocado um pouco.

Leiffer e Renato Viana vão escrever artigos sobre MOVIMENTO.

O artigo assinado G. é do Mário Guastini, ${ }^{214}$ pai do "pequenininho”. O Miguel recebeu uma carta dele. ${ }^{215}$

Tem feito mais sucesso a "Interpretação", o poema do Hag, "A Semana de Educação Sexual" e... (inesperadamente para mim) a seção Livros novos.

Abraços

\section{PauloEmílio}

São Paulo, 7 de [agosto] ${ }^{216}$ de 1935.

Ver páginas 5 e 15 - guarde a Súmula e esse número da Novela. Parece que a nossa crítica surtiu efeito. Esse número está bem melhorzinho e menos cafajeste. ${ }^{217}$

\footnotetext{
${ }^{214}$ Alfredo Mário Guastini (1884-1949), um dos maiores críticos do movimento modernista e de seus expoentes. É autor do conhecido A hora futurista que passou (1926), livro de crônicas dedicadas a ironizar o modernismo brasileiro.

${ }^{215}$ Nessa data PE, como se vê, ainda não havia recebido de Mário Guastini o recorte da matéria sobre Movimento acrescido do seguinte bilhete de 30 de julho de 1935: "Meu Caro Sr. Paulo Emílio, cumprimentos. Recebi o primeiro número de Movimento, acompanhado de seu amável recado. A impressão que Movimento me causou deixei-a nas 'sociais' do Diário de S. Paulo, de hoje, cujo recorte lhe remeto. Impressão sincera. Um aperto de mão do seu, M. Guastini” (Arquivo Paulo Emílio Sales Gomes/Cinemateca Brasileira. PE/CP 0035).

${ }^{216}$ A partir das informações contidas, o cartão deve ser de agosto e não julho, provavelmente PE se confundiu ao anotar o mês.

${ }^{217}$ Na seção Revistas de Movimento há comentários sobre essas duas revistas Súmula e Novela. Sobre a primeira, Isac Blion Martins escreve: "Essa esplêndida revista de Amador Cisneiros, que sintetiza o movimento intelectual e político do momento procurando cuidadosamente, entre as revistas e jornais do mundo, tudo que possa interessar ao povo brasileiro, encontrou finalmente numa fase de equilíbrio e
} 
Cartão datado: “S. Paulo - 7 - 7 - 1935”; manuscrito a tinta azul; papel pardo, timbrado: "Paulo Emilio”; 4 folhas (frente e verso); 6,5 × 10,5 cm..

\section{(14) PE}

\section{Querido Décio -}

Respondo à sua de 1/8 1935

Não pense que me desanimou com o seu silêncio maldoso sobre os meus desenhos, ${ }^{218}$ atitude essa, agora, coroada com uma referência irônica sobre essa faceta de minha personalidade artística. Lembro-me que, quando eu comecei a me dedicar ao canto, você dava gargalhadas, debochava, fazia comentários à socapa e etc. Hoje, entretanto, você dá graças a Deus de eu não estar aí em Campos, deixando, pois, você espantar os burgueses, sozinho, com sua vozica pelintra. Fiz esses comentários ao Paulo Afonso que os aprovou com seriedade.

O pessoal (Oswald de Andrade, Flávio de Carvalho, Geraldo Ferraz, Vera Azevedo $)^{219}$ de uma maneira geral não gostou da capa. Eu não a achei má, não. Pode ser que não tenha nenhuma "significação" mas é "expressiva". A não ser que seja produto do "inconsciente demoníaco" da Anita Malfatti, me parece que ela fez a capa com mta frieza (a frase está errada mas dá para entender). A propósito, se você me mandar mais um provérbio em suas cartas eu lhe escrevo uma que não poderá entrar para nossa "correspondência completa".

calma, justa recompensa para uma revista que no começo lutou desesperadamente." E, sobre Novela, julga: "Os editores dessa revista lembram sempre que possível que essa publicação foi feita para divertir os mortais e que, portanto, tem direito a exigir desses mesmos mortais alguma retribuição. E como neste vale de tristezas o que mais dá valor ao homem é o dinheiro, a redação, dando suspiros e olhares de resignação, aceita o vil metal..." (Movimento, p. 108 e 111).

${ }^{218}$ Desenho de PE enviado a DAP, em que retrata uma sala de cinema, com uma orquestra à frente da tela e os dizeres: "Supremo gozo artístico". Assinatura de PE com a data de "maio - 1935". É curioso, pois nesse período PE ainda não tinha relação estreita com o cinema, pelo menos declaradamente.

${ }^{219}$ Vera Vicente de Azevedo, colaboradora de Movimento. Seu nome consta na página de rosto como uma das "promessas" para o segundo número da revista, assinando o artigo "Ensaio sobre cultura". 
Qto à sua apresentação achei-a gelada demais para apresentar a revista. Já no segundo número irá mto bem.

Quanto ao "Manifesto" não creio que os espíritos burgueses se escandalhem com ele. Dá unicamente ideia de muito entusiasmo e novidade. Achei-o até de um “oportunismo" exagerado. Mas para o tom em que a revista saiu está bem. ${ }^{220}$

A propósito do "Manifesto" observei como nos conhecemos bem já. Quando escrevi aquela história dos "entrechoques e etc", lembrei-me de você, da "mentalidade privilegiada" da minha conferência sobre Vicente de Carvalho, ${ }^{221}$ e dei muita risada. Mas com franqueza: se bem que eu esperasse sua desaprovação nunca poderia imaginar que você desconfiasse de que eu tivesse conhecimento de que você não gostaria... Não é à toa que o Guastini se admira de que como nos enxergamos... Para mim isso é devido à prática adquirida com o pocker - fingir que se está blefando afim de que o outro percebendo o fingimento não jogue e a gente se salve pois se estava blefando mesmo.

Quanto ao seu lamentável "antiguismo" a que você, com tanta presunção, se refere nesse trecho será assunto, talvez, para uma carta inteira.

O artigo de Pontes de Miranda está mesmo confusíssimo. Está mesmo mto mais confuso que os seus livros (conheço dois) que já têm essa fama. Não obstante está interessantíssimo e, não sei se você sabe, é quase completamente original. Sobre essa evolução que a filosofia sofreu, existe alguma coisa escrita, mas isoladamente como "a

\footnotetext{
${ }^{220}$ PE termina o "Manifesto" de Movimento incitando o leitor: "Mande o seu artigo, a sua ideia, o seu ataque, a sua análise, o seu verso, a sua crítica, o seu conto, o seu ódio sincero, a sua profissão de fé, a sua propaganda. Mande o que você quiser, moço brasileiro! Mas mande! Porque Movimento é isso." (Movimento, p. 4). O pedido repercutiu em muitos estudos, textos, matérias, enviados através de cartas, segundo comprova a documentação conservada no acervo de PE na Cinemateca Brasileira. Dois bons exemplos são os trechos das cartas de Sebastião Almeida Oliveira, de 26 de julho de 1935, e de Eduardo Sucupira Filho, de 6 de agosto do mesmo ano. O primeiro deles escreve: "Agora que a mesma [Movimento] vem de sair a público resolvi escrever-lhe nova carta e desta vez acompanhada de ligeiro artiguete que ofereço à sua crítica. Como o amigo disse que aceitaria colaboração de todos, até de analfabetos... foi que me aventurei a remeter meu frágil ensaio, que em merecendo vossa proteção e boa vontade poderá ser publicado nas páginas seletas de vossa publicação destinada ao presente mas que enxerga o futuro." Sucupira Filho também responde ao apelo do "Manifesto": "Assim é que igualmente estimulado pelas últimas palavras do manifesto, em que o mesmo concita a que todo moço brasileiro envie o seu artigo, a sua ideia, o seu ataque, a sua análise o seu verso, a sua crítica, o seu conto, o seu ódio sincero, a sua profissão de fé, a sua propaganda, - escrevi e tomei a liberdade de enviar-lhe para que seja publicado, o meu trabalho anexo de nome - "A reação clerical". (Arquivo Paulo Emílio Sales Gomes/Cinemateca Brasileira. PE/CP 0034 e PE/CP 0043).

${ }^{221} \mathrm{PE}$ refere-se à homenagem feita pelos estudantes do Liceu a Vicente de Carvalho, na qual foi um dos oradores. José Inácio de Melo Souza historia: "Sua [de PE] palestra dita em voz 'cavernosa', segundo uma das revistas em que atuou como diretor, D. Quixote, versou sobre o tema 'Vicente de Carvalho e o mar'. (Paulo Emílio no Paraíso. Ed. cit., p. 48).
} 
propósito", em vários livros. Como trabalho especial sobre o assunto creio que pode ser considerado completamente original. (Essas observações, como você percebe, não são todas minhas, que não tenho conhecimentos para saber se esse artigo é original ou não). Li "Filosof. cláss. e filosof. científica" umas cinco vezes (contando com as correções de provas), e a parte que entendi, que foi grande, me interessou profundamente. Alguma coisa já tinha dentro de mim. Tinha pensado mesmo em escrever para a seção Ideias que imaginei criar no Movimento uns comentários em que eu diria que se a filosof. era antigamente a metafísica e a abstração, hoje era o materialismo histórico (parte filosófica) e o laboratório.

Leia o artigo mais vezes.

A "Interpretação" fez mesmo, conforme já lhe mandei contar, bastante sucesso.

Quanto àquele trecho de compra de armamentos e do navio nos Estados Unidos é mesmo, aparentemente, contradizente (ou contraditório). Esse folheto de onde eu traduzi esse artigo é um resumo feito de um documento da III Internacional. Tenho agora em mãos esse documento em francês. É mto mais desenvolvido, mais completo que o que conhecemos, que, aliás, está pessimamente resumido e escrito. Nessa parte da compra de armamentos, o autor, Labirse, diz que era de se estranhar isso, mas que o conhecimento um pouco aprofundado dos imperialismos nos esclarece a questão: tratase do seguinte - quando se fala em capitalismo inglês não quer dizer que pertençam a esse imperialismo, unicamente capitalistas ingleses, não. Trata-se de um bloco imperialista no qual, por questões, por assim dizer geográficas, a maioria é de ingleses, havendo outrossim representantes em toda parte do mundo. A fábrica que nos enviou armamento, a "Klazy Cia" pertence ao bloco imperialista britânico chefiado por Deterting. Por aí você vê que as armas vieram de uma fábrica americana que está ligada ao imperialismo britânico. O imperialismo não tem pátria. Pelo fato de nós também não termos é que o Chefe Nacional diz que socialismo e capitalismo é a mesma coisa...

Si tivesse tido a "Interpretação" no original eu teria feito um resumo mais claro e mais interessante do que esse que publicamos.

A sua hipótese sobre o surto algodoeiro em S. Paulo é interessante. Atualmente o capitalismo norte-americano anda agindo aqui em S. Paulo de uma maneira 
acentuadíssima. Já se desconfia que um dos encarregados oficiais desse assunto seja representante direto do capitalismo norte-americano. A força dos Estados Unidos já é tão grande que ele está tentando agora tirar as tarifas protecionistas de nossa indústria. Se isso acontecer será um descalabro. Dei a propósito disso uma entrevista para a Plateia. Mas essa foi entrevista mesmo. Veio o rapazinho aqui sentou-se na escrivaninha, eu fui falando e ele tomando nota. Por sinal que saiu pessimamente escrita, sendo, em alguns pontos, quase ininteligível. ${ }^{222}$

Os defeitos de tradução foram devidos à pressa com que foi feita. Eu com o original em espanhol na mão, lendo em português e o Rodolfo escrevendo a máquina. Era preciso entregar daí a 12 horas.

O artigo da Lúcia está realmente interessante. Achei o assunto e a opinião dela de mta oportunidade dado o aspecto de nossa revista. Estou ficando com uma grande admiração pela Lúcia Miguel Pereira. Tenho lido seus artigos, agora, com mais atenção e vou comprar os seus livros. ${ }^{223}$

Aquela hereditariedade simplista do Mário de Andrade creio que foi o meio mais simples que ele arranjou para dizer o que tinha de dizer. Quanto ao fato de você não ter enxergado muita coisa no livro lembre-se de que o Mário de Andrade disse que os moços formados espiritualmente depois da guerra não poderão compreender mta coisa de Roberto. ${ }^{224}$ Como você vê o seu "antiguismo" pedante não é tão acentuado assim...

\footnotetext{
${ }^{222}$ Referência à entrevista "Contra o imperialismo e o latifúndio", no jornal A Platéia, em 2 de agosto de 1935. Nesse texto, PE comenta o estudo que fez, com o colega Fernando Alayon, sobre a situação da classe operária no Brasil. PE discorre sobre as más condições dos trabalhadores nas fábricas, principalmente nas de tecidos. Segundo José Inácio de Melo Souza, a referência à indústria têxtil pode ser considerada uma acusação à própria condição burguesa, já que a família de PE tinha uma tecelagem em Sorocaba, a Companhia Fiação e Tecidos Santa Maria. O alvo da acusação fica evidente na matéria publicada em A Platéia, em 27 de agosto de 1935, enviada pelo "correspondente em Sorocaba", texto que, certamente, até pelo tom irônico, teria a mão de PE. Na abertura do texto, lê-se: "A principal coisa a se notar na Fábrica de Tecidos Santa Maria, de Sorocaba, é a falta de higiene mais criminosa que se possa imaginar. Dizem os operários que dela saem, todos os anos, tuberculosos e morféticos e isso é uma verdade fácil de se verificar." Nessa fábrica, PE situou a vida do pai de Hag Reindrahr.

${ }^{223}$ Em 1935, Lúcia Miguel Pereira, além dos artigos para Boletim de Ariel, já havia escrito dois livros: Maria Luísa e Em surdina, de 1933.

224 "Roberto é um dos livros mais notáveis do nosso romance contemporâneo. Sérgio Milliet abre ele com o depoimento duma geração. Os moços formados espiritualmente depois da Guerra, não poderão talvez
} 
Achei os seus comentários sobre "O Rabo e o Homem" absolutamente absurdos. E isso porque você critica com uma seriedade científica um artigo que evidentemente foi feito para provocar gargalhadas. E é por isso que é natural que as vantagens do rabo sejam forçadas. Você queria que ele começasse a fazer comentários sobre a vantagem que o fígado, ou o baço, ou os intestinos adquiririam se o homem tivesse rabo? Para fazer graça no caso é preciso procurar coisas exóticas, é por isso que ele apresenta um rabo peludo. ${ }^{225}$

O Hag gostaria de receber uma carta sua. Qdo você conhecer esse rapaz você verá que isso não tem nada demais. Escreva uma carta a ele. Pode mandar aqui para casa mesmo mas com a indicação Revista Movimento. Dê seus palpites (podem ser sinceros) sobre os versos dele.

Naquele trecho do meu artigo, que está mesmo confuso quis dizer o seguinte:

- S. Paulo, por ser o líder econômico tornou-se o líder político. Veio a revolução de 1930 e deslocou a liderança política de S. Paulo para o Rio Grande e Norte. Isso determinou uma situação artificial: S. Paulo continuava como líder econômico e não era mais líder político. É por isso que eu disse "esse súbito e transitório deslocamento, unicamente político, sem articulação na realidade econômica”. Quando for para a feitura de minhas obras completas você faça o favor de esclarecer esse ponto.

A primeira frase do artigo do P. de Miranda não está truncada, não.

Até o Miguel gostou do artigo do Flávio. Você escreveu Fernando.

compreender já, o valor documental de Roberto. Nem este representa, a meu ver, todo o problema das gerações formadas de 1890 a 1910”. (Mário de Andrade, Movimento, p. 48).

225 "Praticado um orifício em suas calças, ele anda garboso, porte atlético, o peludo rabo oscilando com ritmo, elevado por detrás de si num gesto arrogante" (“O rabo e o homem”, Movimento, p. 51). 
O Quinquim vai lhe escrever uma carta respondendo aos seus comentários sobre a crítica dele.

Concordo com você de que a "cozinha" está mal feita. Também foi feita exclusivamente por mim, de um só fôlego, em dois dias, ao mesmo tempo que a crítica de livros novos, revistas, manifesto e tudo o mais que está espalhado pela revista. Não dá impressão de "por atacado"? Eu acho que sim.

Eu não achei as entrevistas tão cacetes assim, primeiramente a do Otokar Fisker e da Margaret Ludwig.

Eu não neguei "Conhecimentos sobre Álvares de Azevedo" a Vicente de Azevedo. Eu neguei “conhecimentos" a ele.

Quando li na revista a parte Revistas achei mesmo muito vasto os adjetivos empregados na gabação da $R$. Contemporânea. ${ }^{226}$

O número 5 da Novela traz resposta aos nossos comentários além de pilhérias com meu nome e o do Isac Blion Martins.

Aquele rapaz que meteu pau no Ag. Grieco ${ }^{227}$ numa reunião da Álvares é o João de Barro (nome é Osmar Pimentel) que eu chamo de bobo no comentário sobre o Boletim. ${ }^{228}$ Ele está louco para conhecer o Isac. Tenho estado com o Osmar Pimentel. É

\footnotetext{
${ }^{226}$ Os adjetivos utilizados são: "melhor revista do Brasil", "magistral artigo", "artigo formidável", "artigos bons", "interessantíssimo inquérito", "seções esplêndidas", "formidável número". (Movimento, p. $110)$

${ }^{227}$ Agripino Grieco (1888-1973) "enveredando pela crítica literária tornou-se autor de verve satírica, não havendo escritor que não lhe respeitasse a opinião, por ser sincera. Poeta, crítico, ensaísta, conferencista, e tudo o mais proveniente do espírito lúcido, foi dos escritores mais respeitados do Brasil". (MENEZES, Raimundo de. Dicionário literário brasileiro. Ed. cit., p. 315).

${ }^{228}$ Em Movimento, uma das revistas comentadas por Isac Blion Martins, na seção Revistas, é Boletim de Ariel. Na resenha se lê: "Muitos bobos (João de Barros, Francisco Patti e etc.) consideram essa revista como uma capela em que Agripino Grieco atua como sacristão." (Movimento, p. 112). É importante notar
} 
um rapaz interessante e de bastante cultura literária. Vou levá-lo juntamente com o Zuccoloto $^{229}$ e o Sangirardi ${ }^{230}$ para o Quarteirão, nome de tal organização de cultura de que lhe falei.

Quanto à recepção que Movimento está tendo e a saída foram um pouco melhor do que esperava. A venda nas bancas não tem sido mto insignificante.

Sua carta já está respondida. Amanhã eu lhe escreverei uma.

Mandei-lhe hoje cedo um livro sobre o Machado. Comprei um exemplar para mim. Pelas espiadas que dei parece ser interessante. Pelo menos não é livro de devoto. $^{231}$

\section{Um abraço do \\ Paulo Emílio}

São Paulo, 8 de agosto de 1935.

Carta datada: "S. Paulo, 8- / 8 - 1935"; autógrafo a tinta azul; papel branco, timbrado: "MOVIMENTO - revista do presente que enxerga o futuro"; 12 folhas; $28 \times 21 \mathrm{~cm}$.

\section{(15) DAP}

[Campos do Jordão], 10 de agosto de 1935.

Paulo Emílio,

Não pude responder antes a sua carta porque faltou selo em Abernéssia.

\footnotetext{
que, sendo a seção inteiramente assinada por Isac Blion Martins, PE assume a autoria dos textos ao escrever na carta "que eu chamo de bobo".

${ }^{229}$ O poeta, jornalista e advogado Afrânio Zucolotto (1913-1997) formou-se em Direito na Universidade de São Paulo, em 1935, ano em que começa a amizade com PE, que durou por toda a vida. Membro da Academia Paulista de Letras fez parte do conselho consultivo da Cinemateca Brasileira. São de sua autoria os livros Poemas (1948), Episódio do soneto (1966), entre outros.

230 Ângelo B. Sangirardi Jr. (1912-?). Estudante de Direito na Universidade de São Paulo em 1935, ligouse a PE por meio de Oswald de Andrade. Mais velho, dedicou-se ao estudo de plantas e folclore brasileiro. Manteve um programa de rádio chamado "Cartazes do mundo", no qual entrevistou intelectuais como Flávio de Carvalho e Oswald de Andrade. São de sua autoria alguns livros como: Deuses da África e do Brasil: candomblé e umbanda (1988) e Flávio de Carvalho, o revolucionário romântico (1985).

${ }^{231}$ Refere-se ao livro Machado de Assis de Augusto Meyer, publicado pela José Olympio em 1935.
} 
Quanto às contestações que V. faz às minhas críticas a respeito das entrevistas, deixo a discussão para S. Paulo.

Recebi também a outra carta com o recorte do tal G., que não sei quem é. ${ }^{232}$ É uma crítica bastante simpática a nós. Quem será os ultra-passadistas que recebemos com os braços abertos, de que ele fala? Será o Pontes de Miranda? V. recebeu os elogios do artigo. Ele diz: "agrada quando nada pela maneira destabanada com que os autores manifestam seu modo de pensar". Esses autores, ao que eu saiba, são o Quinquim Maurity, Isac Blion, etc., isto é, você.

Vi por uma carta do Paulo Afonso que V. recebeu a minha carta em que mandava a "Apresentação" e os comentários ao Movimento. Espero carta sua a respeito. Espero também novos recortes. Você sabe que tudo quanto for sobre o Movimento, me interessa. Por exemplo, o mito da venda.

Não me importo com a opinião do tal F.M.A. É um dos sujeitos mais ilegíveis que conheço, uma espécie de Zé Feliciano, aquele d'O Estado.

Não mande só recortes de jornais mas também impressões pessoais.

Estou fazendo umas notas sobre o Agripino para depois compor o artigo, o que então será mais fácil. Os pontos contestados ou comentados das páginas da Evolução são, por enquanto, um número de quinze.

Li A vida de Mirabeau, ${ }^{233}$ que V. me emprestou daquela coleção. É bastante interessante, mesmo porque o assunto por si só é interessantíssimo.

A respeito do Movimento, tenho ainda a dizer que não havia preço marcado nele. Achei graça nas forças (prazer e desprazer) que não se combinam, etc. Quando o Tranchesi dava aquelas aulas de física, decerto nunca pensou que estava te dando uma figura literária.

Mande-me outro Movimento que o meu já foi colocado.

Que tal V. achou a "Apresentação"? ${ }^{234} \mathrm{Eu}$ ainda quero fazer um bom acréscimo nela, mas isso só quando estiver em S. Paulo, com as minhas notas a mão (dá a impressão de erudição?).

Perdoe-me a indiscrição, mas quais são os componentes dessa famosa geração dos "novíssimos" tão falada em entrevistas e de quem o Oswald gosta tanto?

\footnotetext{
${ }^{232} \mathrm{DAP}$, provavelmente, ainda não havia recebido o cartão de PE de 7 de agosto em que anuncia que o tal "G” é Mário Guastini.

${ }^{233}$ Menção à biografia La vie orageuse de Mirabeau, de Henry de Jouvenel, publicada em 1928 pela Librairie Plon, na França.

${ }^{234}$ DAP, provavelmente, ainda não havia recebido a carta de PE de 8 de agosto em que este faz comentários sobre a "Apresentação".
} 
Tenho uma boa notícia a dar ao Cassino. A família portuguesa dos vinhos, de que devo ter falado em alguma carta, deixou-me 4 garrafitas de bom vinho, que iremos beber no Cassino. Duas são Bourgogne, daquela generosa colheita de 915 e as outras são da Companhia Velha.

Agora vai uma revelação que me enche de vergonha. Tive pela primeira vez um apelido: "mimoso", devido aos meus elegantes saltos no jogo da peteca e aos meus dotes de salão. Com os hóspedes o apelido lá se foi, haverá um mês.

Nada transpirou ainda a respeito do casamento da Nely? Procure informar-se com o Hugo. ${ }^{235}$ Forçosamente deve haver alguma coisa.

Reparei na alegria e no tom de desprezo com que V. e o Paulo Afonso falam no meu erro da maleita: "asneira grossa", "asneira que você afirmava", etc... "ah! a vingança dos anões, pisar na sombra!"

Por hoje é só.

Lembranças à turma e V. receba um abraço do

Décio

Carta datada: "10-8 - 935"; autógrafo a tinta preta; papel pardo; 3 folhas; 26,5 × 20,5 cm; 2 furos.

(16) DAP

[Campos do Jordão], 12 de agosto de 1935.

Paulo Emílio,

Esta carta vai rápida para poder apanhar o correio. Depois irá outra em resposta a sua.

Recebi a Súmula e o livro sobre Machado que é interessantíssimo e muito agudo. É o trabalho sobre Machado que mais me agradou até hoje. Farei uma crítica para o Movimento expondo as minhas ideias a respeito, que elas existem. Recomendo a V. a

\footnotetext{
${ }^{235}$ Hugo Nascimento Gama, colega dos correspondentes no Liceu e nas publicações ginasiais A Quinzena (1932), Revista Rio Branco (1933) e D. Quixote (1933).
} 
leitura do tal livro Livro de San Michele, ${ }^{236}$ anunciado no livro, é um dos maiores sucessos de literatura ultimamente. Papai que o leu em francês gostou muito.

Estou desconfiado que o tal Hag é você. Não pelo verso, mas pelas suas cartas. A tal história do judeuzinho inteligente que quer me conhecer, que quer receber carta minha etc, pode ser verdadeira mas tem todo o aspecto de um conto de vigário, imaginado com detalhes. A Súmula elogia no verso o jogo de contraste. A coisa verdadeiramente interessante que encontrei nela foi a serenidade irônica com que fala por "obra de Deus", "também por obra de Deus". ${ }^{237}$

A citação vai de memória que o meu Movimento está dado, Mande-me outro.

Os elogios que faço ao livro sobre o Machado valem por agradecimentos a você.

Espero carta do Quinquim com sofismas.

Espero também a sua carta com os recortes do tal sujeito do Diário da Noite, notícias do Guastini, etc.

Abraços do amigo,

Décio

Carta datada: "12 - 8 - 935"; autógrafo a tinta preta; papel branco, manchas por oxidação; 2 folhas; $26,5 \times 20,5 \mathrm{~cm} ; 2$ furos.

\footnotetext{
${ }^{236}$ O Livro de San Michele, autobiografia do médico sueco Axel Martin Fredrik Munthe, publicada em 1929.

${ }^{237} \mathrm{O}$ trecho alude a versos do poema "Trecho de vida" de Hag Reindrahr: "A mulher do gerente era uma beleza./Também, por obra de deus, era burguesa" e "A mulher do desempregado era uma pária./Também, por obra de deus, era operária". (Movimento, p. 62).
} 
(17) PE

[São Paulo], 13 de agosto de $1935 .^{238}$

Décio -

Arrebentou um ótimo escândalo! $!^{239}$

Viva! A história é formidável! Mandarei-lhe os recortes seguintes. Paulo Emílio

Cartão datado: "13 - ag. 935”; manuscrito a tinta azul (no verso); papel pardo, timbrado: "Paulo Emílio”; 1 folha; $6,5 \times 10,5 \mathrm{~cm}$.

(18) PE

São Paulo, 17 de agosto de 1935.

Caro Décio,

O Paulo Emílio me mostrou a carta em que você faz uns comentários sobre a minha nota-crítica a respeito do Sexo do Renato Viana...

Você diz logo de cara que meu artiguete é fraco e exagerado. Quanto à "fraqueza" fica meio besta eu argumentar, e, sinceramente, eu também acho um pouco...

Eu não concordo com o exagero que você me atribui. Por eu dizer que teatro-

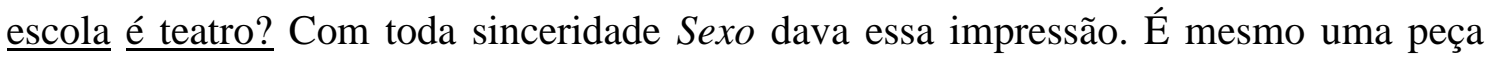

\footnotetext{
${ }^{238}$ Cartão reproduzido no Anexo.

${ }^{239}$ Movimento ficou conhecida e ganhou certa projeção na imprensa dado o "escândalo" travado em torno de sua publicação. O bibliotecário do Conservatório Dramático e Musical de São Paulo, Nestor de Assis Ribeiro, chamou a revista de "imoral e dissolvente (...) com palavras que ofendem o decoro" e rasgou o periódico em público. PE irritado com o fato, mas também se aproveitando dele para uma maior divulgação da revista, ventilou no Diário da Noite, de São Paulo, em 12 de agosto de 1935, carta na qual desafiava o bibliotecário: "Sr. redator, tendo tido conhecimento de que o Sr. Nestor Assis Ribeiro, bibliotecário do Conservatório Dramático e Musical de S. Paulo, rasgou a revista Movimento que a redação enviou a esse instituto de cultura, além de dizer que esse órgão da mocidade de $\mathrm{S}$. Paulo é 'imoral e dissolvente'. Convido o Sr. Assis Ribeiro a provar ou desmentir o que disse, e em caso contrário, desafio-o para um duelo a tapas. Ficarei grato pela publicação desta. Paulo Emílio Sales Gomes". Além do Diário da Noite, outros jornais deram a notícia: $O$ Diário de S. Paulo, O Jornal e $O$ Globo no Rio de Janeiro, todos do dia 13 de agosto de 1935.
} 
muito boa. Qdo assisti a outras peças do repertório eu me convenci de que Sexo é uma peça mto boa e o teatro-escola é uma droga. Isso porque eles saíram da linha que Sexo seguiu.

Na segunda parte você, fazendo uma grande confusão entre eu e o Paulo Emílio, você estranha que eu não tenha dito que o teatro de Renato Viana é anti-popular e etc. Mas o caso, Décio, é que esse teatro não é completamente anti-popular, como por exemplo, o ridículo e decadente teatro francês que o Procópio ${ }^{240}$ leva traduzido aqui no Brasil. Absolutamente. Você pouco adiante para argumentar sobre a "não popularidade" de Sexo diz que é uma peça freudiana. Então pelo fato de ser freudiana, não pode ser popular e mesmo de massas, esse teatro? Não entendi você nisso...

Ao contrário do que você pensa, a ação no Sexo não foi totalmente relegada em segundo plano. Isso só acontece nuns determinados momentos.

Quanto a esse trecho de sua carta "Se houver tese, a ação é que deve demonstrála sem auxílio dum sujeito muito inteligente que explica tudo ao público", quanto a esse trecho eu para lhe responder, transcrevo uma parte do meu artigo, ficando demonstrado que nesse ponto estamos de pleno acordo. Eis o trecho - "A tese em que se articula o enredo é por demais contada. Poderia ser explicada pelo próprio enredo. O Dr. Calasans sentado num sofá, doutrinando chega a cacetear. Faz a gente sair da peça e reparar num homem que está sentado num sofá explicando uma história qualquer”.

$\mathrm{Eu}$, como você sabe, nunca fiz crítica de teatro concordando que isso não seja cá comigo, mas discordando que seja com você.

Eu fui ao Sexo gostei e reparei em certas coisas. Cheguei em casa elogiei a peça e acentuei, comentei as coisas em que tinha reparado mais. Concordo que faltou muito um certo pedantismo de entendido. O Renato conversando como Paulo Emílio disse que tinha gostado muito de eu ter acentuado a figura da irmã do Dr. Calasans e a dança no meio da peça, duas coisas que ele considera importantíssimas em Sexo e nas quais nenhum crítico reparou.

Transcrevo aqui o trecho de uma carta que o Renato mandou ao Paulo Emílio e você (lembra-se do Alves Filho com as cartas do Procópio e Joracy?): ${ }^{241}$

\footnotetext{
${ }^{240}$ Procópio Ferreira (1898-1979), ator cômico de muito prestígio no teatro brasileiro.

${ }^{241}$ Refere-se, provavelmente, ao colega de turma no Liceu, Francisco Martiniano Rodrigues Alves Filho e aos atores de teatro Procópio Ferreira e Joracy Camargo (1898-1973).
} 
“...na parte que me interessa pessoalmente: a crítica de Joaquim Mauriti a Sexo. É uma página colorida, nova, de pontos de vista cintilantes, grande visão cênica e maior agudeza sintética de análise profunda... (concordo que isso tudo é falação).

Mauriti ressaltou detalhes, focalizou intenções que tinham passado completamente escondidas à percuciência geral. Entretanto, que eu saiba, Joaquim Mauriti nunca fez crítica teatral. É um valor novo que Movimento impele na sua saída para a frente..."

Disse-me o Paulo Emílio que o Renato quer mto me conhecer. Vou aparecer lá qualquer dia desses.

Estou escrevendo uma peça - Chaminé - Tem algumas tiradas completamente originais. O Paulo Emílio gostou muito. Vamos ver... ${ }^{242}$

Seguindo o exemplo do Paulo Emílio, de quem não consigo me afastar, em tudo, por mais que faça força, digo que tinha mais assunto, mas... etc.

Um abraço do seu,

\section{Quinquim}

Carta datada: “S. Paulo - 17 - agosto - 1935”; manuscrito a tinta azul; papel branco pautado; 5 folhas; $26,5 \times 20,5 \mathrm{~cm}$.

\footnotetext{
${ }^{242}$ No arquivo de PE, conserva-se o manuscrito, de três páginas, Chaminé - peça em dois atos em meio. O texto está organizado em três partes: personagens, ambiente e atos. As personagens são Anjo Gabriel (operário católico, místico, velho, 60 anos), José Martins (filho do Anjo Gabriel, comunista, 20 anos), Maria Martins (irmã de José Martins, operária, namoradeira), Pentarca Martins (mãe de Maria Martins, 55 anos) e Décio Oliveira (amigo de José Martins, operário comunista, inteligentíssimo e culto, 20 anos) - evidente alusão ao estudante Décio Pinto de Oliveira, morto com um tiro na cabeça durante o confronto entre a frente da esquerda e os integralistas, em 1934. O ambiente é uma sala de jantar e quarto da casa da família operária Martins. A peça encena a família acordando com o barulho da "fábrica apitando" e da "chaminé fumegando" (origem do título). A cena se constrói em torno da explicação do nome da matriarca, Pentarca, sobre o qual o público solta "uma grossa gargalhada". Logo depois da gargalhada uma voz bem forte explica: "Pentarca nasceu numa fazenda em Minas Gerais. Seus pais, dois colonos resolveram por nessa filha, que era a primeira, o nome de Maria que eles achavam muito bonito. Os donos desta fazenda estavam nesse tempo com hóspedes muito alegres e brincalhões. Os donos da fazenda resolveram divertir os seus hóspedes e convenceram o casal de que deveriam das à filha o nome de Pentarca. Durante uma semana divertiram-se imensamente vendo as dificuldades dos caipiras em dizer Pentarca. Por isso é que a mulher do Anjo Gabriel em vez de se chamar Maria chama-se Pentarca" e dito isso o coro de gargalhadas do público volta a aparecer. (Arquivo Paulo Emílio Sales Gomes/Cinemateca Brasileira, PE/PI 0063).
} 
(19) PE

São Paulo, 21 de agosto de 1935.

\section{Caro Décio,}

Não há muito o que responder nas suas cartas de 10 e 12 de agosto.

Fiquei satisfeito de saber que você gostou do livro que lhe mandei. Eu já o li e também gostei bastante. Fiquei com impressão de que a série de críticas que você tem sobre o Machado é uma droga, dado o seu entusiasmo pelo livro de Augusto Meyer, livro, que se bem que muito interessante, não esperava que fosse a melhor crítica sobre Machado que você já tivesse lido. ${ }^{243}$ Aliás um dos mais famosos trabalhos sobre Machado de Assis que é o do Pujol, ${ }^{244}$ eu o conheço e não tenho por ele nenhum encantamento. Estive em casa do Hugo outro dia (ele se mudou. Mora agora perto do Miguel. O Hugo ganhou uma parte da biblioteca do Nestor Rangel Pestana) e encontrei uma coletânea de conferências, feitas na Sorbonne, sobre Machado de Assis. O volume que comentei tem um prefácio do Anatole France. Você conhece isso? Creio que ele vai te dar o livro.

Eu e o Hag demos muita risada com suas dúvidas. Ele ficou besta com sua desconfiança. Eu lhe expliquei que a culpa era minha. Para acabar com suas desconfianças eu the aconselhei que lhe escrevesse uma carta em primeiro lugar.

Quanto aos novíssimos tenho a dizer-lhe que somos eu, você, Paiva Dutra(1), Osmar Pimentel(2), Zuccoloto, Sangirardi, Zé, Oswald de Andrade, umas meninas literatas, Paulo Afonso (que anda louco atrás de conhecimentos gerais sobre pintura desde o dia que deu uma "gafe" no atelier do ceramista Quirino da Silva) ${ }^{245}$ e etc...

Agora, sinceramente, você sabe Décio o que é que eu considero a novíssima geração aqui em São Paulo, unicamente eu e possivelmente você. Esse trecho dessa carta deve ser guardado com grande descrição.

\footnotetext{
243 O início da carta é com letra diferente da de PE, que inicia nesse ponto.

244 Referência ao livro do crítico literário e jornalista Alfredo Pujol (1865-1930), Machado de Assis, editado pela José Olympio, em 1934. O livro é composto de sete conferências sobre o autor de Memórias póstumas de Brás Cubas, no curso ministrado por Pujol na Sociedade de Cultura Artística de São Paulo entre os anos de 1915 e 1917.

245 Além de ceramista, escultor e pintor, Quirino da Silva (1902-1981) foi crítico de artes plásticas no jornal Diário da Noite. Um de seus quadros mais conhecidos, $N u$, de 1943, está exposto no Museu de Arte Contemporânea da Universidade de São Paulo.
} 
No que se refere aos vinhos tenho a dizer-lhe que gostei daquela sua tirada literária sobre "a colheita generosa de 915 ".

Quanto à Nely e ao Melo Jorge conto-lhe que estive com eles domingo passado, em casa do Hugo. Usei de todos artifícios para afogar meu embaraço: falei em voz alta, fiz pilhérias com D. Noêmia, dei grossas risadas, contei que descendia de mulatos, meti o pau em algumas tias, cantei, "flertei” a irmã do Hugo, mas... tudo isso foi inútil num momento em que a Nely sentou-se no colo do Melo Jorge. Eu estava de costas e quando me virei dei com essa cena. Levei um grande choque e fiquei rubro. Por cúmulo na mesa, na hora do lanche aconteceu uma que me desmontou. Imagine que estava o pai do Hugo brincando com a hipótese da Nely ficar viúva cedo e eu bestamente digo que gostaria de me casar com uma viúva. Foi um frege doido. O pai do Hugo cheio de verve insistiu na história um colosso de tempo, disse que agora era tarde, que eu deveria ter me habilitado há mais tempo e etc. Imagine minha cara. Daí há uns minutos eu estive durante algum tempo só com a Nely e a irmã do Hugo. E você acredita que quando eu dei acordo de mim estava rememorando coisas, dando indiretas, [ilegível]. Nunca senti tanto ódio de mim mesmo. Eu ainda não me acostumei com essa ideia do casamento do Melo com a Nely. É perturbador, acredite.

O tal clube de que lhe falei o "Quarteirão" vai caminhando. Sábado tivemos um almoço do qual compareceu bastante gente. Na minha frente sentou-se Sérgio Milliet ${ }^{246}$ com quem conversei bastante. Gostei mto dele. Tem um jeitinho recatado e modesto. Parece conhecer bastante literatura brasileira. Sexta-feira próxima nos reuniremos em casa de D. Vera (acho que já lhe falei nessa interessante senhora). ${ }^{247}$ O Paulo Afonso tem estado presente a todas essas coisas. No sábado mesmo fomos ao banquete oferecido ao Renato Viana. Lá entre outras coisas interessantes o Flávio de Carvalho pôs um senhor malandro, que dizia gracejos a uma senhora, para fora; eu fiz uma saudação em homenagem ao Renato em nome de MOVIMENTO; e trouxemos uma banda de música que estava percorrendo as ruas da cidade fazendo anúncio do [ilegível]

\footnotetext{
${ }^{246}$ A respeito do crítico e escritor Sérgio Milliet (1898-1966), DAP declarou em seu testemunho sobre Mário de Andrade: "Se o Mário era, vamos dizer o chefe, se Oswald era o opositor, o Sérgio Milliet seria o mediador e o árbitro. Isto é, ele era o crítico, era o equilíbrio. [...] Eu aprendi muito com Sérgio Milliet, porque ele escrevia muito em jornal, era um jornalista ótimo, escrevia sobre pintura." (LOPEZ, Telê Ancona (org.). Eu sou trezentos, eu sou trezentos e cincoenta (Mário de Andrade visto por seus contemporâneos). Rio de Janeiro: Agir, 2008, p. 102).

${ }^{247}$ Vera Vicente de Azevedo, anteriormente citada.
} 
para tocar um pouco em honra ao Renato. Foi uma verdadeira apoteose popular com choradeira e etc.

Ótima criatura o Renato Viana. Tornei-me um bom amigo dele. Ele parece-me uma criatura idealista e sincera. As peças dele são cheias de chavões e lugares-comuns, mas eu creio que muitas vezes ele é obrigado a isso, pois julga que a massa o exige. Creio que ele está errado. A massa não exige coisa nenhuma lugares comuns; ela quer emoções. É um homem bem avançado, apoia nitidamente a esquerda. Tem grandes conhecimentos sobre teatro. Aprecia enormemente e sente não poder levá-lo aqui, o teatro soviético. Não achei o tal Deus tão absurdo assim. Tem até muita coisa boa. Não achei a peça clerical. Trata-se em Deus de um sábio materialista mas de formação burguesa que num momento de desespero fica místico assim como, em outras condições, poderia ter ficado anarquista. O Renato Viana vai ficar um de nossos colaboradores. Ele gostou imensamente da revista. Ele nos escreveu uma carta em que se refere principalmente à crítica do Joaquim Mauriti que apreciou bastante.

Conheci há dias, no Estado o Armandinho. ${ }^{248}$ Tive uma má impressão dele. Vive exibindo cultura, é muito pedantinho, muito francês, e muito "filho do presidente do Estado". Se preocupa imensamente na procura de bons efeitos: qdo eu ia me retirar ele me fez esperar mais cinco minutos afim de me contar um caso mto fino e interessante do Marechal Gafore. Acabado isso ele me cumprimentou rapidamente e retirou-se triunfante... Tenho certeza de que se tivesse uma cortina atrás ele repetiria as cenas do Ibrahim no Júri.

Ele me diz meio entendido em leitura de mãos. Entreteve-se com a minha durante uma meia hora e disse-me coisas realmente curiosas. Conversamos quase o tempo todo sobre comunismo. O Armandinho tem certeza de que caminhamos para uma revolução proletária. Disse-me que eu o encontraria do outro lado da barricada... Perguntei se ele não achava que os revolucionários teriam razão. Respondeu que tinham mas que ele pessoalmente devia tudo que era ao Pai, devia ao Pai a biblioteca que tinha

\footnotetext{
${ }^{248}$ Armando de Salles Oliveira Filho (1912-1986), filho de Armando de Salles Oliveira, governador do Estado de São Paulo entre abril de 1935 e dezembro de 1936 e um dos sócios do jornal $O$ Estado de $S$. Paulo. PE voltou a encontrar Armandinho na França, no exílio, como explica José Inácio de Melo Souza: "[...] em novembro de 1937, a elite paulista derrotada exilou-se em Paris (o candidato Armando de Salles Oliveira, Júlio de Mesquita Filho, Paulo Duarte e Paulo Nogueira Filho). PE e DAP, no final de 1938, foram convidados pelo filho de Armando Salles para um jantar no apartamento da rue Anatole de La Forge". (Paulo Emílio no Paraíso. Ed. cit., p. 118)
} 
e etc., e que por isso estaria do lado da burguesia até a morte, pois que tinha certeza de que se não morresse durante o combate, morreria depois, fuzilado... Ele costuma muito ter dessas tiradas...

Pelo que me contou ele deve estar com uma ótima biblioteca, pelo menos no que se refere a comunismo. Ele me disse, a propósito de nada, que se ele quisesse escreveria todo dia no Estado, e que se não faz isso é por falta de assunto. Disse que tem a vantagem de não ter a vaidade de publicar livros, ainda mocinho (!) Versos ele publicou mas para isso, acrescentou, não é preciso cultura.

Tenho impressão de que conhecendo-o melhor gostarei mais dele. O Schmidt ${ }^{249}$ me assegura isso.

O Oswald de Andrade tornou-se um bom amigo meu. É uma ótima criatura muito inteligente e bem engraçado. Não sei dizer ainda se ele é culto ou não. Parece bem menos do que dizem. Segundo me disseram uns entendidos Oswald de Andrade é que é o verdadeiro renovador da literatura brasileira. Fizeram contra ele uma campanha de silêncio que durou 3 anos e que só foi rompida agora por Jorge Amado e pelo grupo novo do Rio.

Oswald de Andrade apesar de seu espírito de "frege", creio ser um ótimo elemento para o “Quarteirão”. Ele é muito entusiasmado e tem muita ideia interessante.

O Schmidt, com quem ultimamente tenho tido certo contato, é um homem sossegado, frio, calculador e inteligente. Conhece marxismo muito bem. Tenho me encontrado com ele nas conferências da Universidade. Eu julgava o Schmidt um burguesinho qualquer, redator d'O Estado e que falava em comunismo. Refundi completamente a minha ideia. O Schmidt é um ótimo elemento e nem sequer lê $O$

\footnotetext{
${ }^{249}$ Afonso Schmidt (1890-1964), jornalista e escritor paulista que, desde 1924, atuou em $O$ Estado de $S$. Paulo, sendo, segundo DAP, o "o único comunista da redação" ("Paulo Emílio quando jovem". Seres, coisas, lugares (Do teatro ao futebol). Ed. cit., p. 159). Amigo de PE, Afonso Schmidt apoiou a Comissão Organizadora dos "Direitos da Mocidade", junto com Guilherme de Almeida, Colbert Malheiros e Claude Lévi-Strauss. A Platéia, em 18 de setembro de 1935, noticiou o evento: "Realizou-se ontem a primeira reunião para tratar dos direitos da mocidade. [...] O conferencista [PE], em vibrante análise, salientou o papel vanguardeiro da juventude, na luta pela democracia: 'A luta das novas gerações, não é apenas a luta pela conquista de uma vida melhor. É também, diante da ofensiva das tendências reacionárias, diante da guerra, do desemprego e do facismo, a luta pela própria conservação da vida, pelos direitos ameaçados, pelas liberdades esmagadas, por tudo que nos foi legado e que agora ameaçam arrancar das nossas mãos, para nos entregar inermes, nas mãos do absolutismo fascista”".
} 
Estado... Ele me informou que o O.F. é um anarquista libertário exaltado. Você sabia disso?

Conheci ainda, com essa historiada toda de revista e clube o Jaime Adour da Câmara, ${ }^{250}$ Prof. Lévi-Strauss (sociologia/universidade) ${ }^{251}$ o gravador John Graz, ${ }^{252}$ o músico [Frank] Smith, o escultor Brecheret ${ }^{253}$ e etc, etc, etc.

Um rapaz interessante que anda aqui por S. Paulo é um tal Guilhermo Hohagen ${ }^{254}$ representante da Crítica no Brasil.

Guarde a Súmula, a Novela, e as entrevistas que lhe mandei. Essas fotografias que vão hoje, também devem ser devolvidas.

Deixo o que mais houver para contar, a cargo do P.Afonso que tem mais tempo do que eu.

Fiquei alegre de saber que você já está tratando do seu artigo para o próximo número. E a conferência? Escreva-me sobre ela. Um grande abraço amigo do

\section{Paulo Emílio}

Os outros recortes e artigos sobre Movimento você verá aqui em S. Paulo.

(1) Aquele da Álvares de Azevedo parecido com o Procópio.

(2) Aquele da Álvares de Azevedo parecido com o Agripino Grieco.

Carta datada: "S. Paulo, 21 - ag - 1935"; manuscrito a tinta azul; papel branco; 7 folhas; 26,5 × 20,5 $\mathrm{cm}$.

${ }^{250}$ O jornalista Jaime Adour da Câmara (1898-1964), ligado ao movimento modernista, foi um dos diretores da segunda fase da Revista de Antropofagia, em 1929, junto com Oswald de Andrade e Raul Bopp.

${ }^{251}$ Sobre o antopólogo e professor francês Claude Lévi-Strauss (1908-2009) e sua passagem pela Universidade de São Paulo, nos anos de 1935 a 1939, como integrante da missão francesa no Brasil, DAP declarou na entrevista "Três encontros com Décio de Almeida Prado": "[...] Ele dava uma espécie de aula de como funciona a cabeça de um homem de primeira qualidade. Nós tínhamos uma grande admiração por ele. [...] Da França ele voltou direto para o interior do Brasil. Mas Lévi-Strauss dava aula exatamente sobre o que veio a escrever depois, que é sociologia primitiva". (A crítica cúmplice - Décio de Almeida Prado e a formação do teatro brasileiro moderno. Ed. cit., p. 296).

${ }^{252}$ O pintor e escultor suíço John Graz (1891-1980) foi um dos artistas plásticos ligados ao modernismo no Brasil.

${ }^{253}$ Victor Brecheret (1894-1955), escultor ítalo-brasileiro ligado aos modernistas; participou da exposição de artes da Semana de Arte Moderna em fevereiro de 1922.

254 O jornalista Guillermo Renan Hohagen esteve no Brasil entre agosto e setembro de 1935, acompanhado de Oswald de Andrade, que o convidou para a diretoria de "Quarteirão". Sobre ele PE vai escrever: "[...] Mas havia um táxi com um chauffeur japonês que era como se fosse dele [Oswald de Andrade]. Nesse automóvel é que circulávamos. Íamos a Itu na companhia da poetisa Julietta Bárbara e de um peruano, Guillermo Hohagen, amigo de Raul Victor Haya de La Torre e representante dos apristas refugiados em Buenos Aires". ("Um discípulo de Oswald em 1935". Crítica de cinema no Suplemento Literário, v. 2. Ed. cit., p. 442-3). 


\section{Bibliografia}

\subsection{Paulo Emílio Sales Gomes: obra e fortuna crítica}

Obra

GOMES, Paulo Emílio Sales \& TELLES, Lygia Fagundes. Capitu. São Paulo: Cosac Naify, 2008.

GOMES, Paulo Emílio Sales. Cemitério. São Paulo: Cosac Naify, 2007. . Cinema: trajetória no subdesenvolvimento. São Paulo: Paz e Terra, 1986. . Crítica de cinema no Suplemento Literário, v. 1. Rio de Janeiro: Paz e Terra, 1981.

. Crítica de cinema no Suplemento Literário, v. 2. Rio de Janeiro: Paz e Terra, 1981.

. Humberto Mauro, Cataguases, Cinearte. São Paulo: Perspectiva, 1974. . Três mulheres de três Pppês. São Paulo: Cosac Naify, 2007. . Vigo, vulgo Almereyda e Jean Vigo. São Paulo: Cosac Naify, 2009.

\section{Fortuna crítica}

CALIL, Carlos Augusto e MACHADO, Maria Teresa (orgs.). Paulo Emílio: um intelectual na linha de frente. São Paulo: Embrafilme/Ministério da Cultura/Brasiliense, 1986.

CANDIDO, Antonio. "Paulo Emílio: a face política". In: Vários escritos. Rio de Janeiro: Ouro sobre Azul, 2006.

LEITE, Lígia Chiappini Moraes. "Paulo Emílio em banca de tese". In: Ensaios de Opinião, v. 6. Rio de Janeiro: Inúbia, 1978.

NEME, Mario (org). Plataforma da nova geração. Porto Alegre: Livraria do Globo, 1945.

SCHWARZ, Roberto. "Sobre três mulheres de três Pppês". In: O pai de família e outros estudos. Rio de Janeiro: Paz e Terra, 1978.

SOUZA, Gilda de Melo e. "Paulo Emílio: a crítica como perícia". In: Exercícios de leitura. São Paulo: Duas Cidades, 1980.

SOUZA, José Inácio de Melo. Paulo Emílio no Paraíso. Rio de Janeiro: Editora Record, 2002.

TAVARES, Zulmira Ribeiro. O trabalho de ser simples (sobre Paulo Emílio). São Paulo: IDART, 1974. 
TELLES, Lygia Fagundes. "Um retrato". In: Durante aquele estranho chá. São Paulo: Companhia das Letras, 2002.

\subsection{Décio de Almeida Prado: obra e fortuna crítica}

\section{Obra}

PRADO, Décio de Almeida. Apresentação do teatro brasileiro moderno, crítica teatral (1947-1955). São Paulo: Editora Perspectiva, 2001. . Exercício findo: crítica teatral (1964-1968). São Paulo: Editora Perspectiva, 1984.

. História concisa do teatro brasileiro - 1570-1908. São Paulo: Edusp, 1999. . “Teatro: 1930-1980” In: História geral da civilização brasileira, organização

Boris Fausto. São Paulo: Editora Bertrand Brasil, 1984.

- Peças, Pessoas, Personagens: o teatro brasileiro de Procópio Ferreira a Cacilda Becker. São Paulo: Companhia das Letras, 1993. . Procópio Ferreira. São Paulo: Editora Brasiliense, 1984.

. Seres, coisas, lugares: do teatro ao futebol. São Paulo: Companhia das Letras, 1997.

- Teatro em progresso, crítica teatral (1955-1964). São Paulo: Editora Perspectiva, 2002.

\section{Fortuna crítica}

ARÊAS, Vilma, AGUIAR, Flávio, FARIA, João R. (orgs.). Décio de Almeida Prado um homem de teatro. São Paulo: Edusp, 1997.

BERNSTEIN, Ana. A crítica cúmplice - Décio de Almeida Prado e a formação do teatro brasileiro moderno. São Paulo: Instituto Moreira Salles, 2005.

\subsection{Epistolografia}

BEM, Jeanne. "Le statut littéraire de la lettre". In: Les correspondances inédites. Textos reunidos por André Françon e Claude Goyard. Paris: Economica, 1984.

BECKER, Colette. 'Le discours d'escorte: l'annotation et ses problèmes (à propos de la correspondance de Zola)". Tradução de Claudio Hiro para uso didático na disciplina Epistolografia do Modernismo Brasileiro (IEB-USP), ministrada pelo 
Prof. Marcos Antonio de Moraes. In: Les correspondances inédites. Textos reunidos por André Françon e Claude Goyard. Paris: Econômica, 1984.

DIAZ, José-Luis. “Qual genética para as correspondências?”. Tradução de Cláudio Hiro e Maria Silvia Ianni Barsalini. In: Manuscrítica - Revista de crítica genética, $\mathrm{n}$. $15,2007$.

GALVÃO, Walnice Nogueira; GOTLIB, Nádia Battella (orgs.). Prezado Senhor, prezada Senhora: estudos sobre cartas. São Paulo: Companhia das Letras, 2000.

GRÉSILLON, Almuth. Elementos de crítica genética. Ler os manuscritos modernos.

Tradução de Cristina de Campos Velho Birck, Letícia Cobalchini, Simone Nunes Reis e Vincent Leclerq. Porto Alegre: Editora da UFRGS, 2007.

HAY, Louis. A literatura dos escritores: questões de crítica genética. Tradução de Cleonice Paes Barreto Mourão. Belo Horizonte: Editora UFMG, 2007.

KAUFMANN, Vincent. L'equivoque épistolaire. Paris: Éditions de Minuit, 1990.

LAJOLO, Marisa; ZILBERMAN, Regina. Das tábuas da lei à tela do computador: a leitura em seus discursos. São Paulo: Ática, 2009.

LEJEUNE, Philippe. O pacto autobiográfico: de Rousseau à internet. Organização de Jovita Maria Gerheim Noronha. Tradução de Jovita Maria Gerheim Noronha e Maria Inês Coimbra Guedes. Belo Horizonte: Editora UFMG, 2008.

MORAES, Marcos Antonio de. Orgulho de jamais aconselhar: a epistolografia de Mário de Andrade. São Paulo: Edusp/Fapesp, 2007. . "Epistolografia e crítica genética". Ciência e cultura (SBPC), v. 59, n. 1. São Paulo, Jan./Mar. 2007. . "Sobrescrito". Teresa revista de literatura brasileira 8/9. Programa de Pósgraduação em Literatura Brasileira, DLCV-FFLCH-USP, 2008.

TERESA. Revista de literatura brasileira 8/9 [epistolografia brasileira]. Programa de pós-graduação em literatura Brasileira. Departamento de Letras Clássicas e Vernáculas, FFLCH-USP/ IMESP/ 34 Letras, São Paulo, 2009.

\subsection{Perspectiva histórica e cultural}

ANDRADE, Mário de. Aspectos da literatura brasileira. São Paulo: Martins, 1978. O empalhador de passarinho. São Paulo: Martins, 1972. 
."Improviso do rapaz morto". In: Remate de Males. São Paulo: Livraria Martins Editora, 1980.

ANDRADE, Oswald. "Bilhete sobre fantasia". Revista Clima. São Paulo, n. 5, outubro de 1941. . O homem e o cavalo. São Paulo: Globo, 2005.

BOAVENTURA, Maria Eugênia. 22 por 22: a Semana de Arte Moderna vista por seus contemporâneos. São Paulo: EDUSP, 2010.

CANDIDO, Antonio. Teresina etc. Rio de Janeiro: Ouro sobre Azul, 2007. A educação pela noite e outros ensaios. Rio de Janeiro: Ouro sobre Azul, 2006.

. Formação da Literatura Brasileira - Momentos decisivos. Rio de Janeiro:

Ouro sobre Azul, 2007.

. Recortes. Rio de Janeiro: Ouro sobre Azul, 2004.

. O Discurso e a Cidade. Rio de Janeiro: Duas Cidades/ Ouro sobre Azul, 2004.

. Na sala de aula. São Paulo: Editora Ática, 2000.

. O albatroz e o Chinês. Rio de Janeiro: Ouro sobre Azul, 2004.

. Iniciação à literatura brasileira. Rio de Janeiro: Ouro sobre Azul, 2004.

COELHO, Ruy. Fantasia e a estética. In: Clima, n. 5, out. 1941.

GONÇALVES, Marcos Augusto. 1922: a semana que não terminou. São Paulo: Companhia das Letras, 2012.

LAFETÁ, João Luiz. 1930: a crítica e o modernismo. São Paulo: Duas Cidades; Ed. 34, 2000 .

LOBATO, Monteiro. A barca de Gleyre. São Paulo: Globo, 2010.

. "Cons. Rodrigues Alves”. In: Críticas e outras notas. São Paulo: Brasiliense, 1969.

"Paranoia ou mistificação (A propósito da exposição Malfatti)". In: Ideias de Jeca Tatu. São Paulo: Brasiliense, 1946.

LOPEZ, Telê Ancona (org.). Eu sou trezentos, eu sou trezentos e cincoenta (Mário de Andrade visto por seus contemporâneos). Rio de Janeiro: Agir, 2008.

LUCA, Tânia Regina de. Leituras, projetos e (re)vista(s) do Brasil (1916-1944). São

Paulo: Editora Unesp/Fapesp, 2011.

LUFT, Celso Pedro. Dicionário de literatura portuguesa e brasileira. Porto Alegre:

Editora Globo, 1979. 
MENEZES, Raimundo de. Dicionário literário brasileiro. Rio de Janeiro: LTC, 1978.

PONTES, Heloísa. Destinos mistos: os críticos do grupo Clima em São Paulo 19401968. São Paulo: Companhia das Letras, 1998.

QUEIROZ, Eça. Os Maias. São Paulo: Brasiliense, 1961.

ROBERTO, Pontual. Dicionário de artes plásticas no Brasil. Rio de Janeiro: Civilização Brasileira, 1969.

TAVARES, Zulmira Ribeiro. Café pequeno. São Paulo: Companhia das Letras, 1995.

\subsection{Dissertação}

MENDES, Adilson Inácio. Escrever cinema: a crítica cinematográfica de Paulo Emílio Sales Gomes (1935-1952). (Mestrado em Ciências da Comunicação).

\subsection{Artigos de jornal: entrevistas, matérias assinadas e não assinadas}

\section{Entrevistas}

CANDIDO, Antonio. "Entrevista concedida para o lançamento da Edição das Obras Completas de Paulo Emílio Sales Gomes”. São Paulo: CosacNaify, 2009.

GOMES, Paulo Emílio Sales. "Além de Mickey-Mouses". Entrevista concedida ao Diário da Noite (SP), 29.06.1935.

. "Esboça-se um novo movimento intelectual em São Paulo". Entrevista concedida ao Correio de S. Paulo, 21.06.1935.

. "Movimento pela democratização do ensino". Entrevista concedida ao Diário da Noite (SP), 13.05.1935.

\section{Matérias assinadas}

DURO, Cyro Sans. “Movimento”. Diário da Manhã (PR), 10.08.1935.

FERRAZ, Geraldo. “A revista Movimento”. Diário da Noite (SP), 03.08.1935.

GOMES, Paulo Emílio Sales. "Euclides da Cunha, Olavo Bilac e o Integralismo". Vanguarda Estudantil, setembro de 1935.

. “Contra o imperialismo e o latifúndio". A Platéia, 02.08.1935.

. "O drama das populações pobres, em cores vivas no interior do Estado". A

Platéia, 30.08.1935. 
. “O Moleque Ricardo e a Aliança Nacional Libertadora”. A Platéia, 21.09.1935.

G. "Movimento". Para coluna Sociais do Diário de S. Paulo, 30.07.1935.

\section{Matérias não assinadas}

“Movimento". Diário da Noite (SP), 22.07.1935.

“Movimento". Correio de S. Paulo, 23.07.1935.

"Publicações". O Estado de S. Paulo, 25.07.1935.

"Movimento acaba de aparecer em S. Paulo, essa revista cultural". A Gazeta, 25.07.1935

"Movimento". A Platéia, 07.1935

"Materialismo histórico". Para seção A margem dos fatos da Folha da Noite, 29.07.1935.

“Desafiado para um duelo...”. Diário da Noite (SP), 12.08.1935.

"Duelo a Bofetões". O Globo (RJ), 13.08.1935.

“Rasgou a revista e está convidado a um duelo a bofetões". O Jornal (RJ), 13.08.1935.

“Desafiado para um duelo a tapa”. Diário de S. Paulo, 13.08.1935.

“Ainda o caso da revista Movimento”. Diário da Noite (SP), 13.08.1935.

"Realizou-se ontem a primeira reunião para tratar dos direitos da mocidade". A Platéia, 18.09.1935.

\subsection{Periódicos}

Revista Clima. São Paulo, n. 5, outubro de 1941.

Movimento - revista do presente que enxerga o futuro. São Paulo, n. 1, julho-agostosetembro de 1935.

\section{Anexo}


4.1. Movimento-revista do presente que enxerga o futuro

- Capa

- Sumário

- Página de rosto

- "Manifesto"

- "Roberto" (Mário de Andrade)

- "Trecho de vida" (Hag Reindrahr)

- Resenha Patrocínio (DAP)

- Contracapa

\subsection{Cartas}

- 20 de junho de 1935 (primeira página da carta) / PE

- Julho de 1935 (carta sem data) / DAP

- 13 de agosto de 1935 / PE 